Portland State University

PDXScholar

1971

\title{
Predictors of placement from a juvenile detention facility
}

Diane C. Brock

Portland State University

Anneva E. Lenz

Portland State University

Ann C. Houston

Portland State University

Richard R. Munn

Portland State University

David F. Parks

Portland State University

Follow this and additional works at: https://pdxscholar.library.pdx.edu/open_access_etds

Part of the Social Control, Law, Crime, and Deviance Commons, and the Social Work Commons Let us know how access to this document benefits you.

\section{Recommended Citation}

Brock, Diane C.; Lenz, Anneva E.; Houston, Ann C.; Munn, Richard R.; and Parks, David F., "Predictors of placement from a juvenile detention facility" (1971). Dissertations and Theses. Paper 1553.

https://doi.org/10.15760/etd.1552

This Thesis is brought to you for free and open access. It has been accepted for inclusion in Dissertations and Theses by an authorized administrator of PDXScholar. Please contact us if we can make this document more accessible: pdxscholar@pdx.edu. 
AN ABSTRACT OF THE THESIS OF Diane C. Brock, et al. for the Master in Social Work presented May 14, 1971.

APPROVED BY MEMBERS OF THE THESIS COMMITTEE:

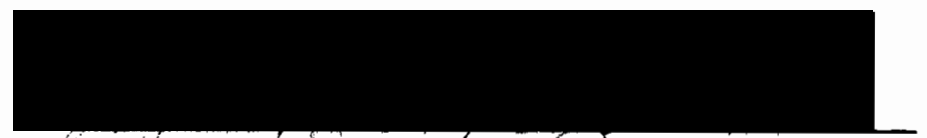

Már thá N. Ozawa, Ghairman

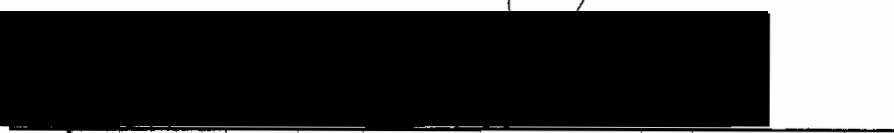

Quentin D. Clarkson

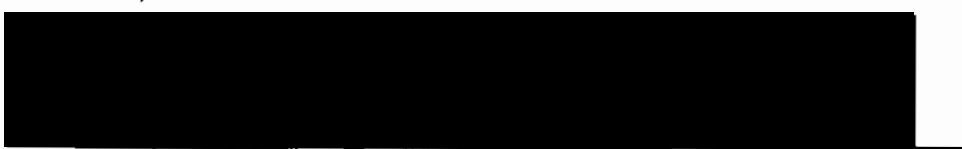

L. Jay Conpqd

The purpose of this project was to determine whether certain personal, socioeconomic, and court-related factors a re significantly related to the differential placement of delinquent and dependent children from the detention facility at the Donald E. Long Home. A stratified random sample was composed of 173 placements of children who were held in detention after a preliminary hearing.

The review of literature revealed that little systematic information is known regarding the placement process as it is related to differential placement of children from a detention facility.

A code sheet was developed for recording the information in the children's records maintained by the court. Fourteen variables were ultimately selected for analysis of their relationship to differential placement. These variables were subjected to three statistical 
approaches; a descriptive analysis of the random sample, testing of the significance of each variable to the alternatives in placement by either Chi square or analyses of variance, and testing of several variables in combination by discriminant function.

This study was limited by the fact that only demographic variables were tested. Although three individual variables were found to have a high degree of significance in relation to placement, the data as produced within the scope of this research project does not provide an effective placement profile. The need for additional research in the area of the differential placement process is clearly indicated. Suggestions are made for future research. 


\section{PREDICTORS OF PLACEMENT FROM A JUVENILE DETENTION FACILITY}

by
DLANE C. BROCK
ANNEVA E. LENZ
ANN C. HOUSTON
RICHARD R. MUNN
DAVID F. PARKS

A thesis submitted in partial fulfillment of the requirements for the degree of

MASTER OF SOCIAL WORK

Portland State University

1971 
TO THE OFFICE OF GRADUATE STUDIES:

The members of the Committee approve the thesis of

Diane C. Brock, et al. presented May 14, 1971 .

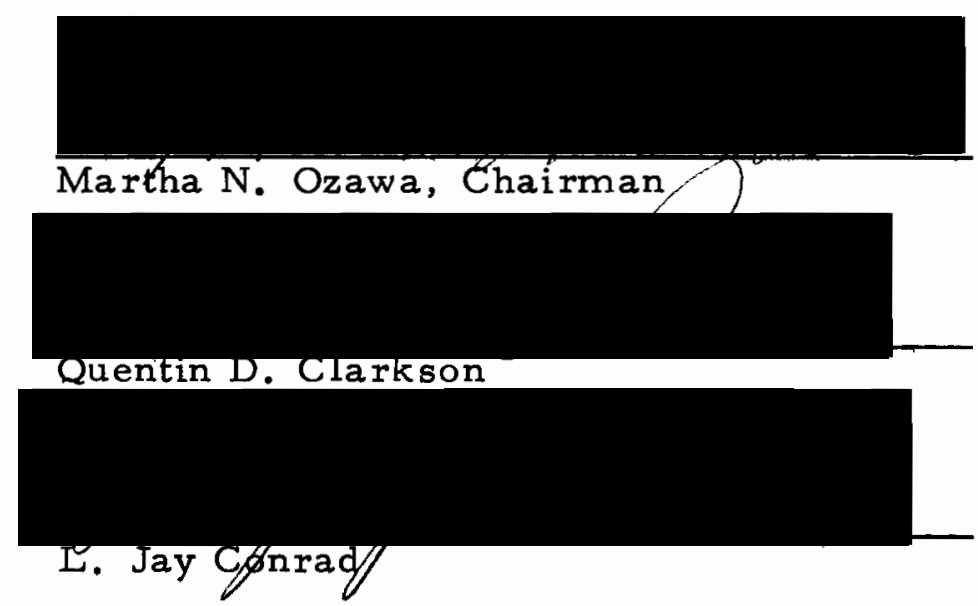

APPROVED:

Gordop/Hearn, Dean of School of Social Work

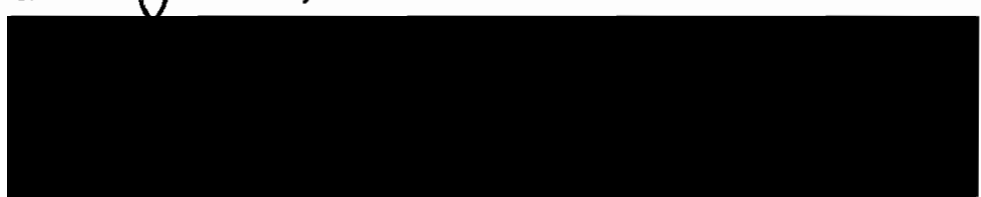

David T. Clark, Dean of Graduate Studies

May 17,1971 


\section{ACKNOW LEDGMENTS}

Sincere appreciation is exiended to the many individuals who assisted the writers in the preparation of this thesis.

We wish to express our thanks to Mr. Robert Dahl, Supervisor of Counseling Services, Multnomah County Juvenile Court, for allowing us to use the resources of the department for this project. Special thanks are extended to the clerical staff at the Multnomah County Juvenile Court for their help in facilitating the gathering of the data for this thesis.

We are particularly grateful to Dr. Martha N. Ozawa, Thesis Chairman, and Dr. Quentin D. Clarkson, Thesis Committee Member, who have spent considerable time guiding us through the completion of the thesis.

Special acknowledgment is given to Mr. L. Jay Conrad, Thesis Committee Member, without whose advice and encouragement we would not have undertaken this project. We are indebted to Mr. Conrad for his untiring commitment to this group and for his unwavering standards of excellence.

Finally, our special thanks go to David Brock who generously came to our aid and spent long hours proofreading key punch cards. 
TABLE OF CONTENTS

PAGE

ACKNOW LEDGMENTS .................... . . . . . . . . . .

LIST OF TABLES $\ldots \ldots \ldots \ldots \ldots$ vii CHAPTER

I INTRODUCTION .................. 1

General Statement of the Problem ...... 1

Historical and Philosophical Background

of the Juvenile Court System ....... 4

Historical Developments ......... 4

Philosophical Viewpoint ........ 7

An Ideology and Its Challenges ...... 8

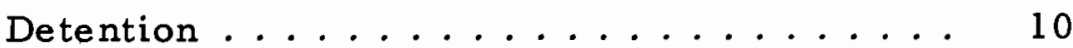

The Decision-Making Process ....... 13

The Intent of This Study ......... 16

II REVIEW OF THE LITERATURE ......... 18

Introduction ................ 18

Alternatives in Placement......... 20

Introduction ............... 20

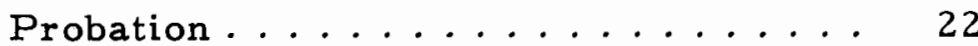

Foster Home Placement ........ 25

Institutional Placement........ 28

Summary .............. 31

Selected Variables............... 33

Introduction .............. 33

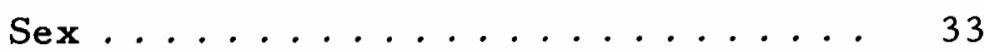

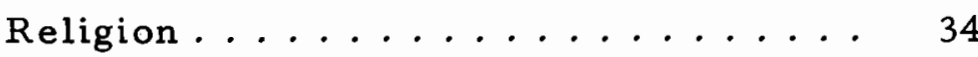

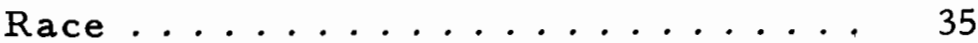


Number of Siblings.......... 36

Marital Status of Natural Parents ... 37

Living Arrangement of Child Prior to

Detention .............. 38

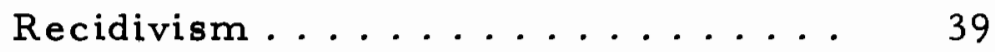

Reason Referred ........... 40

Family Income ............ 41

School Status and School Attainment. . 42

Age ................. 43

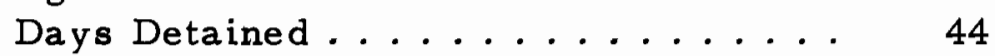

Counselor ................. 45

Summary .................... 47

III. METHODOLOGY ................. 48

Introduction $\ldots \ldots \ldots \ldots \ldots \ldots$

Population Description ........... 49

Collection and Organization of Data .... 50

Stratification of Population ........ 51

Random Sample .............. 55

Individual Unit Data Collection ..... 55

Preliminary Survey ........... 56

IV. DATA ANALYSIS AND INTER PRETATION

OF FINDINGS .............. 64

Introduction ................... 64

Descriptive Data................ 65

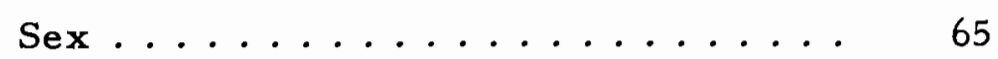

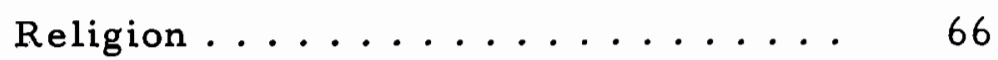

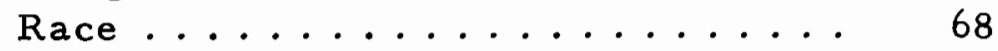

Number of Siblings ............. 69

Marital Status of Natural Parents.... 71

Living Arrangement of Child Prior to Detention .......... 71 
CHAPTER

PAGE

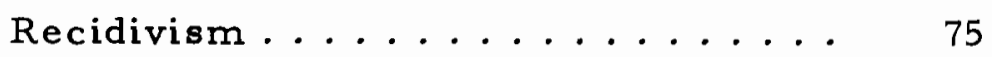

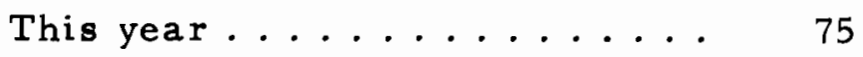

Prior years ................. 76

Reason Referred ........... 77

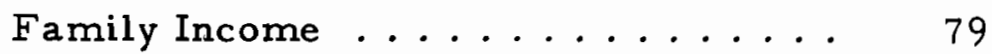

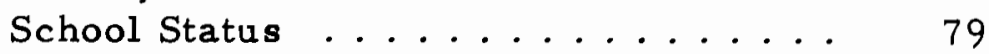

School Attainment .......... 82

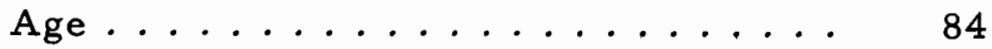

School Attainment, Age, and Days

Detained: Pooled Information .. 86

Days Detained ............ 87

Discriminant Function Analysis ...... 89

V. CONCLUSIONS AND IMPLICATIONS FOR

FURTHER STUDY ................ 94

Introduction .................. 94

Conclusions .................... 94

Implications for Further Study . . . . . . 97

A LIST OF WORKS CONSULTED ................. 99

APPENDIX A INFORMATION ENTERED ON THE

RECEIVING LEDGER OF THE

DONALD E. LONG HOME ....... 107

APPENDIX B CODE FOR JUVENILE DETENTION

HOME LEDGER RECORD ....... 108

APPENDIX C INFORMATION ENTERED ON THE

CHILDREN'S BUREAU'S JUVENILE

COURT STATISTICAL CARD .....

APPENDIX D INFORMATION ENTERED ON THE

MULTNOMAH COUNTY JUVENILE

COURT FACE SHEET .......... 115

APPENDIX E CODE SHEET \#1................ 116

APPENDIX F CODE SHEET \#2 ................. 119

APPENDIX G FREQUENCY TABULATION AND

PERCENTAGE DISTRIBUTION

TABLES OF INDEPENDENT VARI-

ABLES LISTED BY GROUP ....... 123

APPENDIX H TABLES OF DISCRIMINANT FUNCTION

WITH GROUP MEANS .......... 138 


\section{LIST OF TABLES}

TABLE

PAGE

I Population Placement Distribution ....... 50

II Placement Alternatives and Numbers of

Individual Placements in Each Group .... 54

III Summary of Data Frequency Tabulation of

Inde pendent Variables .......... 57

IV Frequency and Percentage Distribution of Sex

By Placement .................... 66

V Frequency and Percentage Distribution of

Religion By Placement ......... 67

VI Frequency and Percentage Distribution of

Race By Placement ........... 69

VII Frequency and Percentage Distribution of

Number of Siblings By Placement . . . . 70

VIII Frequency and Percentage Distribution of

Marital Status of Natural Parents By

Placement .................. 72

IX Frequency and Percentage Distribution of

Living Arrangement of Child Prior to

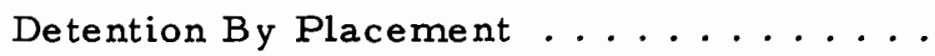


$\mathrm{X}$ Frequency and Percentage Distribution of

$$
\text { Recidivism This Year By Placement.... }
$$

XI Frequency and Percentage Distribution of

Recidivism in Prior Years By Placement..

XII Frequency and Percentage Distribution of

Reason Referred By Placement .......

XIII Frequency and Percentage Distribution of

Family Income By Placement ....... 80

XIV Frequency and Percentage Distribution of

School Status By Placement.........

XV Frequency and Percentage Distribution of

School Attainment By Placement ..... 93

XVI Analysis of Variance: School Attainment .... 84

XVII Range of Age Representation By Group ..... 84

XVIII Analysis of Variance: Age ......... 86

XIX Correlation Matrix: School Attainment, Age and Days Detained .............. 86

XX Range and Median of Days Detained By Group . . $\quad 87$

XXI Analysis of Variance: Days Detained ...... 88 
XXII Discriminant Function Analysis of Five

Variables: Reason Referred, Recidivism

Prior Years, School Status, Marital Status

of Natural Parents, Age ......... 90

XXIII Discriminant Function Analysis of Seven

Variables: Religion, Living Arrangement

of Child Prior to Detention, Recidivism

Prior Years, Reason Referred, School

Status, Age, Marital Status of Natural

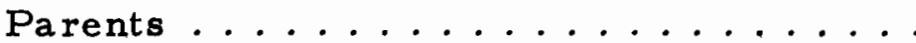

XXIV Discriminant Function Analysis of Five

Variables: Age, Number of Siblings,

School Attainment, Family Income, Days

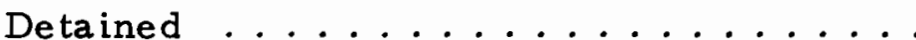

XXV Discriminant Function Analysis of Eight

Variables: Age, Sex, Race, Number of

Siblings, School Attainment, Family

Income, Days Detained, School Status....

XXVI Frequency Tabulation and Percentage Distribu-

tion of Independent Variables for Group I:

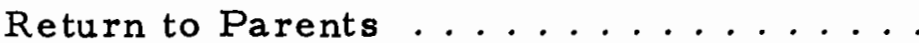


XXVII Frequency Tabulation and Percentage Distribution of Independent Variables for Group II:

Foster Home Care ............. 128

XXVIII Frequency Tabulation and Percentage Distri-

bution of Independent Variables for Group

III: Treatment Institutions ......... 132

XXIX Frequency Tabulation and Percentage Distri-

bution of Independent Variables for Group

IV: Correctional Institutions ........ 135

XXX Discriminant Function of Five Variables

With Group Means ............. 139

XXXI Discriminant Function of Seven Variables

With Group Means ............ 140

XXXII Discriminant Function of Five Variables

With Group Means ............ 141

XXXIII Discriminant Function of Eight Variables

With Group Means ............. 142 


\section{CHAPTER I}

\section{INT RODUCTION}

\section{GENERAL STATEMENT OF THE PROBLEM}

Juvenile courts, established during a period of great social reform, held out the promise that children in trouble with the law would be treated differently from adults in criminal courts (Tenney, May, 1969, p. 101). They were to receive the attention of experts who would adhere to a philosophy of treatment and rehabilitation rather than punishment. A review of the juvenile court system indicates, however, that these courts have frequently fallen far short of this textbook ideal. "At its worst the court has become a placement agency for state institutions and is called upon only when such placement is needed" (Rinck, 1959, p. 1126). Further study reveals that juvenile courts, as other social agencies, have expended great csfort in gathering information about a child on the assumption that the more that is known, the better the treatment plan. It appears, however, that this information is compiled without knowing whether it was needed or useful in the treatment process (Terry, July, 1967; Briar, April, 1963; Sauber, August, 1967).

Certain questions are the reby raised. Not all children who come to the attention of juvenile courts go to state institutions. Is it 
possible, on the basis of the material in a child's record to predict where he will be placed? What factors influence his placement when he comes to the attention of a juvenile court? Is there a certain constellation of factors which further affects his placement?

Answers to these questions should be helpful in all fields of child welfare. For example, if the correlates of differential placement outcome are known, the placement for a specific child can be determined. Such data could provide evidence to either substantiate or dispute presently employed placement methods.

The purpose of this exploratory study is to determine whether certain personal, socioeconomic, and court-related factors are significantly related to the differential placement of delinguent and dependent children from detention facilities. The study was conducted at the Multnomah County Juvenile Court and Donald E. Long Home, Portland, Oregon, by five graduate students from the School of Social Work, Portland State University, assigned to the Court for a field practicum. Interest in the problems of differential placement of delinquent and dependent children was generated by observations of the juvenile court system and by conversations with the professional staff who expressed concern about the seemingly haphazard way in which children were being placed.

This study has been limited to examining certain demographic factors found within a child's official court record. It was further 
limited to a specific population within the Multnomah County Juvenile Court setting. The majority of children coming to the attention of the court have no formal hearing before a judge and are not held in detention facilities. The majority remain in their parents' custody and in their own homes. Consequently, it was decided to limit the population of this study to those children who remained in detention facilities following a preliminary hearing. The preliminary hearing determines by judicial decision whether the child's problem is sufficient to hold him in detention until adjudication or disposition of his case. It is at this point in a child's experience with the juvenile court that maximum efforts should be initiated to find the most suitable placement for him. Charnley (1955, p. xiv) dramatically describes the traumatic effects of placement upon children in substitute care:

The social worker who has ridden in her car beside a hundred children who are leaving their pasts behind and moving into a threatening new world does not need to have it explained to her that this is terrifying to a small client. And the social worker who has listened to a hundred angry adolescents who are still trying to recapture a place in their own homes that they lost years ago will know that the decision to place a child without a clear and reasonable expectation of how it will all end is a grave one.

Initially, the historical and philosophical background of the juvenile court system will be examined, followed by a discussion of decision-making problems. Thereafter, variables selected for further examination in this research project, most of which are found to be significant in the literature as well as several which are of 
particular interest to the researchers, will be expostulated. Concomitantly, the alternatives in placement will be discussed. An explanation of the research design will follow in order to provide full comprehension of the findings. Conclusions will be drawn and recommendations will be made. The authors have endeavored to contribute constructive knowledge to the field of child welfare and more specifically to the Multnomah County Juvenile Court, whereby child placement may be better understood and its process made less traumatic for children.

\section{HISTORICAL AND PHILOSOPHICAL BACKGROUND OF THE JUVENILE COURT SYSTEM}

\section{Historical Development}

The historical development of the juvenile court system is obscured by time. The roots of our laws applicable to children and young people are found in English common law (Tenney, May, 1969, p. 102-3). Research in this a rea substantiates that English common law in many instances provided for differential treatment of persons under a certain age. History disclosed that children really stood in a dual role in the eyes of English law. In the words of Sussmann and Baum (1968, p. 6):

The modern juvenile court is, in the spirit of its approach to the delinguent child, much like the old Chancery courts which protected helpless children, and in part has its origin in the Chancery idea. Yet we must recognize that basically 
the courts' jurisdiction over delinquent children has its origins in the criminal law, and represents an experiment in law and judicial method aimed at relieving juveniles from the rigidity and severity of that law. In this connection, the theory that children under a certain age who break the law should be treated differently from adult criminals and in a special court, is somewhat analogous to the old common-law rule that children under a certain age would not be held criminally responsible.

While early English colonists brought a dual concept of law with them to America, it was not generally utilized.

During the nineteenth century a movement was initiated in this country to protect young offenders in criminal proceedings. The first state reformatory for juvenile offenders was established in New York in 1825 followed by the founding of similar institutions in Pennsylvania in 1828 and Massachusetts in 1847. As early as 1869 , Massachusetts provided separate hearings for children and by 1880 had introduced a separate probation system. New York, Indiana, and Rhode Island also followed suit with laws providing for separate hearings. Probation systems were implemented in New York, Indiana, and Illinois soon thereafter. While these reforms distinguished between juvenile and adult offenders, they did not yet embody the basic concept that "children who break the law are not to be treated as criminals, but as wards of the state, in special need of care, protection, and treatment" (Sussmann and Baum, 1968, p. 3-4).

A major change occurred when the world's first juvenile court was established in Cook County, Illinois in 1899. The change 
eliminated arrest by warrant, indictment, trial by jury, and other features common to adult criminal proceedings. The law provided for a distinct way of handling children in trouble utilizing the principle of parens patriae; that is, the state in the form of the juvenile court assumes the responsibilities of the parents who have defaulted in the se responsibilities. At the same time, the law introduced the use of a juvenile court judge, the juvenile courtroom and the maintenance of separate records (National Council on Crime and Delinquency, $1963, p \cdot 2-3)$.

It is evident that the juvenile court was established in response to the growing concern over the callous, indifferent treatment of children accused of criminal activity. H. H. Lou (1927, p. 1) directs attention to other important social forces which signaled an accelerated interest in the handling of juveniles:

The history of modern treatment of juvenile offenders had its rise during the period of the industrial revolution and of the religious and moral revival at the beginning of the nineteenth century. It is more or less directly connected with the factory legislation in favor of women and children.

Legislation regulating working conditions for children established a precedent that children were to be treated differently from adults under the law and pointed the way for further laws regulating the care of children in other areas (Tenney, May, 1969, p. 104).

Since 1899 , modifications of the earlier views as to how the juvenile court is to function have been extensive. The revolution that 
has taken place represents more than a change in the handling of children: it marks a new social attitude toward the problems of the young. In the spirit of this reform, the assumption that juvenile courts are judicial tribunals that deal in special ways with children's cases has been prevalent:

They differ from adult criminal courts in a number of basic respects, reflecting the philosophy that erring children should be protected and rehabilitated rather than subjected to the harshness of the criminal system. Thus, they substitute procedural informality for the adversary system, emphasize investigation of the juvenile's background in deciding upon dispositions, rely heavily on the social sciences for both diagnosis and treatment, and in general are committed to rehabilitation of the juvenile as the predominant goal of the entire process (The President's Commission on Law Enforcement and Administration of Justice, 1967, p. 1).

The essential philosophy of the juvenile court, and of the other specialized courts handling youthful offenders is one of "individualized justice" (Pound, 1949).

$\underline{\text { Philosophical Viewpoint }}$

Individualized justice has been difficult to achieve. It has been suggested that to become a fair and fully effective tribunal operating for the general welfare, the juvenile court should have the following:

1. A judge and a staff identified with and capable of carrying out, a non-punitive and individualized service.

2. Sufficient facilities available in the court and community to insure:

a. that the dispositions of the court are based on best available knowledge of the child. 
b. that the child if he needs care and treatment receives these through facilities adapted to his needs and from persons properly qualified and empowered to give them.

c. that the community receives adequate protection.

3. Procedures that a re designed to insure that two objectives are kept constantly in mind, these being:

a. the individualization of the child and his situation.

b. the protection of the legal and constitutional rights of both parents and child (Eldefonso, 1967, p. 166).

Although some courts have been able to conform to the aforementioned criteria, others, particularly those in rural areas, have not been able to develop the necessary facilities (Carr, 1949, p. 33). Still others have been unable to conceptualize a non-punitive approach to justice or have over-emphasized the protection of the individual's rights (Eldefonso, 1967, p. 166-7).

\section{An Ideology and Its Challenges}

The American concept of a juvenile court has developed in a haphazard fashion for over a half-century; yet, over the years the highest courts of many states have indicated approval of the basic: concept of the juvenile court (Weinstein and Goodman, October, 1969, p. 482). This concept has additionally been stabilized by general precepts advanced by the U. S. Children's Bureau and the National Council on Crime and Delinquency. Nevertheless, juvenile courts have been subjected to local influences and pressures. Imperfections arising from these influences and pressures have been brought to the attention of the United States Supreme Court whose decisions have 
subsequently been interpreted in varying and confusing fashion.

In the matter of Kent (In re Kent, 383, U. S. 541, 1966) a juvenile court judge was found to have committed a procedural error. The decision was obviously intended to provide a sharp reminder as to the objectives of the juvenile court. Logically, the consequences of this precautionary advice should have been an abrupt re-evaluation of performance to insure competency in the future. Instead, there developed a preponderance of demands to fashion the juvenile court after an adult criminal court and extend all constitutional rights and procedures afforded adults in criminal courts to children in juvenile courts. The implication of this proposal is that children have been exposed to the most outrageous forms of treatment by malicious judges without legal restraints (Weinstein and Goodman, October, 1969, p. 482).

In the matter of Gault, the Supreme Court made the juvenile court proceedings adversary in nature when a child is declared a delinquent and sentenced to an institution (Coyne, May, 1969, p. 45). This decision "imposed due process requirements in the adjudicary stages" and implies that "the avowed objective of treatment and rehabilitation no longer justifies substantial deprivation of constitutional rights" (Foster, May, 1969, p. 143).

The implications of the se decisions are not yet clear. Only the future will tell if they were advances for juvenile rights or were 
a return to the same procedures and consequences given adults (Shafer and Knudten, 1970, p. 374).

\section{DETENTION}

Children coming to the attention of a juvenile court are usually classified as delinquent or dependent. All states have laws which might vary in wording yet have a common core of agreement. A child is considered to be delinquent if he violates a law or ordinance. Most states also include acts or conditions which apply to children only, such as incorrigibility, beyond the control of a parent or guardian, or running away (Dunham, 1966). Most juvenile courts, in addition, have jurisdiction over neglected or abused children. Oregon, in an attempt to be non-punitive does not use the word delinquent in its juvenile court code (Oregon Revised Statutes, 19591963, 419, 476). According to this code, a child under eighteen is said to be within the jurisdiction of the court:

(a) Who has committed an act which is a violation, or which if done by an adult would constitute a violation, of a law or ordinance of the United States or a state, county or city; or

(b) Who is beyond the control of his parents, guardian or other person having his custody; or

(c) Whose behavior, condition or circumstances are such as to endanger his own welfare or the welfare of others; or

(d) Who is dependent for care and support on a public or private child-caring agency that needs the services of the court in planning for his best interests; or

(e) Either his parents or any other person having his custody have abandoned him, failed to provide him with the 
support or education required by law, subjected him to cruelty or depravity or failed to provide him with the care, guidance and protection necessary for his physical, mental or emotional well-being; or

(f) Who has run away from his home.

Nevertheless, the words, "delinquent" and "dependent", are used widely in the literature on juvenile delinquency and child placement. To conform to this trend, this study will use these terms.

A child is often placed in a detention facility while waiting for a disposition by the juvenile court. "Properly speaking, detention refers to temporary custody or care during the period between the child's apprehension on a delinquency charge or for an alleged delinquent act, and the final disposition by the juvenile court" (Sussmann and Baum, 1968, p. 32). Children are also held in detention facilities under protective custody when there are no other facilities for them. In most states, a child comes before a judge or hearing officer within forty-eight hours after he is detained. During this preliminary hearing it is decided whether or not he has been legally held and whether or not he should be held further pending final disposition of his case. As stated earlier, most children are at this time released to their parents or guardians.

Ideally, a juvenile detention facility serves the purpose of separating the juvenile from the adult offenders, thus lessening the possibility of adverse influence (Sussmann and Baum, 1968, p. 33). Ideally, a detention home should be used for temporary care under 
the following circumstances:

Children who are likely to run away during the time their case is being studied.

Children who are almost certain to commit an offense dangerous to themselves or to the community before a disposition is made, if released.

Children who must be held for other institutions or jurisdictions.

Children for whom secure custody is necessary while psychological or psychiatric studies are being made. (Juvenile Court Counselor's Manual, p. 8-1).

Detention should be as positive an experience as possible and should provide for the educational, medical, and recreational needs of a child as well as provide for adequate physical care and safety (Lundberg, 1947, p. 338).

While it is recognized there is a need for some form of detention facility, these facilities are often used for other purposes than those stated above. Children are sometimes placed in detention without the police or court officials determining whether the children could have safely remained in their own homes until their cases were heard (Lundberg, 1947, p. 338-9). Often detention facilities are used for short-term disciplinary treatment or "jail therapy". In this case, the emphasis is upon punishment by detaining the child rather than upon assessing the individual needs of the child or evaluating the effects of such placement on the child (Lundberg, 1947, p. 342). Children are also often kept in detention facilities after a court hearing for varied reasons including the already discussed lack of 
resources. Lundberg (1947, p. 337) reports that the child sometimes remains in detention until it is convenient for the official to take him to an institution or other type of placement. Sussmann and Baum (1968, p. 41) state that "detention is not and can never be a substitute for casework treatment of delinquent children which must be done with the family and the community."

\section{THE DECISION-MAKING PROCESS}

The social investigation, or social study, is the basic tool used by the juvenile court in the dispositional process. It is completed by the juvenile probation officer, or counselor. Investigation into the child's social history is usually required by law and is one of the major functions of the counselor. When applicable, information pertinent to the etiology of the problem and present conditions is obtained from other social or public agencies. The social study usually includes an inquiry into the child's family, neighborhood, school, and other circumstances. Information is also obtained from the child himself (Tappan, 1949, p. 187).

There are problems surrounding the use of the social study in the decision-making process. Kahn (1953, p. 170) discusses the case study in the probation department. He states that too often the case study is made out routinely by an investigator rather than by a person who sees himself as a helper. The inadequate case study results in 
poor planning for many children, trial and error procedures, and questionable dispositions by the court or the counselor. Kahn (1953, p. 222) emphasizes that the failure of the case study is actually the failure of the person doing the study. Briar (April, 1963, p. 161), in studying the decision-making process in foster home placements, voices much the same concern:

There is no doubt that the radical changes being introduced in the lives of children as a result of clinical decisions made by social workers engaged in foster care placement can have profound effects, both for good and ill, on subsequent personal and social development of these children.

Systematically we know next to nothing about how the childplacement worker makes these decisions. More generally, we know very little about how social workers in all fields of practice form their clinical judgments and treatment decisions.

Kahn (1953, p. 223) discusses the need for better trained probation officers, implying that poorly trained workers do not use imagination in making a treatment plan. He concludes that "the improper institutionalization of children costs the city and state more in the course of a year than would adequate salaries for probation officers."

Practice in social investigation in the court setting is analogous to good casework investigation, which is to consider the individual child and his problem in his present situation. In reality, lack of time, personnel, and training result in much more cursory social studies than good social agencies demand (Tappan, 1949, p. 187). 
Since the social study should include at least a treatment plan, it carries serious weight in the matter of institutional commitment. Any recommendation for commitment should the refore be based on a judgment that commitment is indeed the preferred disposition. (National Council on Crime and Delinquency, 1965, p. 2.4).

Tappan (1949, p. 188) concurs, concluding his discussion about social studies with the following comment; "That the information procured in very inadequate investigations should be accepted as an important, often major, basis of adjudication in progressive courts is an amazing product of good intentions in sociological experimentation."

In spite of the problems and inadequacies of the social studies they are still the best tool available to the court in arriving at decisions and making dispositions. They are also valuable sources of information for research. Many studies have been done using case records and social studies as the source of raw data (Carter, July, 1967; Gross, July, 1967; Terry, July, 1967; Briar, April, 1963;

Fanshel, April, 1963; Matek, July, 1964; Jaffe, December, 1967; and Foy, September, 1967).

When a child is held in a detention facility beyond the preliminary hearing, the question uppermost in the court counselor's mind is, "Where does he go from here?" If the counselor has adequately studied and diagnosed a child's problem and situation, he is then better prepared to examine the alternatives in placement and to 
recommend the one which meets the needs of the individual child.

\section{THE INTENT OF THIS STUDY}

The philosophical framework for this study has been established. The essential philosophy of juvenile courts is that of individual justice. The decision-making process involves the social work practices of considering the child and his problem in his particular situation and evolving a treatment plan from these considerations. Ideally, the treatment plan should be an individualized one regardless of the placement setting. There should be no hierarchy of placement from probation for a first offense, progressing to a foster home, to a treatment-oriented institution, ending in a correctional institution for many offenses. Even institutional placement should be by choice, not by default.

Obstacles to achieving the goal of individualized justice, or treatment, have been indicated. It is not the intent of this study, however, to explore these obstacles. This research project is limited to the examination of certain demographic factors as reported in a child's court record. The choice of these factors has been indicated by a review of the literature and by the researchers' own interests. Other factors, such as an exploration of the counselor's background and judgment may also be influential but a re not 
herein examined.

The intent of this study is to identify those variables which correlate significantly with the alternatives in placement and to determine what patterns, or constellations, of variables are associated with a particular placement choice. To state the problem another way, on the basis of material recorded in his court file, how well can one predict the differential placement of a particular child upon leaving a juvenile court detention facility? If the specific placement for a particular child can be predicted on the basis of certain demographic factors, the placement procedures can be modified to concentrate on these factors. Re-examination of recording procedures used in completing social histories is a hoped-for end. Certainly the misuse of the counselors' time by recording superficial data is of significance. The ability to predict the differential placement for a child is also related to the planning of social services. If certain types of children are sent to certain types of placement, then, there should be developed adequate resources for each group of children. Additionally, the actual use of the present facilities can be examined in light of their stated function. The aspect of the misuse of resources is a grave one, especially at a time when communities a re finding it difficult to provide adequate social services. Finally, this study can hopefully illuminate the threshhold for future research. 
CHAPTER II

REVIEW OF THE LITERATURE

\section{INT RODUCTION}

The problems of differential placement of children in the juvenile court setting are part of the larger concern for the welfare of children. A common historical background is shared. During the period of social reform in the nineteenth century when juvenile courts were established, new methods of child care emerged. These were related in turn to greater problems such as health care, education, neglect of children, and juvenile delinquency. In discussing juvenile delinquency Shafer and Knudten (1970) have delineated four major approaches to the problem which have influenced society's thinking and actions. The influence of the se approaches is also seen in all areas of child welfare and must be kept in mind when one studies the myriad problems involved.

The legalistic approach unites juvenile delinquency with the greater problem of crime as well as the problem of safeguarding the civil rights of offenders. It is primarily interested in the offense and "the act and not the actor is the main subject of concern" (Shafer and Knudten, p. xv). On the other hand, the social welfare approach sees the whole child in his social setting and thus "encourages the widest 
possible examination of each aspect of a child's development" (Shafer and Knudten, p. xvi).

The psychological approach focuses on the development of the child's personality and seeks answers to the cause of his problems as well as solutions in an examination of his psychic development. Still, the sociological approach emphasizes the social aspects of a child's life including cultural factors and relates his problems to the major ones of poverty, urban crisis, and racial oppression (Shafer and Knudten, p. xvi).

These views appear to be the basis and justification for recording numerous variables in a child's social history. As already stated, this study is limited to testing the utility of certain demographic factors found within the child's court record. The specific independent variables selected were sex, religion, race, number $\underline{\text { ref }}$ siblings, marital status of natural parents, living arrangement of child prior to detention, recidivism, reason referred, family income, school status, school attainment, age, days detained, and counselor. The criteria for the inclusion of these variables were that (1) a variable was found to be either relevant or controversial in the literature, and (2) a variable was of special interest to the researchers on the basis of their own past experiences and observations.

The review of literature concerning these variables was complicated by the previously mentioned approaches. It was necessary 
to search out pertinent information in all four disciplines. These approaches also had to be kept in mind in determining the significance of individual studies. Additionally, it was found that there was a lack of research concerning the specific problem of differential placement of children from juvenile detention facilities. It was necessary to examine the problem from all aspects. Thus, studies of counselors, or social worker's, decision-making processes were reviewed, as were investigations of children in different types of placement and studies of individual variables. Of particular importance was the exploration of the vast research into the causes of juvenile delinquency and dependency, for as Tappan (1949, p. 72) warns:

- . treatment needs to be based upon as exact an examination as can be secured by probing clinical investigation of the forces that contributed to unadjustment: constitutional, psychological, and social.

Treatment also involves knowledge of the choices and resources available to a particular child. Therefore, it is pertinent to discuss the dependent variable, alternatives in placement, for a child ready to leave a juvenile court detention facility. Examination of the selected independent variables will then follow.

\section{ALTERNATIVES IN PLACEMENT}

Introduction

After a child's case is presented to the judge, and after he 
has decided that the juvenile court has jurisdiction over the child, he is then faced with the decision of what to do with the child. In most states juvenile court judges have four major courses of action in the disposition of a case. The se are (1) dismissal or discharge of the child, (2) probation and supervision of the child while he remains in his own home, (3) foster home placement, and (4) commitment to an institution (Sussmann and Baum, 1968).

Two of the se alternatives allow the child to remain in his own home and two involve removal to some form of substitute care, which is "a change in the legal custody of the child" (Kadushin, 1967, p. 354). In the literature, placement usually implies removal of the child from his home. In this study, however, the concern is what happens to a child when he leaves the detention home. It is necessary to find a place or situation for him. Thus, for the purpose of this study, returning to one's home is considered to be a choice of placement. In most cases, when this happens, a child is usually placed on probation. In addition, this study makes a distinction between treatmentoriented institutions and those which are primarily correctional ones. It has already been stated that juvenile courts are to be treatment agencies. Placement of a child should be "a tool whose use is arrived at diagnostically and whose handling involves the utmost thought and care" (Charnley, 1955, p. xiii). Kadushin (1967) emphasizes the traumatic effects on children of placement in substitute care 
and warns against its indiscriminate use. Not only does substitute care necessitate complete reallocation of the responsibilities for care and guidance of the child, but it also means an almost total, though hopefully temporary, separation from his natural family, a change of geographical location, a change of school, and a change of peers.

The process of deciding on a particular placement for a child is involved and complicated. In order to determine some of the complications, the problems, advantages, and disadvantages of each placement alternative will be examined.

Probation

Probation is a case disposition which allows the child to remain in his own home. In social terms probation is a form of treatment which is administered by probation officers, or juvenile court counselors, on a casework basis (Reinemann, 1959, p. 610). As indicated earlier, probation for children preceded the establishment of juvenile courts by thirty years. In 1869, Massachusetts passed a law which provided for the supervision of juvenile delinquents by a state agency (Reinemann, p. 610). Other states, New York, Indiana, and Illinois, soon followed suit. Probation systems have been established in two major ways: state agencies or county departments.

The literature is replete with discussion of the use of casework 
in a juvenile court setting. Questions have been raised as to whether casework can be practiced in an "authoritarian" setting. Pray (1959, p. 815) contends that social casework can and must be practiced in the treatment of juvenile delinquents. He reminds us that:

-. the function of social casework in facilitating social adjustment is not . . to free the individual from all limitations; it is not to assist him to achieve without let or hindrance, any or all of the ends to which he might aspire, but rather it is to help him to face, to understand, to accept, and to deal constructively and responsibly with certain realities of his own situation, his own capacities and also the facts of his social setting.

Weiss (1959, p. 826) adds that there are no essential differences between a social worker's tasks and those of a probation officer. He recognizes, however, the differences in settings and in the kinds of symptoms the child in need of help brings with him.

Ideally, probation should be used only when the home situation appears to be conducive to the proper upbringing of the child and the adjustment of the child in the relative freedom of his community is feasible with the help of the supervision and authority of the court. The selection of probation must be guided by all the factors which are manifested in an individual case (Reinemann, 1959, p. 612).

The process of probation includes regular contacts between the probation officer and the child. In most situations, a child is required to meet certain conditions of probation. These include: - . obedience to parents, regular school attendance, keeping of early hours, following instructions by the probation 
officer, notification to the court of changes of address, and staying away from undesirable companions and from disreputable places (Reinemann, 1959, p. 613).

Experience has shown that the probation officer must become acquainted with all a spects of the child's life and environment, especially with the family. He continues his ongoing diagnosis of the child's adjustment and alters his treatment plan accordingly. In positive terms, probation can be considered as the most individualistic form of treatment. It applies the methods and values of social casework and authority. It further allows the child to remain in his normal home surroundings and enlists community resources on the child's behalf (Reinemann, 1959, p. 618).

Unfortunately, the reality of everyday probation practices does not often approach the ideal as outlined above. Many counties do not have probation services. Sussmann and Baum (1968, p. 80) refer to a 1947 survey which reported that out of a total of 3,071 counties in the country, 1,610 had no probation departments. They also cite a more recent study in 1966 which revealed some increase. Thirty-one states representing 74 percent of all the counties had established probation services. Reinemann (1959, p. 615) warns that probation should not be used automatically for a first offense nor should it be used with misgivings only because other alternatives are lacking. 
Foster Home Placement

The history of foster homes for children also has its roots in English history. Its beginnings can be traced to the breakdown of the feudal system with the resultant development of indenture of dependent children as apprentices, who were removed from their parents' homes to those of their masters. This system of indenture of both children and adults was imported to the United States with the early colonists.

Later, concomitantly with the beginnings of the Industrial Revolution and the growing concern about the child labor problems, the use of foster homes developed. From 1853 to 1879 , the Children's Aid Society had a massive program of sending children out of the crowded large eastern cities to the West and South. In 1866 , the Massachusetts State Board of Charities and the Boston Children's Aid Society began to pay for boarding homes, seemingly recognizing that orphanages were not the only answer to caring for dependent child ren (Williams, 1959, p. 654).

Foster homes for dependent and destitute children have been justified by the increasing acceptance of the importance of a homelike environment in the social adjustment of a child. At the same time, there has been spreading dissatisfaction with institutions for children (Williams, 1959, p. 652).

Over the years several types of foster homes have evolved, 
each with a definite purpose. Adoption homes are used to provide temporary custodial, and/or, study homes until a child is placed in a permanent home. In the past, wage and work homes have been used, usually for older children as a bridge between their natural family homes and the establishment of their own homes. The most common form has been a boarding home in that an agency or family pays for the care of the child. More recently, group homes have emerged as a possible alternative for adolescent children who need some emotional distance from adults, yet are capable of managing in the normal community (Charnley, 1955, p. 222). One way in which foster homes have been used for delinquent children has been for "after care" when they leave an institution. This type of foster home is used to test the child's ability to act more responsibly back in the community. Williams (1959, p. 655) emphasizes that foster homes should be considered as an alternative in disposition of a case only as a result of "diagnosis of the child and his situation." Kadushin (1967, p. 364) outlines the conditions which would indicate the use of foster homes. These conditions include the detrimental effects of marital discord on the child, broken homes, abuse or neglect, and emotional disturbances of the child which have been activated and are maintained while in contact with his natural parents. He has also described inappropriate uses of foster care: (1) the child presents problems of behavior that would not be tolerated in the community, (2) there is a 
handicap which requires some special care, (3) the natural parents are persistent in their objections to foster care, (4) the child is threatened by the divided loyalty to parental figures, and (5) in special situations where siblings need to be together yet cannot be placed in the same foster home.

A foster home is a home; yet, it usually remains for the child and the foster parents forever foster. Gilpin (1959, p. 662) insists that:

A foster home is not a treatment center. Foster parents are not trained in psychology or psychiatry. Nor would we want them to be. They are parents. They are people who have achieved a successful living of their own lives and who want to share their lives and a home with a child.

Kadushin (1967, p. 375) speaks further of the ideal of matching a foster home to a child, thus realizing the goal of individualization. In an attempt to accomplish this, he notes that emphasis in evaluating a possible foster home has moved from mere physical adequacy to a greater concern for the social and psychological adequacy of the home.

Even though there appears to be consensus regarding the desirability of a foster home as a placement choice, there are draw backs to this alternative. The major handicap is the lack of good foster homes, especially for delinquent children, although williams (1959, p. 655) contends that "la family home can be found for almost any child regardless of his behavior problem or offenses." He bases his views on the experiences of Boston Children's As sociation but 
does not relate its recruitment practices. The analysis of Oregon's child welfare needs and services verifies the great scarcity of foster homes for the adolescent and the youth with behavior problems (Greenleigh Associates, 1968, p. 166). In another study of 235 agencies around the country it was found that only 99 used foster homes and only 10 operated group homes (The President's Commission on Law Enforcement and Administration of Justice, 1967, p. 7).

Institutional Placement

A children's institution is a group of unrelated children living together, and basically separate from the community, in the care of unrelated adults. Institutions for children have been established for various needs and purposes. These include schools for the blind, deaf, and retarded children as well as for the emotionally disturbed, unwed mothers, and delinquent and dependent children. They are either privately or publicly financed. In an attempt to differentiate the methods of care dispensed, institutions have been grouped into two major categories: treatment-oriented or correctional.

The establishment of children's institutions, as with the other alternatives of placement, can be traced to the apprentice and indenture systems in colonial times. Special institutions for delinquents were established in the $1820^{\prime} s$. In 1825 , the first House of Refuge was founded in New York City which provided specialized treatment 
separate from adults. Even though this was a landmark development, it perpetuated the indenture system in a prison-like setting until a child's majority (Teeters, 1959, p. 673). In 1854, institutions for delinquents were established on a cottage-type style which was modeled on German experience. This physical plan has carried over into our present day institutions (Teeters, 1959, p. 674).

The faults of institutions have been exhaustively examined in the literature; nevertheless, it is recognized that institutions will always be required for certain children. Some need special treatment which can be provided only in an institution. Many need a refuge from intolerable home environments; others need to be incarcerated to protect them from damaging themselves or others. Still others need a more controlled setting where they can hopefully develop more acceptable habits and more successful interpersonal relationships (Glueck, 1959, p. 670).

Again, Kadushin (1967, p. 521) enumerates some advantages and characteristics of institutional care for children. Institutions provide a safe psychological and physical distance from parental figures. This is especially significant in working with adolescents who are experiencing the natural process of breaking away from their parents and whose behavior makes it difficult for them to be in a home setting. Institutions also give a child a greater variety of adults with whom to relate and choose as models. These include house parents, 
teachers, social workers, and even maintenance personnel. Oftentimes, in institutions children experience for the first time some structure to their lives in the form of controls such as rules, rewards, and punishment. The peer group also exercises control over the individual's behavior. Ideally, institutions can provide the opportunity to plan the child's daily living experiences for optimum the rapeutic goals with the use of specially trained personnel.

The trend has moved from merely custodial to treatmentoriented institutions. Even so, different segments of society have somewhat differing views of institutional goals. Those who work in the field of juvenile delinquency contend that a training school should provide a re-educative treatment program geared to the development of a healthy personality and a successful adjustment to society. On the other hand, the taxpayers expect the institution to control the child without a recurrence of delinquent conduct and to provide some training which will help him to become a contributing member of society. Still, the child who is sent to the institution recognizes neither the benefits of the placement nor accepts the goals set by either the staff or the community (U. S. Dept. H. E. W., Children's Bureau, 1959, p. 694-5).

These differing perceptions of what an institution should do and be have contributed to their many faults and problems. It is recognized that institutions are in urgent need of improvement. For 
example, they suffer from lack of money with a resultant lack of inadequate facilities and of trained personnel on all levels. As with foster homes and probation services, institutions are not always distributed according to need.

Summary

The preceding gives the rationale for selecting each of the alternatives in placement of a child upon his leaving a detention facility. Problems inherent in each choice have also been examined. These issues are experienced in other nations as well as our own. Hepworth (March-April, 1970) found many of the same problems in Canada. Jaffe (December, 1967) attempted to identify and describe the factors associated with differential placement of dependent children in Israel.

Although international in its scope and implications, the problem of differential placement is especially relevant and urgent in the state of Oregon. In an exhaustive study of all facets of Oregon's child welfare programs, it was determined that in 85 percent of the cases under jurisdiction of the juvenile courts, placement of the child in substitute care could have been prevented if counseling or psychiatric services had been available (Greenleigh Associates, 1968, p. 170). It was believed that the lack of treatment resources in the community resulted in inappropriate institutional commitments. It was estimated 
that one fourth to one half of the total commitments were inappropriate (Greenleigh Associates, 1968, p. 170).

As presently structured, juvenile court departments in Oregon compete with the welfare departments for the available foster homes. The welfare departments have neither the staff nor the money to provide the homes needed by the juvenile courts. In addition, the courts are not guided by statewide standards for foster homes. As a result, in some communities foster homes used by the juvenile courts are less than adequate (Greenleigh Associates, 1968, p. 170).

There are few alternatives in placing children in Oregon. More than 2,000 children were held in jails in 1963 (Greenleigh Associates, 1968, p. 165). Foster homes are often not available because of lack of funds. The better financed private institutional facilities for children frequently have no openings; thus the stateoperated training schools are the only alternative to leaving the child in his present situation. A vivid example is cited in the afore mentioned study (Greenleigh Associates, 1968, p. 109):

A 14 year old white boy was referred by the juvenile department for placement in a foster home or in a private institution because of neglect and mistreatment by his parents who could not cope with his problems. Because no placement could be arranged, he was sent to McLaren School for Boys.

It is, then, of vital importance to examine the variables which seem to have significance in differential placement of children from a juvenile court detention facility. 


\section{SELECTED VARIABLES}

$\underline{\text { Introduction }}$

The criteria for the selection of the following independent variables have already been delineated. There is no significance to the order in which these variables are discussed. The examination of each variable will first consider its relationship to the causes of delinquency and dependency. A discussion of each one's relevance to the differential placement of a child upon leaving a juvenile court detention facility will follow. Finally, the more significant variables will be noted.

$\underline{\text { Sex }}$

There seems to be a difference of opinion as to what effect the sex of a juvenile has upon his treatment or placement. Robins and Hill (September, 1966, p. 334) urge its inclusion as a factor in future research on causes and treatment of juveniles.

Kahn (1953, p. 52) found in his study of the juvenile court sys tem in New York City that delinquent boys were less likely than girls to be placed on probation or have their cases discharged. His research indicates that more boys than girls were placed in institutions; however, in dependency or neglect cases there was not as much variation in disposition between boys and girls. In Kadushin's (1967, p. 529) study of children in institutions, two out of every three 
were boys.

Yet, Terry (July, 1967) questions the validity of the assumption that boys are dealt with more severely than girls. His study on discrimination in the handling of juvenile offenders reveals the opposite trend. An earlier study by Cohn (July, 1963, p. 263) supports this. She learned that three times as many girls as boys went to institutions.

$\underline{\text { Religion }}$

Religion is included as a variable in this study to determine the validity of recording religious affiliation in social histories. It would appear to have some bearing on the placement plan for the child. The researchers' own experience is that the only time religious affiliation may have some importance is when a parent requests a foster home placement of his own religious background.

The literature indicates, however, that the mere listing of religious affiliation is not precise enough in considering its influence on a child's actions. Nye (1958) examines family relationships and delinquent behavior. He determines that church attendance has more significance in influencing non-delinquent behavior than church affiliation. Allen and Sandhee (February, 1967, p. 264) define this variable even more specifically. They conclude that the strength of religious feeling is related to degree of delinquency more than either 
religious affiliation or frequency of attendance.

To add to the confusion concerning the importance of this variable, several studies of the variables in a prehearing report find that religious data is not at all significant in the treatment plan (Gross, July, 1967; Terry, July, 1967; and Cohn, July, 1963).

Race

Race is also a controversial variable. Robins and Hill (September, 1966, p. 334) emphasize the importance of including ethnic background as a factor in studying the causes of delinquency. In their research on probation effectiveness, Scarpitti and Stephenson (March, 1968$, p. 363$)$ show that the greater proportion of the population in the state reformatory was Negro, while probationers were equally divided racially. Cohn (July, 1963, p. 264) found similar results in examining the criteria for probation officers' recommendations. She determined that fewer Negroes were recommended for discharge than for institutionalization; but, race did not seem to be a factor in recommending probation.

Terry (July, 1967), on the other hand, seems to rule out race as having any significance in the severity of a disposition, even though his study contains a preponderance of Negroes and MexicanAmericans. 
Number of Siblings

Social histories always include a statement regarding the composition of the family. It appears to be important for the counselor to know not only the number of siblings, but also the particular child's ranking among his siblings as well as the quality of his relationship to the se brothers and sisters.

Research concerning the number of siblings and their relationship to causes of dependency and delinquency is scarce. The Gluecks' (1968, p. 11) sample of delinquents came from larger families than the sample of non-delinquents. Their study concludes that, contrary to popular belief, only children, first born children, and youngest children, who are supposed to be more vulnerable to behavior difficulties are found in lower proportions in the delinquent group than in the non-delinquent group. Nye's (1958) study of family relationship and delinquency indicates a correlation with sex and size of the family. With boys there is less delinquency in small families; with girls there is no association.

The relationship of the number of siblings to differential placement is unclear. This subject does not appear to be of much interest to researchers as there was no mention of this relationship in the literature studied. Again, this variable is included in this study to test the logic of recording it in the social history. 
Marital Status of Natural Parents

Marital status of natural parents emerges as a significant factor in the review of the literature on the causes and treatment of delinquency and dependency. The marital status of a child's parents is considered to be an important predictor of these problems (Van West, June, 1964; Robins and Hill, September, 1966, p. 334). Gran (1961) interviewed judges and convicts in an effort to determine why children become delinquent. Eighty percent of the judges felt that 'mother and father divorced" was a factor, while 50 percent of the convicts agreed it was of importance (Gran, 1961, p. 193). The Gluecks' (1968) extensive research project comparing delinquents and non-delinquents confirms these opinions.

Further investigation indicates, however, that the degree of happiness of the marriage is more closely related to delinquent behavior than whether the marriage is an original one, a remarriage, or a situation in which the child is living with one parent only (Nye, 1958). Shafer and Knudten (1970, p. 193) warn that the effects of a broken home on a child a re highly individual and vary "according to the familial role of the missing person, the child's original emotional attachment to this person and the age and sex of the child."

The relationship of this variable to placement is also clearly supported in the literature, although again there is a caution to define the term, "marital status," more precisely. Nye (1958) determines 
that children of broken homes are over-represented in state institutions. The situation seems to be similar for dependent children. Jaffe's examination of the correlates of differential placement for this group of children verifies this. Children from households with step-parents, children living with father only, and children from disintegrated families are strongly associated statistically with institutional placement (Jaffe, December, 1967, p. 400).

\section{Living Arrangement of Child Prior to Detention}

The living arrangement of the child at the time he is placed in detention facilities is another variable which is repeatedly recorded in the child's record. For this study, living arrangement of the child refers to those persons with whom he has been living prior to when he is placed in detention. Again it was difficult to sift out this variable from the literature on family background, marital status, and socioeconomic strata. Van West (June, 1964, p. 19) reviews the association between cultural background and the persistent delinquent offender. He finds that these children's homes are characterized by mixed constellations with many having three generations living in the same house. Sauber (August, 1967, p. 445) investigates the preplacement situations of families of dependent children. Her results show an equal division of one parent and two parent families; 40 percent of the sample is found in each category. This study does not indicate 
which parent or constellation of parents is present. Jaffe's (December, 1967 , p. 400) study of dependent children in Israel does define family make-up more precisely and also equates certain groupings with institutional placement. Children from households with stepparents and children living alone with the father are more likely to be placed in institutions.

Once more, the inclusion of this variable is to validate the rationale for entering this information in the social history for the purpose of arriving at a treatment plan.

$\underline{\text { Recidivism }}$

A child's previous record would seem to be of major importance in differential placement. The review of literature discloses the importance of recidivism in the eyes of the counselor or probation officer. Terry (July, 1967, p. 228) states that "the prior record of delinquent behavior appears to be the most significant criterion utilized by the juvenile court in the screening of offenders." Gross (July, 1967, p. 215-6) records items rated in the order of importance in the pre-hearing report for juveniles. The probation officers ranked as most important the following: first, the child's attitude toward the offense; second, family data; and third, previous delinquency problems. The three variables which the probation officers felt the court would consider most important were present offense data, previous 
delinguency, and the child's attitude toward the offense.

The discussion of alternatives in placement indicates that in practice there is a hierarchy, or a continuum, in the placement process. This implies that a delinquent child who commits his first offense is usually released to his parents and sent home, while a child with three or four offenses is more likely to be sent to a foster home, and those who have committed perhaps six or more offenses would be sure to be sent to a state institution. Scarpitti and Stephenson (March, 1968, p. 363), in examining probation effectiveness verify this trend, finding a higher rate of recidivism in those going to reform school. Babst and Mannering (July, 1965) compare probation and imprisonment. Their results show a higher rate of recidivism for those who had been imprisoned than for those who had been placed on probation.

\section{Reason Referred}

This factor would seem to have a direct relationship to differ ential placement of children. One would assume that a child committing a serious crime would be sent to an institution. The literature, however, has paid little attention to this relationship. Studies of the decision-making process indicate the variable to be of prime importance (Wilkens and Chandler, January, 1965; Carter, July, 1967; and Gross, July, 1967). Still, they give no indication of its influence on the actual placement plan. 
There appears to be only one study which correlates offense to differential placement of juvenile delinquents. Cohn (July, 1963, p. 270) divides offenses into two major groups: crimes against life or property and crimes against parents. The latter would indicate incorrigibility, out of control of parents, or running away. She concludes that "only $1 / 8$ of all children committing delinquencies against life or property were recommended for institutionalization, one half of those committing delinquent acts against parents were so recommended." In addition, 88 percent of those children committing an offense against property were placed on probation.

Family Income

The recording of farrity income gives some indication of the socioeconomic background from which a child comes. A basic assumption is that the economic background of a child is a predictor of delinquency and dependency. Shafer and Knudten (1970, p. 220) emphatically state that "no other delinquency factor is as strongly interwoven with other causal factors as are economic conditions." In questioning judges and convicts, Gran (1961, p. 194-6) learned that 66 percent of the judges felt poverty was a cause of delinquency and 54 percent of the convicts agreed.

Other studies warn that family income or socioeconomic status may not be definitive indicators of delinquency or dependency 
(Robins and Hill, September, 1966, p. 334; Shanley, LeFever, and Rice, June, 1966). Nye (1958) earlier determined that there was no significant difference in delinquent behavior of children in different socioeconomic strata. Terry (July, 1967, p. 228) concludes that "the severity of disposition is not the function of . . socioeconomic status" of the juvenile delinquent. Elliott (September, 1967, p. 3) states that more research on middle class delinquent and dependent children is needed in order to define more precisely the relationship between this variable and these problems.

Nevertheless, there appears to be a relationship of this variable to placement outcome. Scarpitti and Stephenson (March, 1968) find that, in their sample, those children from the lower range of the socioeconomic continuum a re more likely to be committed to the state reformatory while those of higher socioeconomic status are placed on probation. Jaffe's (December, 1967, p. 400) study reveals the same trend; children from poor families are more likely to be placed in institutions than those from higher incorme families.

\section{School Status and School Attainment}

School attainment is related to the problems of truancy and dropping out of school as well as to a child's actual mental ability. The grade itself is a crude indicator of normal behavior or of some problems. The review of lite rature has little on the relationship of 
school status to delinquency or dependency. Shafer and Knudten (1970) conclude that "the problems of prolonged and full truancy are complex. Even now their causal roles in juvenile delinquency are not fully understood." Still, Gran's (1961, p. 190) research on judges' and convicts' views of causes of delinquency indicates that all judges rated "persistent truancy" as a cause and 70 percent of the convicts agreed. "Dropping out of school" was considered to be important by 73 percent of the judges and 66 percent of the convicts. "Failure in school" was significant for 77 percent of the judges and 61 percent of the convicts. In 1950, the Gluecks determined that, in their sample, 95 percent of the truants were also delinquent. Their follow-up study of 1968 (p. 21) on this same sample reveals that "the delinquents were found to be more erratic in their intellectual capacities than the more consistent and steady non-delinquents." They also measured school attainment and lea rned that delinquent children did not complete as many years as non-delinquents (Glueck, 1968, p. 31).

Even though these studies give some support to the importance of these variables as indicators of delinquency, they do not appear to be more than moderately operative in the placement process (Gross, July, 1967 ).

$\underline{\text { Age }}$

Age is a factor in determining whether or not a child is legally 
delinquent or dependent. All states have laws setting the minimum and maximum ages for a delinquent child. It would thus seem to be important in exploring the causes of a child's problems. In examining three other variables, family structure, class, and peer groups, as contributors to juvenile delinquency, Robins and Hill (September, 1966, p. 33) find that more attention should be paid to subpopulations in terms of age in combination with sex and ethnic background as predictors of delinquency. On the other hand, Cohn (July, 1963, p. 265) seems to disagree. After analyzing the criteria for the probation officers' recommendations to the juvenile court judge, she contends that age is relatively inconsequential and other factors in the child's life should be considered.

Nevertheless, there appears to be a trend in placement patterns in regard to age. Kadushin (1967, p. 524) notes that older children tend to be placed in institutions. He records that in 1960 , one half of the 306,325 children in institutions in the United States were 15 years of age or over. The value of this type of placement for adolescents has already been discussed.

\section{Days Detained}

This variable is of particular interest to the researchers. The review of literature on this specific variable seems to be barren. Lundberg (1947, p. 337-9) emphasizes the dangers of improper use 
of detention facilities, but fails to discuss the relationship of number of days in detention to placement outcome.

Interest in this variable, however, was generated from the researchers' own observations and conversations with the staff at the Multnomah County Juvenile Court and Donald E. Long Home. It seemed that the longer a child remained in detention he would more likely be sent to an institution rather than returning to his own home or to a foster home.

\section{Counselor}

The literature is replete with studies of counselor's or social worker's perceptions in the decision-making process for differential placement of children. The literature also condemns poorly trained personnel and those with little imagination. In fairness, there is equal condemnation of society's lack of interest in both the poorly trained personnel and the development of adequate resources.

As stated earlier, a primary task of the counselor is the preparation of the social history on which the treatment plan is based. Kahn (1953, p. 170) warns of inadequately prepared social histories which result in inadequate planning for many children. He implies that poorly trained workers do not use imagination in making a satisfactory treatment plan. Among the high risk variables in Jaffe's (December, 1967, p. 400) study which were strongly associated 
statistically with institutional placement were cases handled by nongraduate social workers, and lack of creative planning on the part of the family social worker.

Matek (July, 1964) and Sauber (August, 1967), in reviewing the diagnostic process for differential placement of dependent children, conclude that a particular placement plan in many cases is not necessarily a plan of choice. The question which arises is which criteria are important to the counselor?

Gross (July, 1967), in attempting to answer this question, learned that a counselor's perceptions of criteria are influenced by his particular professional orientation. Those who lean toward a psychodynamic approach place more emphasis on data dealing with personality and family relationships than on more objective data. Briar (April, 1963, p. 166) examines the clinical judgment in foster care placement and finds that "even if one knows how a worker views the case diagnostically one cannot predict his formulation of the future course of that case." He adds that the worker then must rely on his "own idiosyncratic hunches" (Briar, April, 1963, p. 169). The lack of resources for alternatives in placement and pressures upon the counselors caused by large caseloads have previously been discussed. The limitations this project has set on this variable have also been stated. The purpose in including the name of the 
counselor as a variable is to determine if there is a pattern in a particular counselor's placement decisions.

\section{Summary}

The review of literature provides some substantiation for inclusion of the selected variables. Lack of such corroboration for particular variables has also been noted. Moreover, certain variables seem to emerge with more importance than others in regard to differential placement of children from detention facilities. These are reason referred, recidivism, school attainment, marital status of natural parents, and age. A discussion of the manner in which the variables, separately and in constellation, were tested will follow. 


\section{METHODOLOGY}

\section{INTRODUCTION}

This chapter proposes to describe the information and material used in this study, their context, and how they were developed to represent the theoretical aims of the project.

The main focus is in approximating some measure of what went into the placement of certain children detained and placed during a specific time period. Using a stratified random sample for study, it is hoped that some inferences can be made about the population, such that any one instance of detention could be selected, and subsequent placement could be predicted with reasonable probability. Placement, as the dependent variable, will also provide the basis for sample stratification and is the actual sample unit in the study. As such, it would be possible for the same child to appear in the sample more than once, as he or she could have gone through the placement process several times during the delineated time span.

Three methods of approach have been selected in order to achieve proposed theoretical goals. The first involves a descriptive analysis of the random sample, in terms of the variables selected for data collection. Next, a statistical analysis of the significance of 
variables will be completed using the Chi square testing method on discrete variables, and an analysis of variance on those with interval data. Finally, several discriminant function values will be computed, in order to evaluate how specific variables, in combination, affect placement.

\section{POPULATION DESCRIPTION}

The population upon which this study is based is comprised of 2,240 juvenile admissions to the Donald E. Long Home during the Calendar Year 1969. These admissions were characterized by detention of children past a preliminary hearing, pending a decision in relation to placement alternatives. The population represents approximately one half of the total admissions to the facility during the calendar year.

Other population characteristics include a variety of referral sources, including law enforcement officers, social agencies, schools, parents, friends, and in some cases the child himself. The age range is from 18 years at the upper extreme to as low as 7 years in certain cases of dependency.

Only those children for which the Multnomah County Juvenile Court had the responsibility for determination of discharge placement, and actually made the disposition, are considered by the study. In addition, the population represents only those cases in which the 
placement was clearly identifiable from the information available through the court records.

\section{COLLECTION AND ORGANIZATION OF DATA}

A preliminary assessment of the records available at the juvenile court revealed that there was no one particular source which could provide all of the information ultimately needed concerning each placement.

The detention home receiving ledger was utilized as a source of base data to accomplish the initial task of identifying members of the population (Appendices A and B). The ledger contains all the names of children admitted to the home, date of admission, release date, and disposition, in addition to other statistical data. By comparing admission and release dates, children held beyond their preliminary hearings were identified. By referring to a 1969 calendar, time was allowed for those days when hearings were not held:

Saturdays, Sundays, and holidays. Cases in which there was some question as to whether they should be included in the population were further cross checked against a separate preliminary hearing record.

The procedure used for recording specific units of the population consisted of dividing recording sheets into 16 individual squares. When each child's name was judged as a valid sample unit, the name and placement code letters were entered in a square. A number 
corresponding to the month of the year was also recorded in order to facilitate case identification following random sampling. Once this task was accomplished, the sheets were cut into their respective divisions and grouped according to similar disposition or placement codes. Table I illustrates the range of placement dispositions within the population.

\section{STRATIFICATION OF POPULATION}

Because the concern of the study is with what types of children were being sent to the various placement possibilities, there was a desire to assure a representative number in the sample from all placement choices. Thus, a decision was made to stratify the population according to placement. Weinberg and Schumaker (1969) point out that this procedure is justified where sub-groups within the population have meaning for the data being gathered, in which case non-proportionality would make a sample non-representative and perhaps misleading. This is particularly relevant in this study because of the desirability to evaluate the characteristics of children placed in a wide range of settings. Sub-grouping was accomplished by ascertaining each placement possibility occurring in the population. As each of the possible outcomes emerged, basic similarities suggested four major categories, paralleling those identified with the description of differential placement included in Chapter II. 
TABLE I

POPULATION PLACEMENT DISTRIBUTION

\begin{tabular}{|c|c|}
\hline Detention Code & Disposition \\
\hline 1. $\mathrm{RP}$ & Return to parents \\
\hline 2. $\mathrm{YCC}$ & Youth Care Center \\
\hline 3. FHW & Foster Home Welfare \\
\hline 4. $\mathrm{YP}$ & Youth Progress \\
\hline 5. FHO & Foster Home Other \\
\hline 6. $\mathrm{YA}$ & Youth Adventures \\
\hline 7. FHC & Foster Home Court \\
\hline 8. $\mathrm{GH}$ & Group Home \\
\hline 9. Parry Center & Parry Center \\
\hline 10. $\mathrm{CH}$ & Children's Home \\
\hline 11. DSH & Dammasch State Hospital \\
\hline 12. $S M$ & St. Mary's School for Boys \\
\hline 13. $\mathrm{LH}$ & Louise Home \\
\hline 14. CS & Christie School \\
\hline 15. WSH & White Shield Home \\
\hline 16. OSH & Oregon State Hospital \\
\hline 17. EL & Edgefield Lodge \\
\hline 18. $F H$ & Fairview Home \\
\hline 19. VSR & Villa St. Rose \\
\hline 20. MSB & MacLaren School for Boys \\
\hline 21. HSG & Hillcrest School for Girls \\
\hline
\end{tabular}


The population of 2,240 admissions were placed in a total of 21 different settings. A large portion of the total were returned to their parents, forming a clear division from the rest of the population. Another clear division contains those placed via commitment in the two state correctional institutions for children. The third category includes various types of foster home placement. The last group comprises those placements in institutional settings, public and private, in which the primary emphasis is upon treatment of the individual within a therapeutic milieu. Statements of policy and treatment philosophy provided the basis for inclusion in this area. The four subdivisions were organized according to the following guidelines:

I. Placement in Parent's Home

II. Placement in Foster Home
A. Youth Care Center
B. Foster Home - Welfare
C. Youth Progress
D. Foster Home - Court
E. Foster Home - Other
F. Youth Adventures
G. Group Home

III. Placement in Non-Correctional Institutions
A. Parry Center for Children
B. Children's Farm Home
C. Dammasch State Hospital
D. St. Mary's School for Boys
E. Louise Home for Girls
F. Christie School
G. White Shield Home
H. Oregon State Hospital
I. Edgefield Lodge
J. Fairview Home
K. Villa St. Rose School for Girls 
IV. Placement in Correctional Institutions

A. MacLaren School for Boys

B. Hillcrest School for Girls

The foregoing divisions were adopted as stratification guidelines. The group placement totals are shown in Table II.

TABLE II

PLACEMENT ALTERNATIVES AND NUMBERS OF INDIVIDUAL PLACEMENTS IN EACH GROUP

\begin{tabular}{|c|c|c|c|}
\hline Group I & Group II & Group III & Group IV \\
\hline \multirow[t]{11}{*}{$\mathrm{RP}$} & YCC & Parry Center & MSB \\
\hline & FHW & $\mathrm{CH}$ & HSG \\
\hline & YP & $\mathrm{DSH}$ & \\
\hline & FHC & SM & \\
\hline & $\mathrm{FHO}$ & $\mathrm{LH}$ & \\
\hline & YA & CS & \\
\hline & $\mathrm{GH}$ & WSH & \\
\hline & & $\mathrm{OSH}$ & \\
\hline & & EL & \\
\hline & & $\mathrm{FH}$ & \\
\hline & & VSR & \\
\hline 1,612 & 210 & 104 & 214 \\
\hline
\end{tabular}


Random Sample

Using a three- and four-digit number system, each slip of paper with a child's name and placement was assigned a consecutive number. The four groups were assigned separately. The actual sample was drawn from each area with the use of a random number table.

In order to insure sufficient representation for Chi square analysis, the selection from each group was a total of five percent or a minimum of thirty placements. In the cases of the second, third and fourth groups, a random sample of five percent did not constitute the necessary minimum, and subsequently, at least thirty units were selected in each group. The total random sample was 173 :

$\begin{array}{ll}\text { Group I } & 80 \\ \text { Group II } & 31 \\ \text { Group III } & 30 \\ \text { Group IV } & 32\end{array}$

Individual Unit Data Collection

The names of individual children in the random sample of 173 were correlated manually with the case numbers assigned by the court central files. It was necessary to refer to the individual case records at this point in order to secure data recorded on the Children's Bureau's Juvenile Court Statistical Card (Appendix C). In addition, 
further information was obtained from the individual face sheets contained in each file (Appendix D).

Data collection recording was accomplished utilizing a code sheet to facilitate keypunching material for later analysis. The code sheet (Appendix E) categorized the selected variables for study, and the options within each variable were numbered correspondingly. Number codes were recorded on IBM layout sheets.

Three variables, school attainment, age, and days detained, were treated as continuous in this study. School attainment was recorded to the nearest grade actually completed. Age was recorded to the nearest tenth of a year. The actual number of days a child was held in detention was also recorded. Remaining variable data was taken from the court forms as entered. It is therefore recognized that there were some limitations imposed by the availability of information.

IBM cards were keypunched from layout sheets, one for each placement unit, utilizing a total of thirty-five columns to reflect data gathered for each admission to detention and subsequent dispositional placement.

\section{PRELIMINARY SURVEY}

In the recording process, it was noted that codes for "no information" appeared frequently enough to raise a question about the 
significance of absent information as it might relate to further analysis. A preliminary group of 25 cases was examined; however, the information yielded was not sufficient to rule out the random appearance of missing data. This suggested that a frequency tabulation would be the most efficient method to evaluate the extent and significance of the missing information prior to proceeding with any other analysis of data.

Tabulation was accomplished through utilization of an IBM card sorter. Variable code totals, in addition to pinpointing where information was missing, also suggested some basic layout revisions. Results of tabulation can be found in Table III.

TABLE III

SUMMARY OF DATA FREQUENCY TABULATION

OF INDEPENDENT VARIABLES

Independent Va riable

Frequency

SEX

Male 90

Female

RELIGION

Protestant

Catholic

Jewish

Mormon

None

No Information 
TABLE III (cont'd)

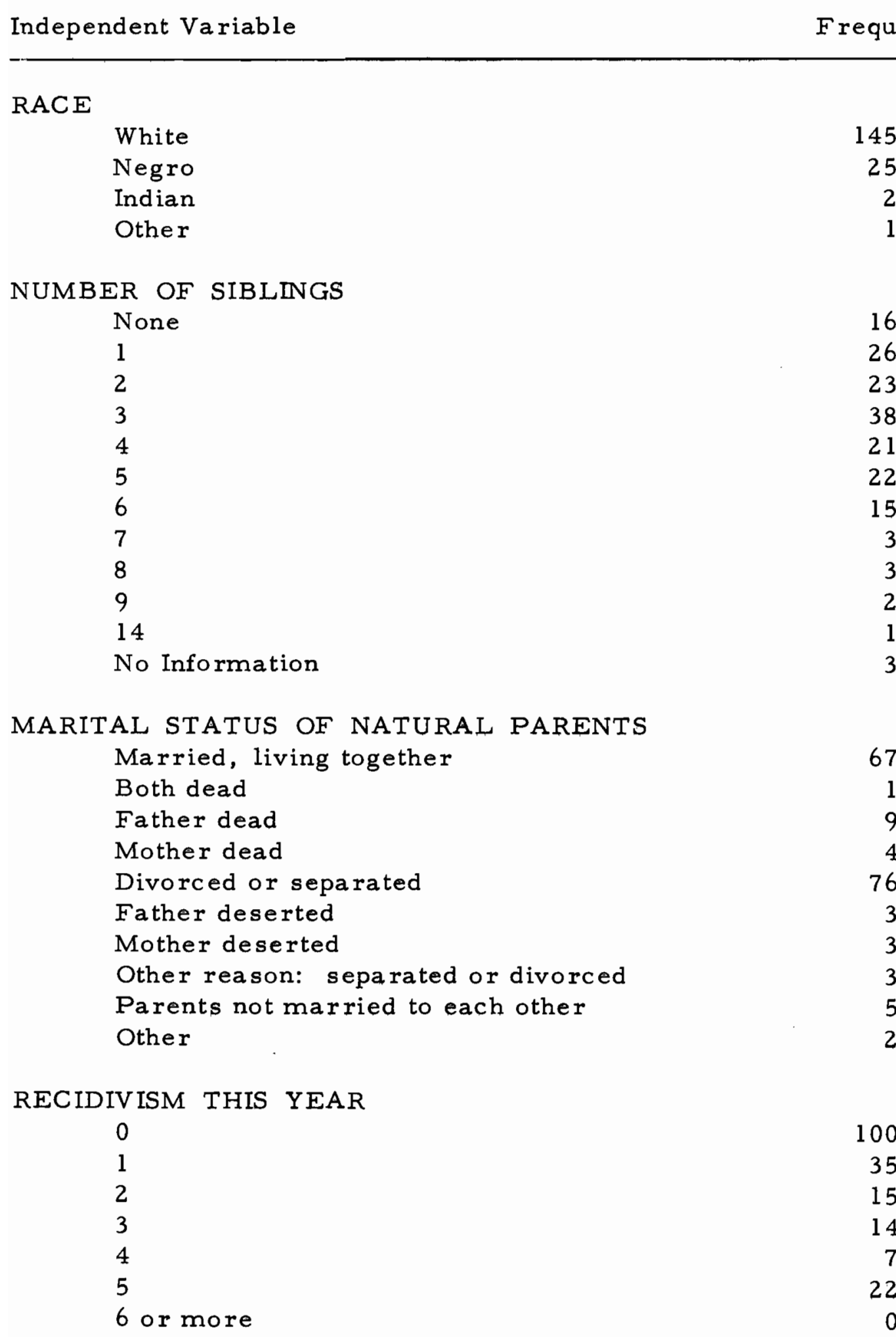


TABLE III (cont'd)

\begin{tabular}{lr} 
Tndependent Variable & Frequ \\
\hline RECIDIVISM PRIOR YEARS & \\
0 & 73 \\
1 & 28 \\
2 & 16 \\
3 & 14 \\
4 & 12 \\
5 & 16 \\
6 or more & 14 \\
& \\
LIVING ARRANGEMENT OF CHILD & 60 \\
With both parents & 9 \\
Father and stepmother & 23 \\
Mother and stepfather & 27 \\
Mother only & 4 \\
Father only & 5 \\
Relatives & 25 \\
Foster Home & 14 \\
Institution & 2 \\
Independent & 4 \\
Other &
\end{tabular}

$\begin{array}{lr}\text { REASON REFERRED } & \\ \text { Runaway-home } & 44 \\ \text { Incorrigible } & 34 \\ \text { Protective custody } & 16 \\ \text { Runaway - foster home } & 10 \\ \text { Burglary } & 9 \\ \text { Shoplifting } & 9 \\ \text { Narcotics } & 8 \\ \text { Runaway - institution } & 6 \\ \text { Minor in possession } & 3 \\ \text { Sex offense } & 3 \\ \text { Truancy } & 3 \\ \text { Curfew } & 2 \\ \text { Robbery } & 2 \\ \text { Vandalism } & 2 \\ \text { Failure to appear } & 2 \\ \text { Armed, dangerous weapon } & 1 \\ \text { Assault } & 1\end{array}$


TABLE III (cont'd)

\begin{tabular}{|c|c|}
\hline Independent Variable & Frequency \\
\hline \multicolumn{2}{|l|}{ REASON REFERRED (cont'd) } \\
\hline Drinking & 1 \\
\hline Forgery & 1 \\
\hline Larceny & 1 \\
\hline Obt. money under false pretenses & 1 \\
\hline Petty larceny & 1 \\
\hline Possession stolen property & 1 \\
\hline Prostitution & 1 \\
\hline Disorderly conduct & 1 \\
\hline \multicolumn{2}{|l|}{ FAMILY INCOME } \\
\hline Public Assistance & 22 \\
\hline Under $\$ 3,000$ & 2 \\
\hline$\$ 3,000-\$ 4,999$ & 11 \\
\hline$\$ 5,000-\$ 9,999$ & 53 \\
\hline$\$ 10,000$ up & 17 \\
\hline Unknown & 68 \\
\hline \multicolumn{2}{|l|}{ SCHOOL STATUS } \\
\hline In school & 132 \\
\hline Not in school & 41 \\
\hline \multicolumn{2}{|l|}{ SCHOOL ATTAINMENT } \\
\hline 0 & 1 \\
\hline 1 & 0 \\
\hline 2 & 1 \\
\hline 3 & 1 \\
\hline 4 & 5 \\
\hline 5 & 4 \\
\hline 6 & 8 \\
\hline 7 & 17 \\
\hline 8 & 50 \\
\hline 9 & 32 \\
\hline 10 & 36 \\
\hline 11 & 15 \\
\hline 12 & 1 \\
\hline No information & 2 \\
\hline
\end{tabular}


The most significant discovery in terms of missing data was that 39 percent of the sample did not have the income of the family recorded. Data was missing in approximately the same proportion from each group. There was no other feasible source from which to obtain this information; therefore any inferences about the population with regard to family income will be speculative. The data available was carried through for any observation of trends which might be present, suggesting further study.

The variable, counselor, although admittedly one that could be significant in terms of the placement process, does not lend itself well to examination in this study. The results of coding the individual counselor's name as sociated with each sample unit yielded the information that there were more than forty counselors concerned with the sample of 173 placement units, and none of the se forty appeared 10 percent or more in any particular group. It was, therefore, decided to eliminate this variable from further study.

Other data on the cards was missing in quantities of 20 percent or less, and was considered adequate for further analysis.

With regard to preparation for Chi square tests for independence, it could be seen that some variables with widespread diversity would need to be sub-grouped in a logical way for sufficient numbers in each cell of the testing procedure.

The following changes and re-groupings were made: 
1. STATUS UF NATURAL PARENTS

Group 1 - Married, living together

Group 2 - One or both dead

Group 3 - Divorced or legally separated

Group 4 - Desertion by one or the other parent, parents not married to each other, other reasons.

2. LIVING ARRANGEMENTS OF CHILD

Group 1 - With both parents

Group 2 - With one or the other parent and step-parent

Group 3 - With mother or father only

Group 4 - With relatives, in foster homes, institutions, independent, other

3. RECIDIVISM

Group 1 - 0

Group $2-1$

Group $3-2$

Group $4-3$ or more

4. REASONS REFERRED

Of the variety of referral codes taken from the detention home ledger, only 26 were found to appear in the sample. These fell into three major categories:

Group 1 - Juvenile crimes

Group 2 - Adult crimes

Group 3 - Dependency cases

Following recoding and re-grouping, IBM cards were $r=-$

punched, reflecting the changes in layout plan (Appendix F). In addition, it was necessary to refine specific variables again, subsequent to the second keypunching process, as data was not yet in appropriate groupings for Chi square testing. The additional changes were:

5. RELIGION

Group 1 - Catholic

Group 2 - Protestant, Mormon

Group 3 - None 
6. RACE

Group 1 - White

Group 2 - Negro

Eliminated Indian, other ( 3 cases)

7. SIBLINGS

$$
\begin{aligned}
& \text { Group } 1-0-2 \\
& \text { Group } 2-3-4 \\
& \text { Group } 3-5+
\end{aligned}
$$

After this final regrouping was accomplished, the data was in the order necessary for analysis by the three previously outlined statistical approaches. A discussion of the analysis and interpretation of the findings will follow. 


\section{CHAPTER IV}

\section{DATA ANALYSIS AND INTERPRETATION OF FINDINGS}

\section{INT RODUCTION}

Evaluation of collected data was accomplished at three levels. First, sample variables were described by means of frequency and percentage distribution. Units representing actual occurrence within variables were expressed as percentages. It is the intent of this segment of the study to discuss frequency distributions and percentage compositions only with respect to their within group representation. Other tables representing range and median of tabulated data are included on certain variables.

In addition, eleven discrete variables were subjected to $\mathrm{Chi}$ square analysis to test if frequency of data was compatible with theoretical expected ratios determined by chance alone. A 5 percent level of significance was accepted for tests conducted. In the case of three continuous variables offering interval data, analyses of variance were completed to examine whether the separate means of several groups differ significantly from each other.

Finally, a more comprehensive analysis was accomplished by means of discriminant function testing on four groups of variables to ascertain how accurately given placement units would be distributed 
over the four placement groupings. The basis for grouping is as follows: (1) five variables supported by the review of literature as most important, (2) a constellation of variables including those demonstrated to be statistically significant as a result of Chi square tests, and (3) two additional combinations of variables of special interest to the researchers.

As set forth in the research design, it was necessary to subgroup many of the variables to insure cells of sufficient numerical magnitude for Chi square analysis. The tables presented in this segment of the study represent the groupings utilized in testing the data. A more definitive compendium containing actual numbers and percentages prior to sub-grouping is furnished in the Appendix.

\section{DESCRIPTIVE DATA}

$\underline{\text { Sex }}$

An examination of the four placement groups discloses that the percentage of males in each group slightly exceeds that of females, with the exception of Group III. In that category the percentage of females to males is more than two to one which may be the result of the greater availability of treatment institutions for girls.

As a result of Chi square testing, the variable sex was not found to significantly influence placement within the sample, thereby 
TABLE IV

FREQUENCY AND PERCENTAGE DISTRIBUTION

OF SEX BY PLACEMENT

\begin{tabular}{|c|c|c|c|c|c|c|c|c|}
\hline \multirow[b]{3}{*}{ Sex } & \multicolumn{8}{|c|}{ Placement Group } \\
\hline & & I & & II & & III & & IV \\
\hline & \multicolumn{2}{|c|}{ No.. Percent } & \multicolumn{2}{|c|}{ No. Percent } & \multicolumn{2}{|c|}{ No. Percent } & \multicolumn{2}{|c|}{ No. Percent } \\
\hline Male & 48 & $(60)$ & 16 & $(52)$ & 10 & $(31)$ & 16 & $(53)$ \\
\hline Female & 32 & $(40)$ & 15 & $(48)$ & 22 & (69) & 14 & $(47)$ \\
\hline Totals & 80 & $(100)$ & 31 & $(100)$ & 32 & $(100)$ & 30 & $(100)$ \\
\hline
\end{tabular}

not rejecting the null-hypothesis of independency between variable and placement.

\section{$\underline{\text { Religion }}$}

It was observed that numerically, Protestant children dominated all four placement groups; however, this preponderance is much less evident in Group IV where the number indicating "no religious preference" constitutes 40 percent of the sample. While Protestant children compose 53 percent of this placement category, it is their smallest representation among the four groups. Catholic representation is highest in Group I, making up 18 percent of the total within 
TABLE V

FREQUENCY AND PERCENTAGE DISTRIBUTION
OF RELIGION BY PLACEMENT

\begin{tabular}{|c|c|c|c|c|c|c|c|c|}
\hline \multirow[b]{3}{*}{ Religion } & \multicolumn{8}{|c|}{ Placement Group } \\
\hline & & $\mathrm{I}$ & & II & & III & & IV \\
\hline & No. & Percent & No. & Percent & No. & Percent & No. & Percent \\
\hline Catholic & 14 & (18) & 2 & (6) & 3 & (9) & 2 & (7) \\
\hline $\begin{array}{l}\text { Protestant } \\
\text { and Mormon }\end{array}$ & 52 & $(65)$ & 20 & $(65)$ & 24 & $(75)$ & 16 & (53) \\
\hline $\begin{array}{l}\text { No preference } \\
\text { indicated }\end{array}$ & 14 & $(18)$ & 9 & $(29)$ & 5 & $(16)$ & 12 & $(40)$ \\
\hline Totals & 80 & $(100)$ & 31 & $(100)$ & 32 & $(100)$ & 30 & $(100)$ \\
\hline
\end{tabular}

Group I with 9 percent being the highest distribution in the remaining three groups.

The null hypothesis that placement of the child is independent of religious preference was rejected. The statistically significant Chi square of the sample suggests that there is a dependent relationship between religious preference of the child and the placement. This is particularly evident in the relatively large number of Catholic children being released to their parents (Group I) and the high percentage of children with no religious preference who are sent to correctional institutions (Group IV). 
Although it is difficult to speculate why the representation of Catholic children is highest in Group I, it was observed during data collection that there was a relatively high incidence of runaway referrals among the Catholic youth incarcerated in the sample. Further, the data revealed that a large percentage of runaways was released to parents. This would seem to offer an explanation for Group I having the highest Catholic representation. In addition, the profession of Catholic affiliation often connotes strong familial ties and perhaps at times exercises some influence on the placement decision. The implicit importance of religious affiliation might also be evidenced within the fourth group which has the highest percentage of children indicating no religious preference.

$\underline{\text { Race }}$

Although the design of this study did provide for four racial possibilities, the sample did not contain sufficient representation in the Indian and Other categories for use in Chi square analysis. Due to the small numbers in this category, the data anlysis was limited to a study of white and Negro children. An examination of the frequency distribution within the four placement categories reveals that the proportion of white to Negro children in each group remains relatively constant with the third and fourth groups representing the extremes.

The Chi square value of the sample was insufficient to 
TABLE VI

FREQUENCY AND PERCENTAGE DISTRIBUTION

OF RACE BY PLACEMENT

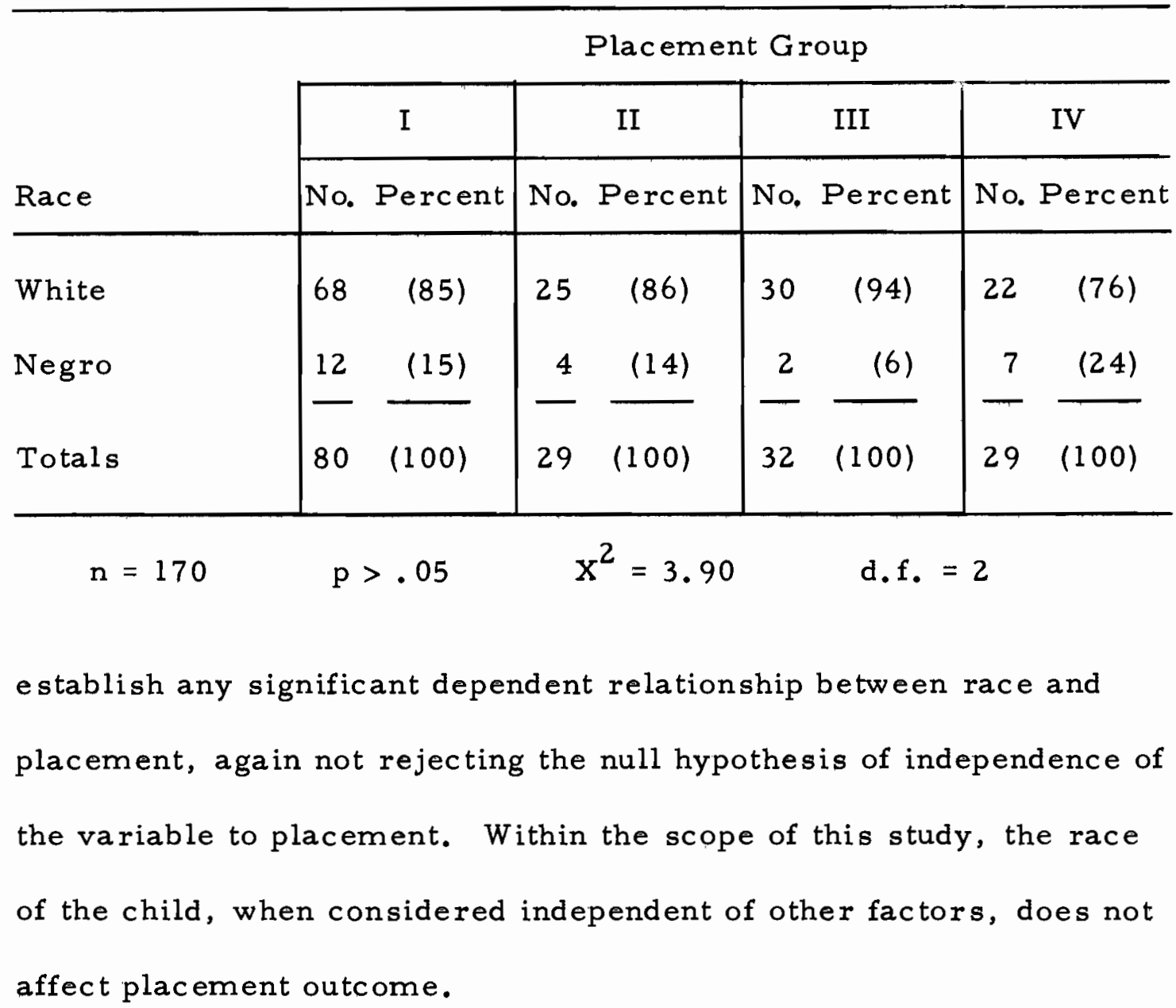

Number of Siblings

The distribution of the number of siblings among the four placement groups does not yield any clear or definitive patterns. Children placed in treatment institutions (Group III) a re somewhat more likely to come from large families than those in the other groups. It was observed that children released to their parents 
(Group I) represented the lowest percentage of children with five or more siblings.

TABLE VII

FREQUENCY AND PERCENTAGE DISTRIBUTION OF NUMBER OF SIBLINGS BY PLACEMENT

\begin{tabular}{|c|c|c|c|c|c|c|c|c|}
\hline \multirow{3}{*}{$\begin{array}{l}\text { Number of } \\
\text { Siblings }\end{array}$} & \multicolumn{8}{|c|}{ Placement Group } \\
\hline & & $\mathrm{I}$ & & II & & III & & IV \\
\hline & No. & Percent & No. & Percent & No. & Percent & No. & Percent \\
\hline $0-2$ & 36 & $(45)$ & 12 & $(39)$ & 8 & $(25)$ & 9 & $(30)$ \\
\hline $3-4$ & 29 & $(36)$ & 9 & $(29)$ & 10 & $(31)$ & 11 & $(37)$ \\
\hline 5 plus & 15 & $(19)$ & 10 & $(32)$ & 14 & $(44)$ & 10 & (33) \\
\hline Totals & 80 & $(100)$ & 31 & $(100)$ & 32 & $(100)$ & 30 & $(100)$ \\
\hline
\end{tabular}

Chi square was computed for the sample in order to examine the null hypothesis that placement of a juvenile is independent of the number of siblings. The value obtained from this analysis did not indicate a dependent relationship. Therefore, the null hypothesis was not rejected. Test results suggest that the number of brothers and sisters a child has does not influence placement outcome when viewed apart from other controlling factors. 
Marital Status of Natural Parents

Examination of the frequency distribution for the variable, marital status of natural parents, discloses a marked similarity between the percentage composition of Group I and Group III, but

TABLE VIII

FREQUENCY AND PERCENTAGE DISTRIBUTION OF MARITAL STATUS OF NATURAL PARENTS BY PLACEMENT

\begin{tabular}{|c|c|c|c|c|c|c|c|c|}
\hline \multirow[b]{3}{*}{ Marital status } & \multicolumn{8}{|c|}{ Placement Group } \\
\hline & & I & & II & & III & & IV \\
\hline & No. & Percent & No. & Percent & No. & Percent & No. & Percent \\
\hline $\begin{array}{l}\text { Married } \\
\text { together }\end{array}$ & 37 & $(46)$ & 9 & (29) & 13 & $(41)$ & 8 & $(27)$ \\
\hline $\begin{array}{l}\text { One or both } \\
\text { deceased }\end{array}$ & 7 & (9) & 2 & $(6)$ & 3 & $(9)$ & 2 & (6) \\
\hline $\begin{array}{l}\text { Divorced or } \\
\text { legally } \\
\text { separated }\end{array}$ & 31 & (39) & 14 & $(45)$ & 14 & $(44)$ & 17 & $(57)$ \\
\hline $\begin{array}{l}\text { Unmarried or } \\
\text { otherwise } \\
\text { separated }\end{array}$ & $\begin{array}{r}5 \\
-\end{array}$ & (6) & $\begin{array}{r}6 \\
-\end{array}$ & $\begin{array}{r}(20) \\
\end{array}$ & $\begin{array}{r}2 \\
-\end{array}$ & (6) & $\begin{array}{r}3 \\
-\end{array}$ & $(10)$ \\
\hline Totals & 80 & $(100)$ & 31 & $(100)$ & 32 & $(100)$ & 30 & $(100)$ \\
\hline
\end{tabular}

offers somewhat diffuse data when comparing Group II with Group IV. The first group contains the highest percentage of children with 
parents married and living together and the lowest percentage with parents that are divorced or legally separated. The converse was found to be true in the fourth group. Placement Groups II and IV resemble each other with respect to the characteristics referred to in Group I but differ in the fourth category of marital status of natural parents. The value yielded from Chi square testing was not sufficient to establish a dependent relationship between marital status of natural parents and placement, therefore not rejecting the null hypothesis of independence between variables. Marital status of natural parents does not significantly affect the placement decision when other variables are not controlled.

\section{Living Arrangement of Child Prior to Detention}

Of the four possibilities for living arrangement of the child, percentages vary widely between Group I and the remaining three groups. Seventy percent of the children who were released to their parents were living in two parent families, with both natural parcits or one natural parent and one step-parent, prior to detention. This is in contrast to Groups I, .III, and IV, in which children living in two parent families prior to detention comprised only 35 percent, 44 percent, and 37 percent, respectively. An obvious disparity between placement groups was recognized in the fourth living arrangement category which includes foster home, institution, independent living or other. In Group I, only 6 percent of the children were from this 
living arrangement, whereas Group II contained 47 percent, Group III contained 53 percent and Group IV contained 45 percent. Children coming from one parent families represent a much smaller percentage of Group III than they did in the other groups.

TABLE IX

FREQUENCY AND PERCENTAGE DISTRIBUTION OF LIVING ARRANGEMENT OF CHILD PRIOR TO DETENTION BY PLACEMENT

\begin{tabular}{|c|c|c|c|c|c|c|c|c|}
\hline \multirow{3}{*}{$\begin{array}{l}\text { Living } \\
\text { Arrangement }\end{array}$} & \multicolumn{8}{|c|}{ Placement Group } \\
\hline & & $I$ & & II & & III & & IV \\
\hline & No. & Percent & No. & Percent & No: & Percent & No. & Percent \\
\hline Both parents & 38 & $(46)$ & 7 & (23) & 10 & $(31)$ & 6 & $(20)$ \\
\hline $\begin{array}{l}\text { Parent and } \\
\text { step-parent }\end{array}$ & 19 & $(24)$ & 4 & $(13)$ & 4 & (13) & 5 & $(17)$ \\
\hline $\begin{array}{l}\text { One parent } \\
\text { only }\end{array}$ & 19 & $(24)$ & 5 & $(16)$ & 1 & (3) & 6 & $(20)$ \\
\hline $\begin{array}{l}\text { Foster home, } \\
\text { institution, } \\
\text { independent } \\
\text { living, other }\end{array}$ & 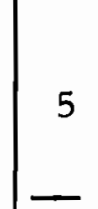 & $(6)$ & $\begin{array}{r}15 \\
-\end{array}$ & $(48)$ & $\begin{array}{r}17 \\
- \\
\end{array}$ & (53) & $\begin{array}{r}13 \\
- \\
\end{array}$ & $(43)$ \\
\hline Totals & 80 & $(100)$ & 31 & $(100)$ & 32 & $(100)$ & 30 & $(100)$ \\
\hline
\end{tabular}

The computed Chi square value significantly related the placement of the child to his living arrangement prior to detention. Test 
results clearly indicated a dependent relationship between this variable and placement. Therefore, the null hypothesis of independence of variable to placement was rejected. Findings indicate that the re is a trend to return children to living situations similar to those from which they came. If a child entered detention from a living arrangement other than with parents or step-parents, it is statistically improbable that he will be placed in Group I. Such a phenomenon further accentuates the finality of the legal separation of the child from his parents. Contrary to professional values, it would appear from this study that within the context of the juvenile court system, little effort is expended toward achieving the goal of maintaining the child with his parents. Once a child is removed from his home, emphasis is placed on his behavior and psychosocial adjustment independent from his parents. As a result, the goal shifts from improving family functioning to facilitating a child's adjustment in a substitute living situation.

The findings of this study indicate that a high percentage of children are placed in treatment and correctional institutions only after experiencing a substitute family living situation. It is conceivable that this stems from an attitude on the part of the counselors that, in most cases, foster care should be attempted before considering institutional placement.

It must be noted that those children in Group IV do not include 
anyone previously committed to a correctional institution. Reference to prior institutional living arrangements is confined to those institutions defined as treatment oriented.

\section{$\underline{\text { Recidivism }}$}

This year: In examining the number of times each child in the sample was referred to the court during the study year 1969 , it was observed that a wide deviation among groups occurs in the case of multiple referrals. Any inference that can be drawn regarding placement of children with two or fewer referrals during the year is basically inconclusive.

TABLE $X$

FREQUENCY AND PERCENTAGE DISTRIBUTION OF RECIDIVISM THIS YEAR BY PLACEMENT

\begin{tabular}{|c|c|c|c|c|c|c|c|c|}
\hline \multirow{3}{*}{$\begin{array}{l}\text { Recidivism } \\
\text { this year }\end{array}$} & \multicolumn{8}{|c|}{ Placement Group } \\
\hline & & I & & II & & III & & IV \\
\hline & No. & Percent & No. & Percent & No. & Percent & No. & Percent \\
\hline None & 49 & $(61)$ & 19 & $(61)$ & 19 & $(59)$ & 13 & (43) \\
\hline One & 12 & $(15)$ & 6 & (19) & 11 & $(35)$ & 6 & $(20)$ \\
\hline Two & 10 & (13) & 2 & (7) & 1 & (3) & 2 & (7) \\
\hline Three and over & 9 & $(11)$ & 4 & (13) & 1 & (3) & 9 & $(30)$ \\
\hline Totals & 80 & $(100)$ & 31 & $(100)$ & 32 & $(100)$ & 30 & $(100)$ \\
\hline
\end{tabular}


The Chi square value computed for this variable was statistically significant, causing the null hypothesis of independence between recidivism this year and placement to be rejected. The implication of multiple referrals for placement is illustrated by the fourth group (correctional institutions) which has the highest percentage of children with three or more referrals during the year 1969. It would appear that within the study sample a child referred for numerous offenses is more likely to be placed in a correctional institution than the other placement possibilities.

Prior years: Observations made about recidivism in prior years closely parallel those made with regard to recidivism during the study year 1969.

The Chi square test for this variable also significantly related recidivism to placement, leading to a rejection of the null hypothesis that placement is independent of recidivism in previous years. It is quite apparent from the test results that children within the study sample with three or more referrals are statistically more likely to be placed in correctional institutions.

It is obvious from the information obtained with respect to recidivism that the number of offenses a child commits weighs heavily on the placement decision. This would seem to contradict the agency philosophy of placing a child in that living situation most consistent 
TABLE XI

FREQUENCY AND PERCENTAGE DISTRIBUTION OF RECIDIVISM IN PRIOR YEARS BY PLACEMENT

\begin{tabular}{|c|c|c|c|c|c|c|c|c|}
\hline \multirow{3}{*}{$\begin{array}{l}\text { Recidivism in } \\
\text { prior years }\end{array}$} & \multicolumn{8}{|c|}{ Placement Group } \\
\hline & & $\mathrm{I}$ & & II & & III & & IV \\
\hline & No. & Percent & No. & Percent & No. & Percent & No. & Percent \\
\hline None & 40 & $(50)$ & 14 & $(45)$ & 12 & (37) & 7 & (23) \\
\hline One & 13 & $(16)$ & 7 & $(23)$ & 6 & (19) & 2 & (7) \\
\hline Two & 5 & $(6)$ & 2 & $(6)$ & 6 & (19) & 3 & $(10)$ \\
\hline Three and over & 22 & $(28)$ & 8 & $(26)$ & 8 & $(25)$ & 15 & $(60)$ \\
\hline Totals & 80 & $(100)$ & 31 & $(100)$ & 32 & $(100)$ & 30 & $(100)$ \\
\hline
\end{tabular}

with his individual needs. Rather, the evidence seems to reflect that the agency acts in response to the demands placed upon it by the greater society to punish the "bad" child.

\section{Reason Referred}

Among the reasons for a child being referred to the court, the commission of a juvenile offense is the most frequent in each group. In Groups I and IV, referrals for adult offenses constitute a relatively large percentage of the total referrals within the respective group sample. Referrals for adult offenses and for dependency are 
equally represented in Group II and Group III.

TABLE XII

FREQUENCY AND PERCENTAGE DISTRIBUTION

OF REASON REFERRED BY PLACEMENT

\begin{tabular}{|c|c|c|c|c|c|c|c|c|}
\hline \multirow{3}{*}{$\begin{array}{l}\text { Reason } \\
\text { referred }\end{array}$} & \multicolumn{8}{|c|}{ Placement Group } \\
\hline & & I & & II & & III & & IV \\
\hline & No. & Percent & No. & Percent & No. & Percent & No. & Percent \\
\hline $\begin{array}{l}\text { Juvenile } \\
\text { offense }\end{array}$ & 47 & (59) & 19 & $(62)$ & 22 & (69) & 16 & (53) \\
\hline Adult offense & 30 & (37) & 6 & (19) & 5 & (16) & 12 & $(40)$ \\
\hline Dependency & 3 & (4) & 6 & (19) & 5 & $(16)$ & 2 & (7) \\
\hline Totals & 80 & $(100)$ & 31 & $(100)$ & 32 & $(100)$ & 30 & $(100)$ \\
\hline
\end{tabular}

Computed Chi square for the groups was of sufficient magnitude to reflect a dependent relationship between placement and season for referral. The null hypothesis of independency between variable and placement was the refore rejected.

It is quite apparent that a very high percentage of the total dependency referrals in the study sample was placed in either foster homes or treatment institutions. Such referrals a re invariably the result of a breakdown in family functioning. Legal and ethical 
standards dictate that children in this category should not be placed in correctional facilities.

Family Income

It must be noted that this portion of the study is limited in the observations made $w$ ith regard to this variable due to the relatively high number of cases in which information concerning family income was not available. The data reflected in the frequency distribution presented represents only 61 percent of the total sample.

A review of the available data yields a wide variety of responses with the only consistency appearing in the $\$ 5,000$ to $\$ 9,999$ category which represents the highest percentage of occurrence in each placement group. Although there are no families falling in the $\$ 10,000$ and over category in Group III, very little emphasis should be placed on this observation since information concerning income is lacking in more than 50 percent of the families within this group. Chi square analysis of available data for the sample does not disclose a statistically significant dependent relationship between placement and family income. This finding implies that placement is not influenced by family income. 
TABLE XIII

FREQUENCY AND PERCENTAGE DISTRIBUTION

OF FAMILY INCOME BY PLACEMENT

\begin{tabular}{|c|c|c|c|c|c|c|c|c|}
\hline \multirow[b]{3}{*}{ Income } & \multicolumn{8}{|c|}{ Placement Group } \\
\hline & & I & & II & & III & & IV \\
\hline & No. & Percent & No. & Percent & No. & Percent & No. & Percent \\
\hline $\begin{array}{l}\text { Public } \\
\text { assistance }\end{array}$ & 9 & (16) & 7 & $(35)$ & 4 & $(27)$ & 3 & $(18)$ \\
\hline Under $\$ 3,000$ & 1 & $(2)$ & 0 & $(0)$ & 0 & $(0)$ & 1 & $(6)$ \\
\hline$\$ 3,000-\$ 4,999$ & 5 & (9) & 3 & $(15)$ & 3 & $(20)$ & 0 & $(0)$ \\
\hline$\$ 5,000-\$ 9,999$ & 27 & $(50)$ & 8 & $(40)$ & 8 & $(53)$ & 10 & $(58)$ \\
\hline $\begin{array}{l}\$ 10,000 \\
\text { and ove r }\end{array}$ & 12 & $(23)$ & 2 & $(10)$ & 0 & $(0)$ & 3 & $(18)$ \\
\hline Totals & 54 & $(100)$ & 20 & $(100)$ & 15 & $(100)$ & 17 & $(100)$ \\
\hline
\end{tabular}

\section{$\underline{\text { School Status }}$}

Great similarity was observed in the percentage composition of Groups I and IV. Groups II and III also resemble each other in composition, but differ markedly from the other two groups. The most remarkable configuration occurs in the second group in which only one child, or 3 percent, was not attending school at the time of referral.

A test for independency between placement and this variable was accomplished utilizing Chi square analysis. Testing was conducted 
TABLE XIV

\section{FREQUENCY AND PERCENTAGE DISTRIBUTION \\ OF SCHOOL STATUS BY PLACEMENT}

\begin{tabular}{|c|c|c|c|c|c|c|c|c|}
\hline \multirow[b]{3}{*}{ School status } & \multicolumn{8}{|c|}{ Placement Group } \\
\hline & & $\mathrm{I}$ & & II & & III & & IV \\
\hline & No. & Percent & No. & Percent & No. & Percent & No. & Percent \\
\hline In school & 55 & $(69)$ & 30 & (97) & 27 & $(84)$ & 20 & (67) \\
\hline Out of school & 25 & $(31)$ & 1 & (3) & 5 & $(16)$ & 10 & (33) \\
\hline Totals & 80 & $(100)$ & 31 & $(100)$ & 32 & $(100)$ & 30 & $(100)$ \\
\hline
\end{tabular}

without controlling for other variables. A dependent relationship between placement and school status was supported by a statistically significant Chi square value, therefore leading to rejection of the null hypothesis. From the sample data, it is clear that children placed in foster homes and treatment institutions are more likely to have been in school at the time of referral than those released to their parents or placed in correctional institutions.

This may be partially a result of the younger children that comprise Groups II and III. Experience indicates that the possibility for school drop-out increases with older children. In addition, foster homes and treatment facilities are generally oriented toward accepting children who are attending school. Consequently, there is likely to be a reluctance on the part of court counselors to consider chronically truant children for such placements. 
School Attainment

Collected data is seen to include those with no education through those who have completed the twelfth grade. Although the four group means do not differ greatly, the within group variability appears to be much different. Group III contains those children who have completed fewer grades, as might be expected due to the institutional treatment nature of the placement choices. Emotional and psychological impairment is more frequent in this group.

An analysis of variance was completed, and findings indicate that the variance between group means relative to the va riability within group is greater than that which would be expected by chance alone, given that all four groups had the same mean. It is therefore concluded that there is a dependent relationship between placement and school attainment.

The influence of school attainment on placement must be viewed with respect to the age of the child in question. From a crossgroup perspective, the school attainment was approximately two years behind the expected level of achievement for that age. The preponderance of children studied are clustered in the eighth, ninth, and tenth grade levels, with an over all mean age of 15.22 years for the four placement groups. It can be observed that Group III has the lowest mean grade completed (7.28); however, as previously demonstrated, children in this group are likely to be younger. 
TABLE XV

FREQUENCY AND PERCENTAGE DISTRIBUTION OF SCHOOL AT TAINMENT BY PLACEMENT

\begin{tabular}{|c|c|c|c|c|c|c|c|c|}
\hline \multirow{3}{*}{$\begin{array}{l}\text { School } \\
\text { attainment }\end{array}$} & \multicolumn{8}{|c|}{ Placement Group } \\
\hline & \multicolumn{2}{|r|}{ I } & \multicolumn{2}{|r|}{ II } & \multicolumn{2}{|r|}{ III } & \multicolumn{2}{|r|}{ IV } \\
\hline & No. & Percent & No. & Percent & No. & Percent & No. & Percent \\
\hline None & & & & & 1 & (3) & & \\
\hline Second & & & 1 & (3) & & & & \\
\hline Third & & & 1 & (3) & & & & \\
\hline Fourth & 1 & $(1)$ & 1 & (3) & 3 & (9) & & \\
\hline Fifth & 1 & (1) & & & 3 & (9) & & \\
\hline Sixth & 3 & (4) & 2 & (6) & 3 & (9) & & \\
\hline Seventh & 3 & $(4)$ & 4 & (13) & 5 & $(16)$ & 5 & $(17)$ \\
\hline Eighth & 25 & $(31)$ & 7 & (23) & 9 & $(28)$ & 9 & $(30)$ \\
\hline Ninth & 13 & $(16)$ & 7 & $(23)$ & 1 & $(3)$ & 11 & $(37)$ \\
\hline Tenth & 23 & (29) & 4 & $(13)$ & 4 & $(13)$ & 5 & $(16)$ \\
\hline Eleventh & 10 & (13) & 4 & $(13)$ & 1 & $(3)$ & & \\
\hline Twelfth & 1 & (1) & & & & & & \\
\hline No information & & & & & 2 & (7) & & \\
\hline Totals & 80 & $(100)$ & 31 & $(100)$ & 32 & $(100)$ & 30 & $(100)$ \\
\hline Means & & 8.96 & & 8.12 & & 7.28 & & 8.53 \\
\hline
\end{tabular}


TABLE XVI

ANALYSIS OF VARIANCE: SCHOOL ATTAINMENT

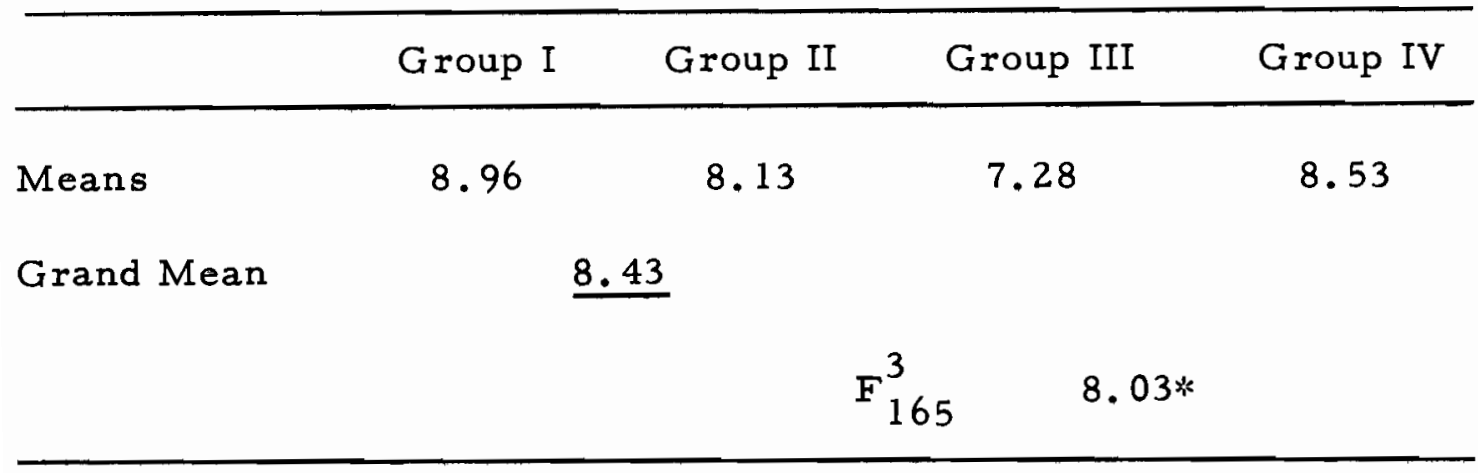

* F Table was used to determine statistical significance with $\mathrm{p} \leq .05$.

Age

The sample contains age representation from 8.1 years to 18. 3 years, distributed unequally over the four placement groups.

TABLE XVII

RANGE OF AGE REPRESENTATION BY GROUP

\begin{tabular}{ccccc}
\hline & \multicolumn{4}{c}{ Placement Group } \\
\cline { 2 - 5 } & I & II & III & IV \\
\hline Age Range & $11.8-18.3$ & $8.1-16.9$ & $8.6-15.5$ & $12.2-17.1$ \\
\hline
\end{tabular}

The appearance of younger children in Group II and Group III might be explained by the fact that the percentage of dependency cases referred for protective custody is highest in these groups. Also, this can be partially accounted for by the propensity of treatment 
institutions (Group III) to accept referrals on younger children. Of the available treatment institutions, only Louise Home and Villa Saint Rose routinely accept referrals on children age fourteen and beyond. Furthermore, it is generally recognized that it is easier to place younger children in foster care (Group II) than those in their middle and late teens. Contrary to the review of literature which supports the assumption that older children are sent to correctional institutions, the trend observed from the collected data indicates that as a child approaches age eighteen he is more likely to be released to parents than placed elsewhere. The posture of the juvenile court in cases dealing with children of this age group seems to be to dispose of the referral with a reprimand. Serious offenses are customarily remanded to adult court for adjudication and disposition.

An analysis of variance was completed with the findings suggesting that the variance between the group means in relation to the variability within each group is greater than expected by chance. This suggests that the age of a child has a statistically significant influence on the placement outcome.

The null hypothesis that the placement of a child is independent of age was rejected. The analysis of variance suggests that there is a dependent relationship between the age of the child and placement. 
TABLE XVIII

ANALYSIS OF VARIANCE: AGE

\begin{tabular}{|c|c|c|c|c|}
\hline & Group I & Group II & Group III & Group IV \\
\hline Means & 15.88 & 14.77 & 14.05 & 15.41 \\
\hline \multirow[t]{2}{*}{ Grand Mean } & \multicolumn{2}{|c|}{15.28} & & \\
\hline & & & $F_{165}^{3}$ & \\
\hline
\end{tabular}

* F Table was used to determine statistical significance with $\mathrm{p} \leq .05$

School Attainment, Age, and Days Detained: Pooled Information

By pooling information collected on the three variables, school attainment, age and days detained, a correlation matrix was completed.

TABLE XIX

CORRELATION MATRIX: SCHOOL ATTAINMENT, AGE, AND DAYS DETAINED

\begin{tabular}{lccc}
\hline & Age & Days Detained & $\begin{array}{c}\text { School } \\
\text { Attainment }\end{array}$ \\
\hline Age & 1 & -.13 & .81 \\
Days Detained & & -.13 \\
School Attainment & & \\
\hline
\end{tabular}

Findings would indicate that there is a high level of positive relationship between the age of a child and his attainment in school. 
In other words, the older the child, the higher level of grade attained.

In some respects, this might not be surprising. However, in view of the fact that many of the children in the sample are frequently in and out of school, sometimes dropping out completely, the correlation might be expected to be lower.

The matrix indicates further that neither the age of a child nor his school attainment correlated with the number of days he is held in detention prior to dispositional placement.

\section{Days Detained}

Data tabulation of the sample shows the overall number of days detained for any one child to range from 2 to as long as 119 days. The range and median in each placement group are shown.

TABLE XX

RANGE AND MEDLAN OF DAYS DETAINED BY GROUP

\begin{tabular}{lcccc}
\hline & \multicolumn{4}{c}{ Placement Group } \\
\cline { 2 - 5 } $\begin{array}{l}\text { Days } \\
\text { Detained }\end{array}$ & I & II & III & IV \\
\hline Range & $2-92$ & $3-119$ & $2-92$ & $2-37$ \\
Median & 7 & 19 & 39 & 16 \\
\hline
\end{tabular}

The above information suggests that children in Groups II and III stay in detention longer than those in Groups I and IV. This might 
be accounted for by the fact that foster homes and treatment institutions are few in number and openings are not as readily available as in the other two groups. In addition, preparation of referral material for these placements is tedious and time consuming and some delay can be anticipated while the prospective agency is processing the intake. Often, the final placement decision must be postponed pending results of the referral to the desired agency.

An analysis of variance was completed, suggesting that the number of days a child is detained is significantly related to his eventual placement outcome, as the variance between group means relative to variability within group is greater than would be expected by chance alone.

The null hypothesis that placement is independent of days detained was rejected. The following test shows a statistically significant relationship.

TABLE XXI

ANALYSIS OF VARIANCE: DAYS DETAINED

\begin{tabular}{lcccc}
\hline & Group I & Group II & Group III & Group IV \\
\hline Means & 12.35 & 26.32 & 40.16 & 18.27 \\
Grand Mean & $\underline{21.02}$ & & & \\
& & & $F_{165}^{3}$ & $16.37 *$ \\
\hline
\end{tabular}

* F Table was used to determine statistical significance with $\mathrm{p} \leq .05$. 


\section{DISCRIMINANT FUNCTION ANALYSIS}

As a result of Chi square analysis, it was possible to determine the relationship between a variable and placement when not controlling for other factors. To broaden the scope of this study, testing by means of discriminant function was undertaken to evaluate the significance of the relationship between selected groups of variables and placement.

The purpose for utilizing this statistical procedure was to determine if placement can be predicted for an unknown child characterized by a particular combination of variables. Individual group means, common means, and discriminant function co-efficients and constants for each combination of variables studied are included in Appendix $\mathrm{H}$.

Initially, the variables, reason referred, recidivism, school status, marital status of natural parents, and age were suggested by the review of literature as more important than the others studied. They were therefore selected for the first combination to be subjected to discriminant function analysis.

Application of discriminant function testing to the above combination of variables did not produce an extremely accurate predictor of placement. While the profile provided from these five variables did result in predicting the correct disposition for 53 percent of 
TABLE XXII

DISCRIMINANT FUNCTION ANALYSIS OF FIVE VARLABLES:

REASON REFERRED, RECIDIVISM PRIOR YEARS,

SCHOOL STATUS, MARITAL STATUS OF

NATURAL PARENTS, AGE

\begin{tabular}{|c|c|c|c|c|c|}
\hline $\begin{array}{l}\text { Placement } \\
\text { Group }\end{array}$ & I & II & III & IV & Total \\
\hline I & $31(39 \%)$ & 16 & 14 & 18 & 79 \\
\hline II & 6 & $11(37 \%)$ & 5 & 8 & 30 \\
\hline III & 5 & 6 & $14(47 \%)$ & 5 & 30 \\
\hline IV & 3 & 6 & 5 & $16(53 \%)$ & 30 \\
\hline Total & 45 & 39 & 38 & 47 & 169 \\
\hline
\end{tabular}

those placed in Group IV (Table XXII), only 75 out of 169 observations were accurately placed. Forty-four percent of the total sample was found to be placed correctly within the four groups as a result of this combination, Placement by chance alone could be expected to yield 25 percent accuracy.

Religion, living arrangement of child prior to detention,

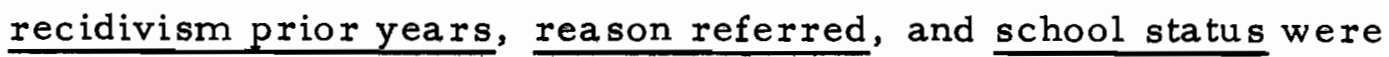
found to have statistically significant influence on placement as a result of $\mathrm{Chi}$ square analysis. In combination with age and marital

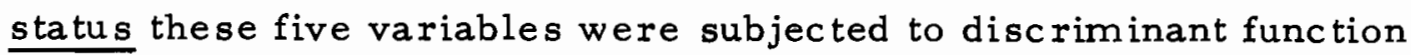
testing in order to examine their collective impact on placement. 
TABLE XXIII

DISCRIMINANT FUNCTION ANALYSIS OF SEVEN VARIABLES:

RELIGION, LIVING ARRANGEMENT OF CHILD PRIOR TO

DETENTION, RECIDIVISM PRIOR YEARS, REASON

REFERRED, SCHOOL STATUS, AGE, MARITAL

STATUS OF NATURAL PARENTS

\begin{tabular}{l|c|c|c|c|c|}
\hline $\begin{array}{l}\text { Placement } \\
\text { Group }\end{array}$ & I & II & III & IV & Total \\
\hline \multirow{3}{*}{ I } & $44(56 \%)$ & 10 & 8 & 17 & 79 \\
\cline { 2 - 7 } III & 9 & $10(33 \%)$ & 9 & 2 & 30 \\
\cline { 2 - 7 } IV & 6 & 4 & $18(60 \%)$ & 2 & 30 \\
\cline { 2 - 7 } Total & 66 & 7 & 2 & $14(47 \%)$ & 30 \\
\hline
\end{tabular}

As a placement profile, this group of seven variables viewed in combination provided 50 percent overall accuracy within the four groups in predicting where a child would be placed.

Finally, this study examined two additional combinations of variables of special interest to the researchers, generated from their own personal experiences and observations. Tables XXIV and XXV reflect the results of discriminant function analysis of the se groupings.

The degree of accuracy reflected in this pair of tables clearly resembles that yielded in the preceding analyses.

As a result of the discriminant function tests conducted, it 
TABLE XXIV

DISCRIMINANT FUNCTION ANALYSIS OF FIVE VARLABLES: AGE, NUMBER OF SIBLINGS, SCHOOL ATTAINMENT, FAMILY INCOME, DAYS DETAINED

\begin{tabular}{l|c|c|c|c|c|}
\hline $\begin{array}{c}\text { Placement } \\
\text { Group }\end{array}$ & I & II & III & IV & Total \\
\hline \multirow{2}{*}{ I } & $47(59 \%)$ & 10 & 5 & 17 & 79 \\
\cline { 2 - 6 } II & 7 & $7(23 \%)$ & 10 & 6 & 30 \\
\cline { 2 - 6 } III & 5 & 6 & $16(53 \%)$ & 3 & 30 \\
IV & 10 & 7 & 2 & $11(37 \%)$ & 30 \\
\hline Total & 69 & 30 & 33 & 37 & 169 \\
\hline
\end{tabular}

TABLE XXV

DISCRIMINANT FUNCTION ANALYSIS OF EIGHT VARIABLES: AGE, SEX, RACE, NUMBER OF SIBLINGS, SCHOOL ATTAINMENT, FAMILY INCOME, DAYS DETAINED, SCHOOL STATUS

\begin{tabular}{l|c|c|c|c|c|}
\hline $\begin{array}{l}\text { Placement } \\
\text { Group }\end{array}$ & I & II & III & IV & Total \\
\hline I & $46(57 \%)$ & 12 & 3 & 19 & 80 \\
II & 10 & $9(29 \%)$ & 9 & 3 & 31 \\
\cline { 2 - 7 } III & 6 & 4 & $21(66 \%)$ & 1 & 32 \\
IV & 7 & 3 & 1 & $14(56 \%)$ & 25 \\
\hline Total & 69 & 28 & 34 & 37 & 168 \\
\hline
\end{tabular}


was tentatively concluded that the variables encompassed by this study, when viewed in combination, were significant in predicting placement in approximately 50 percent of the placement units examined. Further, it was quite evident that for the remaining cases for which it was impossible to predict outcome, other factors not included within the scope of the study had a significant influence on placement. The relatively high degree of inaccuracy would preclude reliance on combinations of the variables studied as dependable predictors of placement. 


\section{CHAPTER V}

\section{CONCLUSIONS AND IMPLICATIONS FOR FURTHER STUDY}

\section{INTRODUCTION}

This study has been concerned with the identification, organization, and testing the significance to placement of demographic data recorded on children held past a preliminary hearing in the detention facility of the Multnomah County Juvenile Court in the year 1969. The researchers have presented findings obtained from a study of 173 children's placements, in which certain variables, selected from the demographic data, were examined as to their effect on placement outcome in four groups.

Several questions were originally posed. First, do any of the selected variables recorded in a child's court file influence his placement from the detention facility? Second, are there any specific constellations of factors that can be identified which affect his placement? Finally, on the basis of any positive findings, alone or in constellation, is it possible to predict a child's placement?

\section{CONCLUSIONS}

The evaluation of the results of this study discloses that nine of the fourteen variables considered were found to have a statistically 
significant influence on placement outcome, independent of other factors. These variables were age, religion, living arrangement of the child prior to detention, recidivism this year, recidivism prior years, school attainment, days detained, reason referred and school status.

On the basis of Chi square testing, living arrangement of the child prior to detention and recidivism show the highest level of association with differential placement. Correspondingly, the number of days a child was detained was identified as having the highest level of significance of those factors subjected to analysis of variance. When the four constellations of factors chosen for consideration in this study were subjected to examination by discriminant function analysis, no one constellation could be found to predict actual placement with more than 53 percent accuracy. Although this figure is approximately twice that expected by random placement within the four groups, the nearly equal possibility for error would seem to preclude the value of relying upon combinations of variables to predict placement. Thus, the data as produced within the scope of this research project does not provide an effective placement profile.

It is, therefore, tentatively concluded that placement outcome, while influenced in part by demographic factors, is ultimately the result of a process combining subjective as well as objective components, many of which have not been directly addressed by this study. 
While the variables examined herein do not comprise the whole of the placement process, certain salient features have emerged from the data collected. Analysis of these features advances several conclusions.

Although there is a tendency to return a child to the living arrangement from which he came, it is important to note that once he is removed from his own home, he is rarely returned to it. Moreover, the observed trend implies a progression of placement from substitute family living to treatment or correctional facilities. Perhaps this could be attributed to some effort on the part of the counselor to individualize the needs of the child.

Additionally, the fact that children who are sent to foster homes and treatment facilities remain longer in detention than those who are referred home or committed to correctional institutions may also reflect further evidence of an attempt to particularize the child's placement. However, this fact could also imply the lack of sufficient and appropriate resources for differential placement. This assumption is further substantiated by the parallel in the overall placement patterns for children who return home and those who go to correctional institutions.

The apparent lack of sufficient alternatives in placement reduces the possibility of the placement process being a treatment decision, where the individual child's needs are considered in relation to 
the stated objectives of each placement choice. Instead, differential placement seems to be by default. More succinctly, a child appears to be placed where there is an available opening.

The pivotal determinant of placement seems to be recidivism. Regardless of a child's individual characteristics, it is almost inevitable that commission of multiple offenses will ultimately result in placement in a correctional institution. Conceding a probable lack of treatment resources for delinquent children, it, nevertheless, appears likely that the sole basis for many commitments is the number of referrals to the juvenile court. This trend intimates apparent incompatibility with the professed treatment and rehabilitation philosophy of the court.

\section{MMPLICATIONS FOR FURTHER STUDY}

The implications of this study seem to be clear in regard to further research. Of greatest importance is the necessity for valid research on all aspects of the placement process. If some of the components of this process are unknown or misunderstood, even an ideal number of dispositional alternatives would not guarantee individualized treatment for each child. A more systematic knowledge of counselor judgments, perceptions of agency function, and community expectations would complement the efforts of this study to clarify the placement process. 
Assuming that implementation of the philosophy of "individualized justice" for the child would be facilitated by a wider range of treatment resources, additional research is needed to determine the appropriate extent and focus of such resources. The significance of this study is not that the findings, conclusions, and implications for further research furnish much that is new in the field of child welfare services, but that the data produced herein constitutes yet another plea for implementation of the recommendations for action. 


\section{A LIST OF WORKS CONSULTED}

\section{ARTICLES}

Allen, Donald E., and Sandhee, Harjit S. "A Comparative Study of Delinquents and Non-delinquents, Family Affect, Religion, and Personal Income." Social Forces, 46 (2, 1967), 263-9.

Babst, Dean V., and Mannering, John W. "Probation Versus Imprisonment for Similar Types of Offenders--A Comparison by Subsequent Violation." Journal of Research in Crime and Delinquency, 2 (July, 1965), 60-72.

Bender, Lauretta. "A Psychiatrist Looks at Deviancy as a Factor in Juvenile Delinquency." Federal Probation, XXXII (June, 1968), 35-42.

Blackburn, Donald G. "Institutions for Juvenile Delinquents." The Problem of Delinguency. Edited by Sheldon Glueck. Boston: Houghton, Mifflin Co., 1959.

Briar, Scott. "Clinical Judgment in Foster Care Placement." Child Welfare, XLII (Apri1, 1963), 161-9.

Carr, Lowell J. "Most Courts Have to Be Substandard." Federal Probation, XIII (September, 1949), 29-34.

Carter, Robert M. "The Presentence Report and the DecisionMaking Process." Journal of Research in Crime and Delinquency, 4 (July, 1967), 203 $=11$.

Cohn, Yona. "Criteria for the Probation Officers' Recommendations to the Juvenile Court Judge." Crime and Delinquency, 9 (July, 1963), 262-75.

Coyne, Thomas A. "Who Will Speak for the Child?" The Annals of the American Academy of Political and Social Sciences. 383 (May, 1969), 34-47.

Dunham, H. Warren. "The Juvenile Court: Contradictory Orientations in Processing Offenders." Juvenile Delinquency. Edited by Rose Giallombardo. New York: John Wiley and Sons, Inc., 1966. 
Elliott, Mabel A. "Trends in Theories Regarding Juvenile Delinquency and Their Implications for Treatment Programs." Federal Probation, XXXI (September, 1967), 3-111.

Fanshe1, David. "Commentary on 'Clinical Judgment in Foster Care Placement."' Child Welfare, XLII (April, 1963), 169-72.

Finkelstein, Harry. "The Use of Court Commitment in the Residential Treatment of Disturbed Children." Social Casework, XLV (December, 1964), 603-10.

Foster, Henry H., Jr. "The Future of Family Law." The Annals of the American Academy of Political and Social Science, 383 (May, 1969), 129-44.

Foy, Edward. "The Decision-Making Problem in Foster Care." Child Welfare, XLVI (September, 1967), 498-503.

Gardner, George E. "Ambivalence As a Factor in Home Placement Failure." The Problem of Delinquency. Edited by Sheldon Glueck. Boston: Houghton-Mifflin Co., 1959.

Gilpin, Ruth. "Foster Home Care for Delinquent Children." The Problem of Delinquency. Edited by Sheldon Glueck. Boston: Houghton-Mifflin Co., 1959.

Gross, Seymoure. "The Prehearing Juvenile Report: Probation Officers' Conceptions." Journal of Research in Crime and Delinquency, $4(\mathrm{July}, 196 \overline{7}), 203-11$.

Harmon, Maurice A. "Unraveling Administrative Organization of State Juvenile Services." Crime and Delinquency, 13 (July, 1967), 432-8.

Hepworth, H. Philip. "Children in Trouble." Canadian Welfare, 46 (March-April, 1970), 12-13.

Hirschi, Travis, and Selvin, Hanaul. "False Criteria of Causacity in Delinquency Research." Social Problems, 13 (Winter, 1966), 254-68.

Jaffe, Eliezer D. "Corrolates of Differential Placement Outcome for Dependent Children in Israel." Social Service Review, XLI (December, 1967), 390-400. 
Kahn, Alfred J. "The Social Scene and the Planning of Services for Children." Social Work, 7 (July, 1962), 3-14.

Kline, Draza. "Differential Diagnosis in Planning Placement for Children." Selected Papers in Casework, National Conference of Social Work, 1952, 129-44.

Krasnow, Erwin G. "Social Investigation Reports in the Juvenile Court--Their Uses and Abuses." Crime and Delinguency, 12 (April, 1966), $151-65$.

Maas, Henry S. "Children in Long-Term Foster Care." Child Welfare, XLVIII (June, 1969), 333-47.

Martin, J. M. "Introducing a Community Dimension into Juvenile Correction Policy-Making." Child Welfare, XLVII (May, 1968), 260-5.

Matek, O. "Differential Diagnosis for Differential Placement of Children." Child Welfare, XLIII (July, 1964), 340-8.

Meeker, Ben. "Analysis of a Presentence Report." Federal Probation, XIV (March, 1950), 41-6.

Moss, S. Z. "Integration of the Family into the Child Placement Process." Children, 15 (June, 1968), 219-24.

Passingham, R. E. "A Study of Delinquents with Children's Home Background." British Journal of Criminology, 8 (January, 1968), $32-45$.

Pleune, F. Gordon. "Effects of State Training School Programs on Juvenile Delinquents." The Problem of Delinquency. Edited by Sheldon Glueck. Boston: Houghton-Mifflin Co., 1959.

Pound, Roscoe. "The Juvenile Court in the Service State." Current Approaches to Delinquency. 1949 Yearbook of the National Probation and Parole Association. New York: National Probation and Parole Association, 1949.

Pray, Kenneth L. "The Place of Social Casework in the Treatment of Delinquency." The Problem of Delinquency. Edited by Sheldon Glueck. Boston: Houghton-Mifflin Co., 1959. 
Reeves, Elmer W. "Administrative Procedures and Casework Services." The Problem of Delinquency. Edited by Sheldon Glueck. Boston: Houghton-Mifflin Co., 1959.

Reinemann, John Otto. "Probation and the Juvenile Delinquent." The Problem of Delinquency. Edited by Sheldon Glueck. Boston: Houghton-Mifflin Co., 1959.

Rinck, Jane E. "Supervising the Juvenile Delinquent." The Problem of Delinguency. Edited by Sheldon Glueck. Boston: Houghton$\bar{M}$ ifflin Co., 1959.

Robins, Lee N., and Hill, Shirley Y. "Assessing the Contributions of Family Structure, Class and Peer Groups to Juvenile Delinquency." Journal of Criminal Law, Criminology, and Police Science, 57 (September, 1966), 325-34.

Sauber, Mignon. "Preplacement Situations of Families: Data for Planning Services." Child Welfare, XLVI (August, 1967), $443-9$.

Scarpitti, Frank R., and Stephenson, Richard M. "A Study of Probation Effectiveness." Journal of Criminal Law, Criminology, and Police Science, 59 (March, 1968), 361-9.

Shanley, Fred J.; LeFever, D. Welty; and Rice, Roger E. "The Aggressive Middle-Class Delinquent." Journal of Criminal Law, Criminology, and Police Science, 57 (June, 1966), $145-52$.

Snyder, P. R., and Mangano, A. F. "Effect of Law Guardian Representation on the Treatment of Delinquent Children." Social Work, 13 (March, 1968), 102-8.

Taber, Robert C. "The Value of Casework to the Probationer." The Problem of Delinquency. Edited by Sheldon Glueck. Boston: Houghton-Mifflin Co., 1959.

Teeters, Negley K. "Institutional Treatment of Juvenile Delinquents." The Problem of Delinquency. Edited by Sheldon Glueck. Boston: Houghton-Mifflin Co. , 1959.

Tenney, Charles W., Jr. "The Utopian World of Juvenile Courts." The Annals of the American Academy of Political and Social Sciences, 383 (May, 1969), 101-18. 
Terry, Robert M. "Discrimination in the Handling of Juvenile Offenders by Social-Control Agencies." Journal of Research in Crime and Delinquency, 4 (July, 1967), 218-30.

Tyrell, Donald J. "Why Can't We Understand Juvenile Delinquency?" Eederal Probation, XXVIII (June, 1964), 20-5.

U. S. Department of Health, Education, and Welfare, Children's Bureau. "The Role and Contribution of the Training School." The Problem of Delinquency. Edited by Sheldon Glueck. Boston: Houghton-Mifflin Co., 1959.

Van West, Alexander. "Cultural Background and Treatment of the Persistent Offender." Federal Probation, XXVIII (June, 1964), 17-9.

Walins, M. "Group Care: Friend or Foe?" Social Work, 14 (January, 1969), 35-53.

Weinstein, Noah, and Goodman, Corrine R. "The Supreme Court and the Juvenile Court." Crime and Delinquency, 13 (October, 1969), $481-7$.

Weiss, Hans. "The Social Worker's Technique and Probation." The Problem of Delinquency. Edited by Sheldon Glueck, Boston: Houghton-Mifflin Co., 1959.

Wilkins, Leslie T., and Chandler, Ann. "Confidence and Competence in Decision Making." British Journal of Criminology, 5 (January, 1965), 22-35.

Williams, Herbert D. "Foster Homes for Juvenile Delinguents." The Problem of Delinquency. Edited by Sheldon Glueck. Boston: Houghton-Mifflin Co., 1959.

Witherspoon, Arthur W. "Foster Home Placements for Juvenile Delinquents." Federal Probation, XXX (December, 1966) $118-53$.

\section{BOOKS}

Amos, Jimmy R.; Brown, Foster Lloyd; and Mink, Oscar G. Statistical Concepts. New York: Harper \& Row, Publishers, 1965. 
Beyer, Wm. H., ed. Handbook of Tables For Probability and Statistics. Cleveland: The Chemical Rubber Co., $\overline{1966 .}$

Charnley, Jean. The Art of Child Placement. Minneapolis: University of Minnesota, 1955 .

Cloward, Richard A., and Ohlin, Lloyd E. Delinquency and Opportunity. Glencoe, Ill.: Free Press, 1960 .

Eldefonso, Edward. Law Enforcement and the Youthful Offender: Juvenile Procedures. New York: John Wiley and Sons, Inc., 1967.

Glueck, Sheldon, ed. The Problem of Delinquency, Boston: Houghton-Mifflin Co., 1959.

, and Glueck, Eleanor. Delinguents and Nondelinguents in Perspective. Cambridge, Mass.: Harvard University Press, 1968.

, and Glueck, Eleanor. Unraveling Juvenile Delinguency.

Cambridge, Mass.: Harvard University Press, 1950.

Gran, John M. Why Children Become Delinquent. Baltimore:

Helican Press, 1961.

Juvenile Court Counselor's Manual. Portland, Oregon: Multnomah County Juvenile Court, (no date).

Kadushin, Alfred. Child Welfare Services. New York: The Macmillan Company, 1967.

Kahn, Alfred J. A Court for Children. New York: Columbia University Press, 1953 .

Lou, H. H. Juvenile Courts in the United States. Chapel Hill, N, C.: University of North Carolina Press, 1927.

Lundberg, Emma D. Unto the Least of These. New York: AppletonCentury-Crofts, Inc., 1947 .

Maas, Henry S. and Engler, Richard E., Jr. Children in Need of Parents. New York: Columbia University Press, 1959 . 
National Council on Crime and Delinquency. Court Services for Families and Children in Oregon. Portland, Ore.: Oregon Council on Crime and Delinquency, 1965. - Guides for Juvenile Court Judges. New York: National Council on C rime and Delinquency, 1963.

Norman, Sherwood, and Norman, Helen. Detention for the Juvenile Court. New York: National Probation Association, 1946.

Nye, F. Ivan. Family Relationships and Delinquent Behavior. New York: John Wiley and Sons, 1958 .

Shafer, Stephen, and Knudten, Richard D. Juvenile Delinquency An Introduction. New York: Random House, 1970.

Sussmann, Frederick B., and Baum, Frederic S. Law of Juvenile Delinguency. Dobbs Ferry, N. Y.: Oceana Publications, 1968.

Tappan, Paul W. Juvenile Delinguency. McGraw-Hill Book Company, Inc., 1949.

Weinberg, George H., and Schumaker, John A. Statistics: An Intuitive Approach. Belmont, Calif.: Brooks/Cole Publishing Co., 1969 .

\section{REPORTS AND PUBLIC DOCUMENTS}

Greenleigh Associates. Child Welfare Needs and Services' Report to the Governor's Child Welfare Committee. New York: Greenleigh As sociates, Inc., 1968.

In Re Gault, 387 U. S. 1 (1967).

In Re Kent, 383 U. S. 541 (1960).

Oregon Revised Statutes, Juvenile Court Proceedings: Court Juvenile Departments, Chapter 419, 476, 1959-1963.

The President's Commission on Law Enforcement and Administration of Justice. Task Force Report: Juvenile Delinquency and Youth Crime. Washington: U. S. Government Printing Office, 1967 . 


\section{APPENDICES}




\section{APPENDIX A}

\section{INFORMATION ENTERED ON THE RECEIVING LEDGER OF THE DONALD E. LONG HOME}

Year, Month

Number

Name, last and first

Unit

Age

Religion

Race

Entry date and time

Reason for referral

Referred by

Counselor

Released, date and time

Disposition

Classification: Delinquent, Dependent, Custodial

Days brought forward

Totals

Current Month Child Care Days 
APPENDIX B

CODE FOR JUVENILE DETENTION HOME LEDGER RECORD

\begin{tabular}{cl}
\hline Item & Code \\
\hline RE-CURRENT & RC \\
New & A \\
Current Year & B \\
Not Current Year & C
\end{tabular}

$\underline{\text { RACE }}$

Indian

I

Negro

$\mathrm{N}$

Oriental

$\mathrm{O}$

White

$\mathrm{W}$

RELIGION

Catholic

Jewish

Protestant

C

Mormon

$P$

None

$\mathrm{M}$

$\mathrm{N}$

REASONS FOR REFERRAL

I. Delinquency

A rmed Robbery

AR

Arson

ARS

Armed w/Dangerous Weapon

ADW

Assault

AS

Auto Theft

AT

Burglary

Car Prow 1

BG

CP

Concealed Weapon

$\mathrm{CW}$

Curfew

CF

Drinking

DR

Forgery

FG

Incorrigibility

INC

Larceny

LC 
(cont'd)

\begin{tabular}{ll}
\hline Item & Code \\
\hline Material Witness & MW \\
Murder-Manslaughter & $\mathrm{M}$ \\
Narcotics, Use of & $\mathrm{N}$ \\
Obtaining Money Under False Pretenses & OMFP \\
Petty Larceny & PL \\
Possession of Alcohol & PA \\
Possession Stolen Property & PSP \\
Possession of Tobacco & PT \\
Prostitution & PR \\
Robbery & RB \\
Runaway - Foster Home & RFH \\
Runaway - Home & RH \\
Runaway (name institution) & RI \\
Sex Offense & SO \\
Shoplifting & SL \\
Traffic & TRA \\
Truancy & TR \\
Vandalism & VA \\
Violation of Probation & VP \\
Violation of Inst. Parole & VIP
\end{tabular}

II. Dependency

$\begin{array}{ll}\text { Abandonment } & \text { AB } \\ \text { Cruelty } & \text { C } \\ \text { Molestation } & \text { MO } \\ \text { Neglect } & \text { NEG } \\ \text { Protective Custody } & \text { PC } \\ \text { Without Parental Care or Guardianship } & \text { WPC }\end{array}$

III. Custodial

Check mark

("F" if Federal)

DISPOSITION

Albertina Kerr Homes

AKH

Boys \& Girls Aid Society

BGAS 
(cont'd)

\begin{tabular}{|c|c|}
\hline Item & Code \\
\hline \multicolumn{2}{|l|}{ Foster Homes } \\
\hline Court & FHC \\
\hline Catholic Services & FHCS \\
\hline Welfare & FHW \\
\hline Other & FHO \\
\hline Catholic Services - Supervision & CsS \\
\hline Children's Farm Home & CFH \\
\hline Children's Home & $\mathrm{CH}$ \\
\hline Christie Home & $\mathrm{CS}$ \\
\hline Dammasch State Hospital & DSF \\
\hline Decline Jurisdiction & $\mathrm{DJ}$ \\
\hline Dismissal & DIS \\
\hline Edgefield Lodge & EL \\
\hline Fairview Home & FH \\
\hline Family Counseling & FC \\
\hline Group Home & $\mathrm{GH}$ \\
\hline Hillcrest School for Girls & HSG \\
\hline Jewish Family Service & JFS \\
\hline Louise Home & LH \\
\hline Mc Laren School for Boys & MSB \\
\hline Milita ry Service (Branch) & MS \\
\hline Oregon State Hospital & OSH \\
\hline Parole Revocation & PR \\
\hline Parry Center for Children & Parry Center \\
\hline Permanent Commitment & $\mathrm{PC}$ \\
\hline Probation & $\mathrm{PB}$ \\
\hline Providence Nursery & PN \\
\hline Release to Others & RO \\
\hline Release to Parents & $\mathrm{RP}$ \\
\hline Release to Relatives & RR \\
\hline Remand - City & $\mathrm{RC}$ \\
\hline Remand - Multnomah County & RMC \\
\hline St. Mary's School for Boys & SM \\
\hline Villa St. Rose & VSR \\
\hline Volunteers of America & $\mathrm{VA}$ \\
\hline Wa rning & WAR \\
\hline Waverly Baby Home & WBH \\
\hline Welfare - for Supervision & WS \\
\hline White Shield Home & WSH \\
\hline Youth Progress & YP \\
\hline
\end{tabular}




\section{APPENDIX C}

\section{INFORMATION ENTERED ON THE CHILDREN'S BUREAU'S} JUVENILE COURT STATISTICAL CARD
A. Court
B. Child's Name or Number
C. Address
D. Date of Birth
E. Age at Time of Referral

H. Date of Referral

I. Referred By

1 Law enforcement agency

2 School department

3 Social agency

4 Probation officer

5 Parents or relatives

6 Other court

7 Other source (specify)

J. Prior Delinguency (excluding traffic) Referrals

a. This calendar year -

$$
\begin{array}{llllll}
0 & 1 & 2 & 3 & 4 & 5
\end{array} \text { or more referrals }
$$

b. In prior years -

$$
\begin{array}{llllll}
0 & 1 & 2 & 3 & 4 & 5
\end{array} \text { or more referrals }
$$

K. Care Pending Disposition

Detention or shelter care overnight or longer in:

01 Jail or police station

02 Detention home

04 Foster family home

08 Other place (specify)

L. Reason Referred

Offenses applicable to both juveniles and adults (excluding traffic)

01 Murder and non-negligent manslaughter

02. Manslaughter by negligence

03 Forcible rape

04 Robbery: Purse snatching by force

05 Robbery: All except purse snatching

06 Assault: Aggravated

07 Assault: All except aggravated

08 Burglary--breaking or entering 
09 Auto theft: Unauthorized use

10 Auto theft: All except unauthorized use

11 La rceny: Shoplifting

12 Larceny: All except shoplifting

13 Weapons-carrying, possessing, etc.

14 Sex offenses (except forcible rape)

15 Violation of drug laws: Narcotic

16 Violation of drug laws: All except narcotic

17 Drunkenness

18 Disorderly conduct

19 Vandalism

20 Other (specify)

Offenses applicable to juveniles only (excluding traffic)

31 Running away

32 Truancy

33 Violation of curfew

34 Ungovernable behavior

35 Possessing or drinking of liquor

36 Other (specify)

$T$ raffic offenses

41 Driving while intoxicated

42 Hit and run

43 Reckless driving

44 Driving without a license

45 All other traffic (specify)

Neglect (abuse, desertion, inadequate care, etc.)

51 Abuse

52 All other neglect (specify)

Special proceedings (adoption, consent to marry, etc.)

61 Specify

M. Manne $r$ of Handling

1 Without petition

2 With petition

N. Date of Disposition

O. Disposition

00 Waived to $c$ riminal court

Complaint not substantiated

01 Dismissed: Not proved or found not involved

Complaint substantiated, No transfer of legal custody

11 Dismissed: Warned, adjusted, counselled

12 Held open without further action

13 Probation officer to supervise

14 Referred to another agency or individual for supervision or service 
15 Runaway returned to

16 Other (specify)

Transfer of legal custody to:

21 Public institution for delinquents

22 Other public institution

23 Public agency or department (including court)

24 Private agency or institution

25 Individual

26 Other (specify)

99 Inapplicable - Special Proceedings

P. Prior Traffic and Neglect Referrals

a. Total No. of prior traffic referrals

$\begin{array}{llllll}0 & 1 & 2 & 3 & 4 & 5\end{array}$ or more

b. Total No. of prior neglect referrals

$\begin{array}{llllll}0 & 1 & 2 & 3 & 4 & 5\end{array}$ or more

Q. Diagnostic Services

a. Psychological

b. Psychiatric

c. Medical

d. Social
Need for Diagnostic Services

\begin{tabular}{ccc}
$\begin{array}{c}\text { Indicated } \\
\text { and } \\
\text { provided }\end{array}$ & $\begin{array}{c}\text { Indicated } \\
\text { but not } \\
\text { available }\end{array}$ & $\begin{array}{c}\text { Not indi- } \\
\text { cated }\end{array}$ \\
\cline { 2 - 3 } 1 & 2 & 3 \\
1 & 2 & 3 \\
1 & 2 & 3 \\
1 & 2 & 3
\end{tabular}

R. Estimated Mental Capacity

1 Below average

2 Average
3 Above average

4 Not determined

S. School Attainment \& Adjustment

a. Years of schooling completed:

$\begin{array}{llllllllllllll}00 & 01 & 02 & 03 & 04 & 05 & 06 & 07 & 08 & 09 & 10 & 11 & 12 & \text { or more }\end{array}$

b. Grade placement in relation to age:

1. Retarded

3 Accelerated

2 At expected level

4 Inapplicable (not in school)

c. Serious or persistent school misbehavior

1 Yes 2 No 3 Inapplicable (not in school)

T. Employment and School Status

Not employed

Out of School

In School

Employed

Full time

2

Part time

Inapplicable (pre-school) 
$U$. Length of Residence (of child) in County

1 Under one year

2 One but less than five years

3 Five years or more

V. Living Arrangement of Child

01 With both parents

02 With mother and stepfather

03 With father and stepmother

04 With mother only

05 With father only

06 In horne of relatives

07 In foster family home

08 In institution

09 In independent living a rrangements

10 In other place (specify)

W. Marital Status of Natural Parents

01 Parents married and living together

One or both parents dead:

02 Both dead

03 Father dead

04 Mother dead

Parents separated:

05 Divorced or legally separated

06 Father deserted mother

07 Mother deserted father

08 Other reason (specify)

09 Parents not married to each other

10 Other status (specify)

X. Family Income (Annual)

1 Receiving public assistance at time of referral

Not receiving public assistance at time of referral

2 Under $\$ 3,000$

$3 \$ 3,000$ to $\$ 4,999$

$4 \$ 5,000$ to $\$ 9,999$

$5 \$ 10,000$ and over

6 Unknown

Y. Location of Residence

$1 \quad$ Rural

2 Urban - predominantly residential

3 Urban - predominantly business or industrial area

4 Suburban 
APPENDIX D

INFORMATION ENTERED ON THE MULTNOMAH COUNTY JUVENILE COURT FACE SHEET

Last Name

X-Reference: Div. File Welfare File:
Race

Religion

The following information on each child in family:

First Name Birth Date

Address Birthplace

Birthdate School or occupation Legal Custodian

The following information on each parent (father, mother, stepfather, stepmother, other):
Name
Address
Birth Date
Home \& Business Phone
Occupation
Employer
Social Security Number

\section{Address Change}

Physician \& Medical Plan

Interested Agencies, Relatives, Etc.

Mother's Former Spouses, Dates of Marriage

Father's Former Spouses, Dates of Marriage

The following information on each court contact:

Date

Reason for Referral

Number of Days in Detention

Formal Hearing Date

Disposition Date

Disposition 
APPENDIX E

CODE SHEET \# 1

\begin{tabular}{|c|c|c|}
\hline Column & Code & \\
\hline $\begin{array}{l}1 . \\
2 . \\
3 . \\
4 . \\
5 .\end{array}$ & Six digit case number: if less use 0 in front, & if more take \\
\hline $\begin{array}{l}7 . \\
8 . \\
9 .\end{array}$ & Age to nearest tenth (example 09.2) & No info 999 \\
\hline 10. & $\begin{array}{l}\frac{\text { Sex }}{1 .} \text { Male } \\
\text { 2. Female }\end{array}$ & \\
\hline 11. & $\begin{array}{l}\frac{\text { Race }}{\text { 1. White }} \\
\text { 2. Negro } \\
\text { 3. Indian } \\
\text { 4. Other } \\
\text { 5. Oriental }\end{array}$ & No info 9 \\
\hline 12. & $\begin{array}{l}\frac{\text { Religion }}{\text { 1. Catholic }} \\
\text { 2. Protestant } \\
\text { 3. Jewish } \\
\text { 4. Mormon } \\
\text { 5. None }\end{array}$ & No info 9 \\
\hline $\begin{array}{l}13 . \\
14 .\end{array}$ & $\begin{array}{l}\text { Siblings: Actual number, two digits allowed } \\
\text { (examples: 01, 03, 10) }\end{array}$ & No info 99 \\
\hline $\begin{array}{l}15 . \\
16 .\end{array}$ & $\begin{array}{l}\text { School Attainment: Actual number, two } \\
\text { digits allowed (examples: 09, 12) }\end{array}$ & No info 99 \\
\hline $\begin{array}{l}17 . \\
18 .\end{array}$ & $\begin{array}{l}\text { Status of Natural Parents } \\
\text { 01. Parents married and living together } \\
\text { 02. Both dead } \\
\text { 03. Father dead } \\
\text { 04. Mother dead } \\
\text { 05. Divorced or legally separated } \\
\text { 06. Father deserted mother }\end{array}$ & \\
\hline
\end{tabular}


Code Sheet \#1 (cont'd)

Column Code

07. Mother deserted father

08. Other reason separated or divorced

09. Parents not married to each other

10. Other status

No info 99

19. Family Income

1. PA

2. Under $\$ 3,000$

3. $\$ 3,000-\$ 4,999$

4. $\$ 5,000-\$ 9,999$

5. $\$ 10,000$ and above

No info 9

20. Living Arrangement of Child

21. 01. With both parents

02. With mother and stepfather

03. With father and stepmother

04. Mother only

05. Father only

06. Relatives

07. Foster family home

08. Institution

09. Independent

10. Other

No info 99

22. Days Detained: Actual number, three

23. digits allowed (examples: 008, 021 ,

24. 131)

No info 999

25. Counselor

26. 01 . through 50. (Assign number as counselor's name appears)

27. Recidivism this Year

0 . 0

1. 1

2. 2

3. 3

4. 4

5. 5

6. 6 ormore No info 9

28. Recidivism Prior Years

(same as col. 27)

No info 9 
Code Sheet \#1 (cont'd)

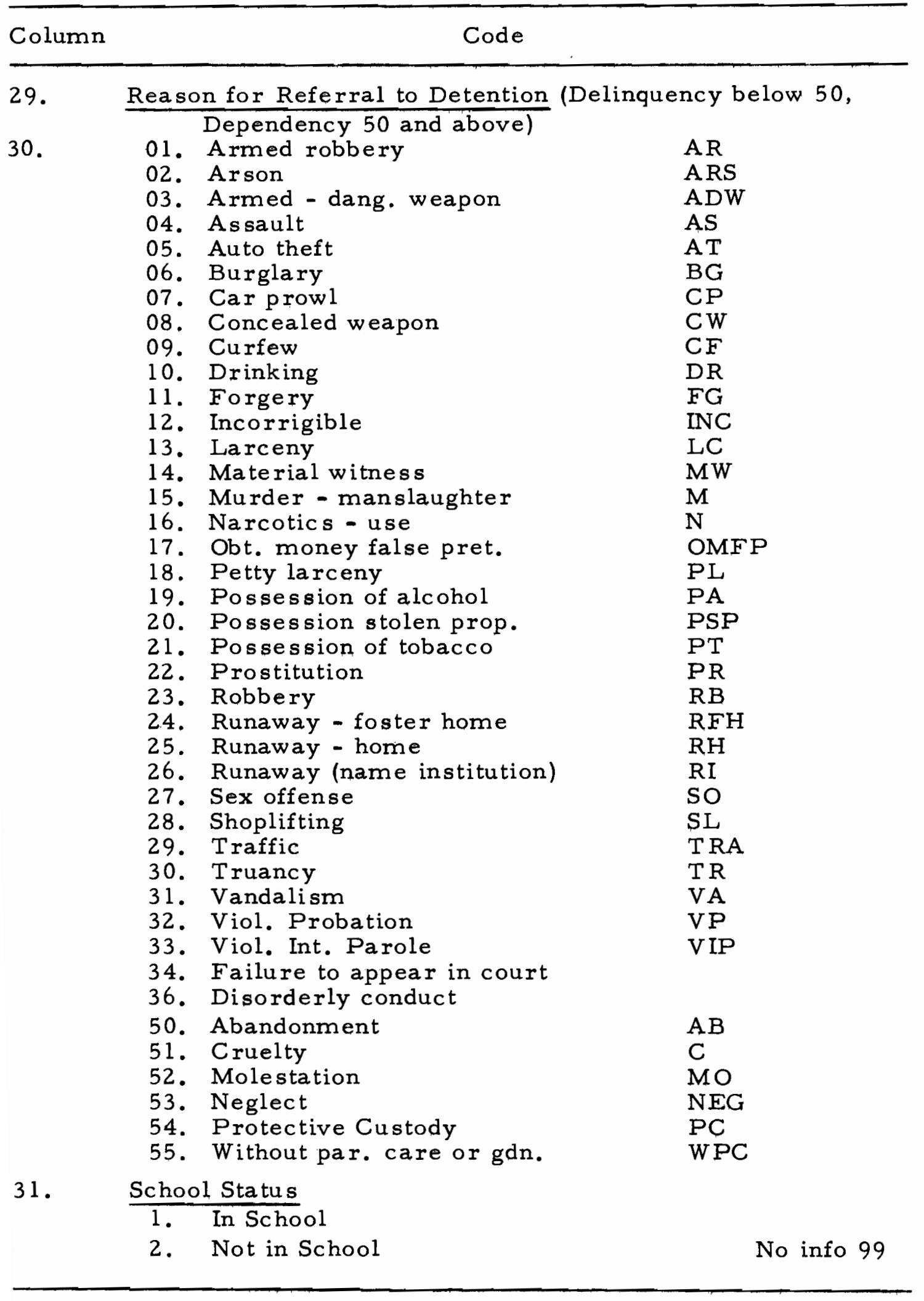


APPENDIX F

CODE SHEET \#2

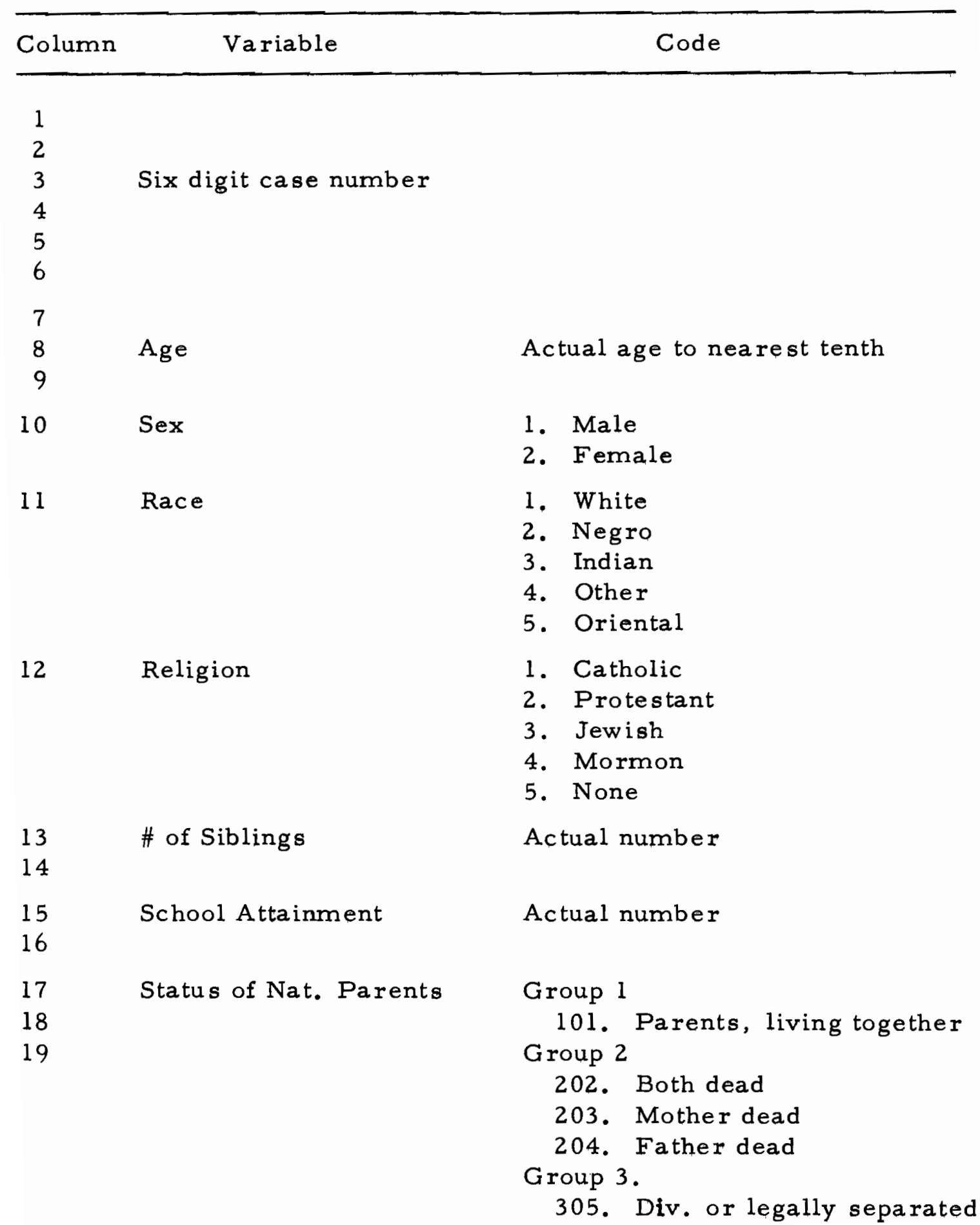


Code Sheet \#2 (cont'd)

\begin{tabular}{|c|c|c|}
\hline Column & Variable & Code \\
\hline & $\begin{array}{l}\text { Status of Nat. Parents } \\
\text { (cont'd) }\end{array}$ & $\begin{array}{l}\text { Group } 4 \\
\text { 406. Father deserted } \\
\text { 407. Mother deserted } \\
\text { 408. Other reas. sep. or div. } \\
\text { 409. Parents not marr. to } \\
\text { each other } \\
\text { 410. Other status }\end{array}$ \\
\hline 20 & Family Income & $\begin{array}{ll}\text { 1. } & \mathrm{Pa} \\
\text { 2. Under } \$ 3,000 \\
\text { 3. } \$ 3,000-\$ 4,999 \\
\text { 4. } \$ 5,000-\$ 9,999 \\
\text { 5. } \$ 10,000 \text { and over }\end{array}$ \\
\hline $\begin{array}{l}21 \\
22 \\
23\end{array}$ & Living Arr. of Child & $\begin{array}{l}\text { Group } 1 \\
\text { 101. With both parents } \\
\text { Group } 2\end{array}$ \\
\hline & & $\begin{array}{l}\text { 202. With ma. and stepfather } \\
\text { 203. With fa. and stepmother } \\
\text { Group } 3 \\
\text { 304. Mother only } \\
\text { 305. Father only } \\
\text { Group } 4 \\
\text { 406. Relatives } \\
\text { 407. Foster family home } \\
\text { 408. Institution } \\
\text { 409. Independent } \\
\text { 410. Other }\end{array}$ \\
\hline $\begin{array}{l}24 \\
25 \\
26\end{array}$ & Days Detained & Actual number (up to three digits) \\
\hline 27 & Recidivism (this year) & $\begin{array}{l}\text { Group } 1 \\
0 . \quad 0 \\
\text { Group } 2 \\
\quad \text { l. } 1 \\
\text { Group } 3 \\
\quad 2.2 \\
\text { Group } 4 \\
\quad 3.3,4,5,6,6+\end{array}$ \\
\hline 28 & Recidivism (prior years) & Groupings same as above \\
\hline
\end{tabular}


Code Sheet \#2 (cont'd)

\begin{tabular}{|c|c|c|}
\hline Column & Variable & Code \\
\hline $\begin{array}{l}29 \\
30 \\
31\end{array}$ & Reason Referred & $\begin{array}{l}\text { Group } 1 \text { - Juvenile Crimes } \\
\text { 109. Curfew } \\
\text { 110. Drinking } \\
\text { 112. Incorrigible } \\
\text { 119. Minor poss. of alcohol } \\
\text { 124. Runaway - foster home } \\
\text { 125. Runaway - home } \\
\text { 126. Runaway - institution } \\
\text { 130. Truancy } \\
\text { Group } 2 \text { - Adult Crimes } \\
\text { 203. Armed dang. weapon } \\
\text { 204. Assault } \\
\text { 205. Auto theft } \\
\text { 206. Burglary } \\
\text { 211. Forgery } \\
\text { 213. Larceny } \\
\text { 216. Narcotics } \\
\text { 217. Obt. money false pretenses } \\
\text { 218. Petty larceny } \\
\text { 220. Possession stolen property } \\
222 \text {. Prostitution } \\
223 \text {. Robbery } \\
227 . \text { Sex offense } \\
228 . \text { Shoplifting } \\
231 \text {. Vandalism } \\
234 . \text { Failure to appear } \\
236 . \text { Disorderly conduct } \\
\text { Group } 3 \text { - Dependency } \\
\text { 354. Protective custody }\end{array}$ \\
\hline 32 & School Status & $\begin{array}{l}\text { 1. In School } \\
\text { 2. Not in School }\end{array}$ \\
\hline $\begin{array}{l}33 \\
34 \\
35\end{array}$ & Placement & $\begin{array}{l}\text { Group } 1 \text { - Return to Parents } \\
001 . \text { Return to parents } \\
\text { Group } 2 \text { - Return to foster, group } \\
\text { homes } \\
\text { 021. Youth Care Center } \\
\text { 022. Foster Home Welfare } \\
\text { 023. Youth Progress } \\
\text { 024. Foster Home Court }\end{array}$ \\
\hline
\end{tabular}


Code Sheet \#2 (cont'd)

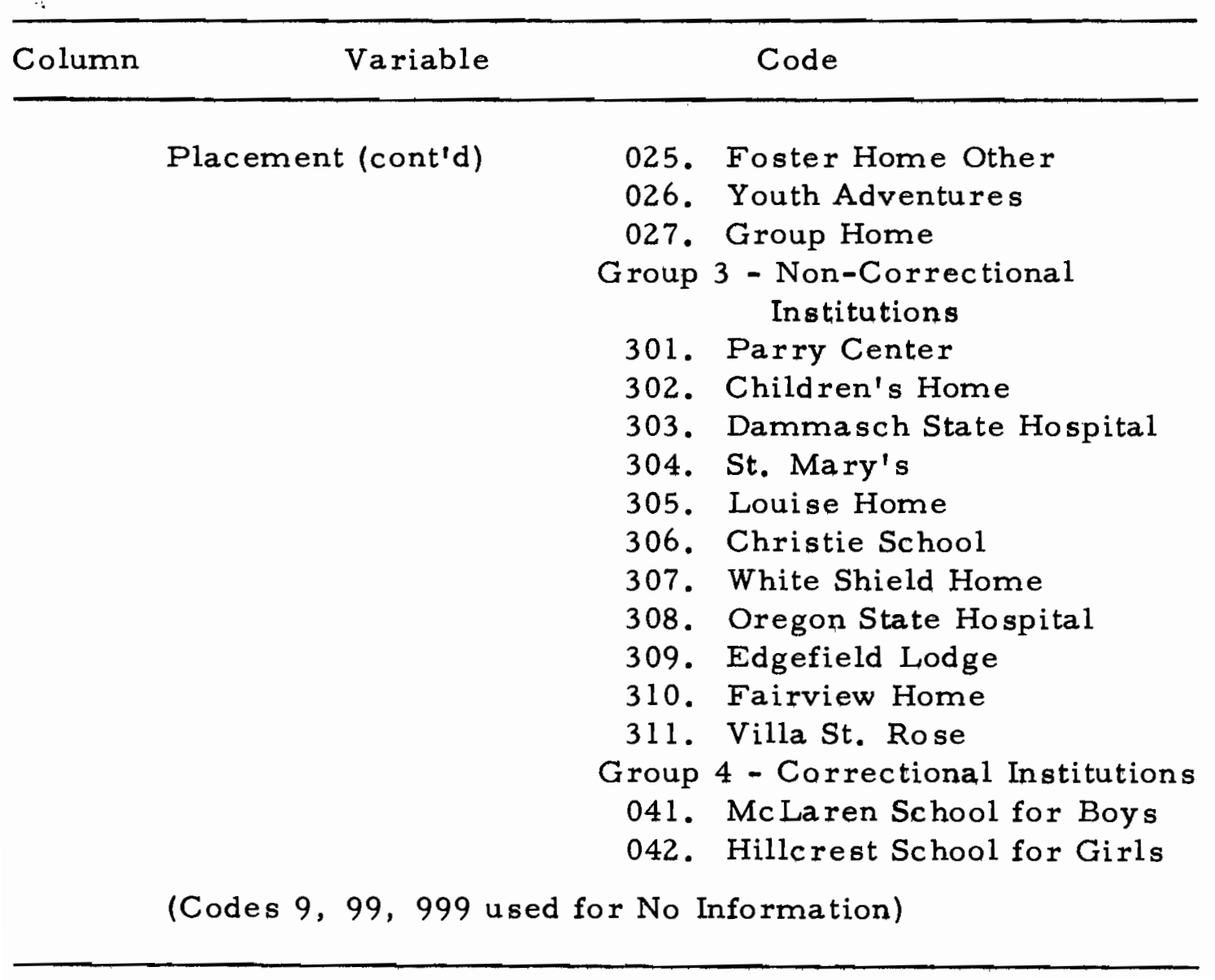


APPENDIX G

FREQUENCY TABULATION AND PERCENTAGE DISTRIBUTION TABLES OF INDEPENDENT VARIABLES LISTED BY GROUP 
TABLE XXVI

FREQUENCY TABULATION AND PERCENTAGE DISTRIBUTION OF INDEPENDENT VARIABLES FOR GROUP I:

RETURN TO PARENTS

\begin{tabular}{|c|c|c|}
\hline Independent Variable & Frequency & $\begin{array}{l}\text { Percentage } \\
\text { Distribution }\end{array}$ \\
\hline
\end{tabular}

SEX

Male

$\begin{array}{ll}48 & 60.00 \\ 32 & 40.00\end{array}$

Total

17.50

Catholic

14

50

62.50

Jewish

0

00.00

Mormon

2

None

02.50

No Info.

Total

12.50

RACE

White

10

$\frac{4}{80}$

$$
05.00
$$

Negro

Indian

Oriental

Other Total

\begin{tabular}{rr}
68 & 85.00 \\
12 & 15.00 \\
0 & 00.00 \\
0 & 00.00 \\
0 & 00.00 \\
\hline 80 &
\end{tabular}

SIBLINGS

0

1

2

3

4

5

6

7

8

9

No Info.

Total

$\overline{\mathbf{x}}=2.77$
10

13

13

19

10

8

3

1

0

2

$\frac{1}{80}$
12.50

16.25

16.25

23.75

12.50

10.00

03.75

01.25

00.00

02.50

01.25 
Table XXVI (cont'd)

\begin{tabular}{lll}
\hline Independent Variable & Frequency & $\begin{array}{c}\text { Percentage } \\
\text { Distribution }\end{array}$ \\
\hline
\end{tabular}

MARITAL STATUS: NAT. PARENTS

Marr. Together

Both dead

Father dead

Mother dead

Div. or separated

Fathe $r$ deserted

Mother deserted

Other reason: sep. or div.

Parents not married

Total

37

0

4

3

31

2

1

1

$\frac{1}{80}$

LIVING ARRANGEMENT OF CHILD

With both parents

Mother and stepfather

Father and stepmothe $r$

Mother only

Fathe $r$ only

Relatives

Foster Home

Institution

Inde pendent

Other

Total
46.25

00.00

05.00

03.75

38. 75

02.50

01.25

01.25

01.25

46. 25

16. 25

07.50

21. 25

02.50

02.50

02.50

00.00

01.25

00.00

61.25

15.00

12. 50

07.50

01.25

02.50

00.00

Total 
Table XXVI (cont'd)

\begin{tabular}{|c|c|c|}
\hline Independent Variable & Frequency & $\begin{array}{l}\text { Percentage } \\
\text { Distribution }\end{array}$ \\
\hline \multicolumn{3}{|l|}{ RECIDIVISM PRIOR YEARS } \\
\hline 0 & 40 & 50.00 \\
\hline 1 & 13 & 16.25 \\
\hline 2 & 5 & 06.25 \\
\hline 3 & 8 & 10.00 \\
\hline 4 & 5 & 06.25 \\
\hline 5 & 5 & 06.25 \\
\hline 6 or more & 4 & 05.00 \\
\hline Total & 80 & \\
\hline \multicolumn{3}{|l|}{ REASON REFERRED } \\
\hline Auto Theft & 6 & 07.50 \\
\hline Burglary & 6 & 07.50 \\
\hline Curfew & 2 & 02.50 \\
\hline Drinking & 1 & 01.25 \\
\hline Incorrigible & 11 & 13.75 \\
\hline Larceny & 1 & 01.25 \\
\hline Narcotics - use & 7 & 08.75 \\
\hline Petty Larceny & 1 & 01.25 \\
\hline Possession of Alcohol & 3 & 03.75 \\
\hline Robbery & 2 & 02.50 \\
\hline Runaway - FH & 1 & 01.25 \\
\hline Runaway - Home & 26 & 32.50 \\
\hline Runaway - Inst. & 1 & 01.25 \\
\hline Sex Offense & 1 & 01.25 \\
\hline Shoplift & 3 & 03.75 \\
\hline Truancy & 2 & 02.50 \\
\hline Vandalism & 1 & 01.25 \\
\hline Failure to Appear & 2 & 02.50 \\
\hline Protective Custody & 3 & 03.75 \\
\hline Total & $\overline{80}$ & \\
\hline \multicolumn{3}{|l|}{ FAMILY INCOME } \\
\hline Public Assistance & 8 & 10.00 \\
\hline Under $\$ 3,000$ & 1 & 01.25 \\
\hline$\$ 3,000-\$ 4,999$ & 5 & 06.25 \\
\hline$\$ 5,000-\$ 9,999$ & 27 & 33.75 \\
\hline$\$ 10,000$ up & 12 & 15.00 \\
\hline Unknown & 27 & 33.75 \\
\hline Total & $\overline{80}$ & \\
\hline
\end{tabular}


Table XXVI (cont'd)

\begin{tabular}{|c|c|c|}
\hline Inde pendent Variable & Frequency & $\begin{array}{l}\text { Percentage } \\
\text { Distribution }\end{array}$ \\
\hline \multicolumn{3}{|l|}{ SCHOOL STATUS } \\
\hline In School & 55 & 68.75 \\
\hline Not in School & 25 & 31.25 \\
\hline Total & 80 & \\
\hline \multicolumn{3}{|l|}{ SCHOOL ATTAINMENT } \\
\hline 4 & 1 & 01.25 \\
\hline 5 & 1 & 01.25 \\
\hline 6 & 3 & 03.75 \\
\hline 7 & 3 & 03.75 \\
\hline 8 & 25 & 31.25 \\
\hline 9 & 13 & 16.25 \\
\hline 10 & 23 & 28.75 \\
\hline 11 & 10 & 12.50 \\
\hline 12 & 1 & 01.25 \\
\hline Total & $\overline{80}$ & \\
\hline \multicolumn{3}{|l|}{$\bar{x}=8.94$} \\
\hline$\overline{\mathrm{x}}=15.88 \mathrm{yrs}$ & 80 & \\
\hline DAYS DETAINED $\quad \overline{\mathrm{x}}=12.46$ & & \\
\hline
\end{tabular}


TABLE XXVII

FREQUENCY TABULATION AND PERCENTAGE DISTRIBUTION OF INDEPENDENT VARIABLES FOR GROUP II: FOSTER HOME CARE

\begin{tabular}{ccr}
\hline Independent Variable & Frequency & $\begin{array}{r}\text { Percenta } \\
\text { Distributio }\end{array}$ \\
\hline SEX & & \\
Male & 16 & 51.61 \\
Female & $\frac{15}{31}$ & 48.38 \\
TELIal & & \\
Catholic & 2 & 06.45 \\
Protestant & 19 & 61.29 \\
Jewish & 0 & 00.00 \\
Mormon & 1 & 03.22 \\
None & 9 & 29.03 \\
Total & 31 &
\end{tabular}

RACE

White

Negro

Indian

Oriental

Other

Total

\begin{tabular}{rr}
25 & 80.64 \\
4 & 12.90 \\
1 & 03.22 \\
0 & 00.00 \\
1 & 03.22 \\
\hline
\end{tabular}

09.67

12. 90

16. 12

22.58

06.45

16.12

06.45

00.00

06.45

03.22

Total

$\frac{1}{31}$

$\overline{\mathbf{x}}=3.2$ 
Table XXVII (cont'd)

\begin{tabular}{|c|c|c|}
\hline Independent Variable & Frequency & $\begin{array}{l}\text { Percentage } \\
\text { Distribution }\end{array}$ \\
\hline \multicolumn{3}{|l|}{ MARITAL STATUS: NAT. PARENTS } \\
\hline Marr. - Together & 9 & 29.03 \\
\hline Both Dead & 1 & 03.22 \\
\hline Father Dead & 1 & 03.22 \\
\hline Mother Dead & 0 & 00.00 \\
\hline Div. or separated & 14 & 45.16 \\
\hline Father deserted & 1 & 03.22 \\
\hline Mother deserted & 2 & 06.45 \\
\hline Other reason: sep. or div. & 1 & 03.22 \\
\hline $\begin{array}{l}\text { Parents not married } \\
\text { Total }\end{array}$ & $\frac{2}{31}$ & 06.45 \\
\hline \multicolumn{3}{|l|}{ LIVING ARRANGEMENT OF CHILD } \\
\hline With both parents & 7 & 22.58 \\
\hline Mother and stepfather & 2 & 06.45 \\
\hline Father and stepmothe $r$ & 2 & 06.45 \\
\hline Mothe $\mathrm{r}$ only & 4 & 12.90 \\
\hline Father only & 1 & 03.22 \\
\hline Relatives & 1 & 03.22 \\
\hline Foster home & 11 & 35.48 \\
\hline Institution & 0 & 00.00 \\
\hline Inde pendent & 0 & 00.00 \\
\hline Other & 3 & 09.67 \\
\hline Total & $\overline{31}$ & \\
\hline \multicolumn{3}{|l|}{ RECIDIVISM THIS YEAR } \\
\hline 0 & 19 & 61.29 \\
\hline 1 & 6 & 19.25 \\
\hline 2 & 2 & 06.45 \\
\hline 3 & 2 & 06.45 \\
\hline 4 & 2 & 06.45 \\
\hline 5 & 0 & 00.00 \\
\hline $\begin{array}{c}6 \text { or more } \\
\text { Total }\end{array}$ & $\frac{0}{31}$ & 00.00 \\
\hline
\end{tabular}


Table XXVII (cont'd)

\begin{tabular}{|c|c|c|}
\hline Independent Variable & Frequency & $\begin{array}{l}\text { Percentage } \\
\text { Distribution }\end{array}$ \\
\hline
\end{tabular}

RECIDIVISM PRIOR YEARS

0
1
2
3
4
5
6 or more
Total

$\begin{array}{rr}14 & 45.16 \\ 7 & 22.58 \\ 2 & 06.45 \\ 1 & 03.22 \\ 2 & 06.45 \\ 3 & 09.67 \\ 2 & 06.45\end{array}$

REASON REFERRED

$\begin{array}{lll}\text { Auto Theft } & 1 & 03.22 \\ \text { Forgery } & 1 & 03.22 \\ \text { Incorrigible } & 7 & 22.58 \\ \text { Narcotics - use } & 1 & 03.22 \\ \text { Poss. Stolen Property } & 1 & 03.22 \\ \text { Prostitution } & 1 & 03.22 \\ \text { Runaway - FH } & 5 & 16.12 \\ \text { Runaway - Home } & 6 & 19.35 \\ \text { Shoplift } & 1 & 03.22 \\ \text { Truancy } & 1 & 03.22 \\ \text { Protective Custody } & 6 & 19.35 \\ \quad \text { Total } & 31 & \end{array}$

FAMILY INCOME

$\begin{array}{lll}\text { Public Assistance } & 7 & 22.58\end{array}$

$\begin{array}{lll}\text { Under } \$ 3,000 & 0 & 00.00\end{array}$

$\$ 3,000-\$ 4,999 \quad 3 \quad 09.67$

$\$ 5,000-\$ 9,999 \quad 8 \quad 25.80$

$\$ 10,000$ up $\quad 2 \quad 06.45$

$\begin{array}{lll}\text { Unknown } & 11 & 35.48\end{array}$

Total $\quad \frac{11}{31}$

SCHOOL STATUS

In School

Not In School

Total

$\begin{array}{rl}30 & 96.77 \\ \frac{1}{31} & 03.22\end{array}$


Table XXVII (cont'd)

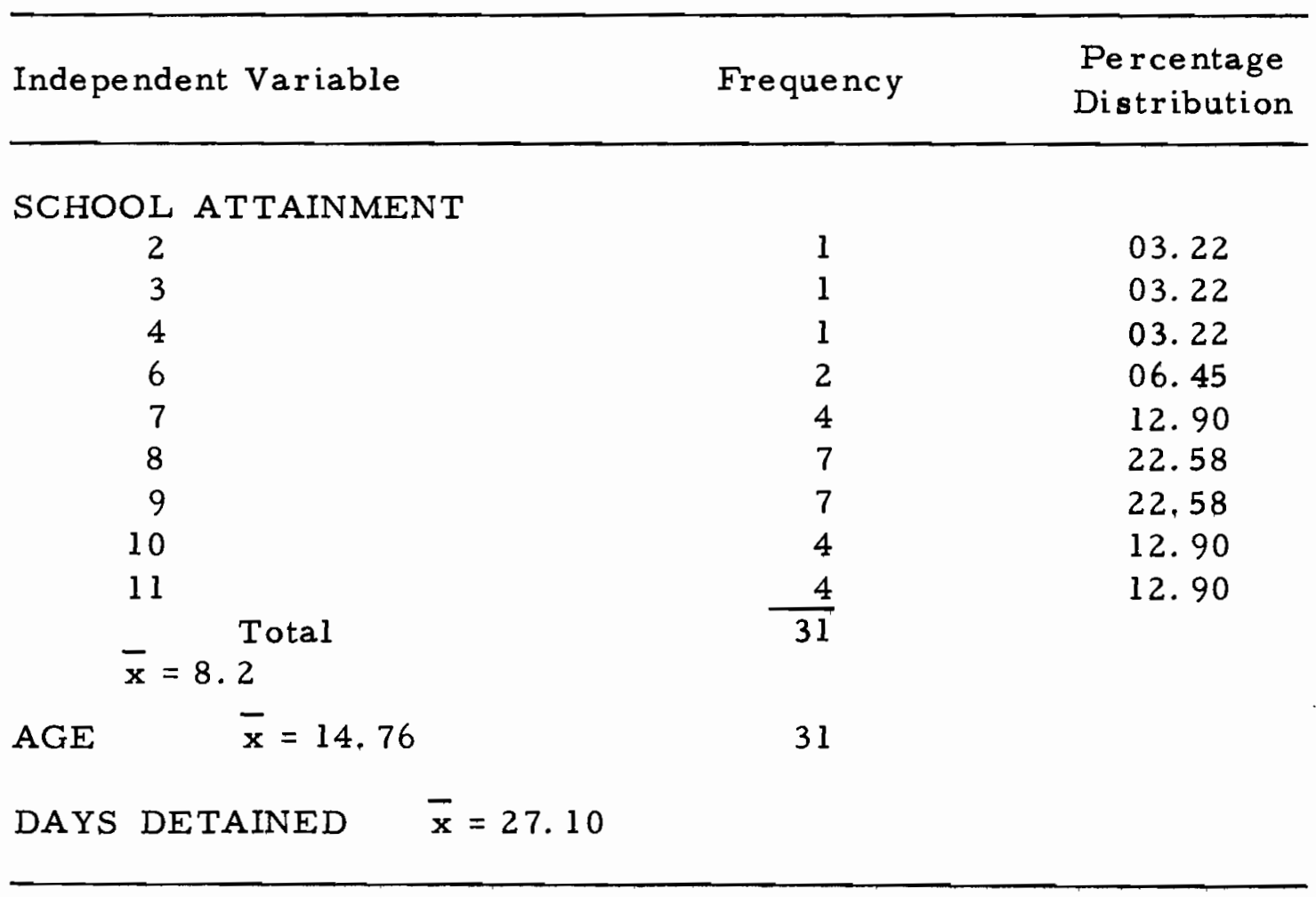


TABLE XXVIII

FREQUENCY TABULATION AND PERCENTAGE DISTRIBUTION OF INDEPENDENT VARIABLES FOR GROUP III: TREATMENT INSTITUTIONS

\begin{tabular}{ccr}
\hline Independent Variable & Frequency & $\begin{array}{r}\text { Percenta } \\
\text { Distributi }\end{array}$ \\
SEX $\quad$ Male & 10 & \\
Female & $-\frac{22}{32}$ & 31.25 \\
Total & & 68.75 \\
RELIGION & 3 & \\
Catholic & 22 & 09.37 \\
Protestant & 0 & 67.35 \\
Jewish & 2 & 00.00 \\
Mormon & 5 & 06.25 \\
None & 32 & 15.62
\end{tabular}

RACE

White

Negro

Indian

Oriental

Other

Total

$\begin{array}{rr}30 & 93.75 \\ 2 & 06.25 \\ 0 & 00.00 \\ 0 & 00.00 \\ 0 & 00.00\end{array}$

SIB LINGS

0
1
2
3
4
5
6
7
8
No info.
$\bar{x}=3.06$

03. i2

18. 75

03.12

15.62

15.62

15.62

18. 75

16.25

00.00

03.12

$\bar{x}=3.06$ 
Table XXVIII (cont'd)

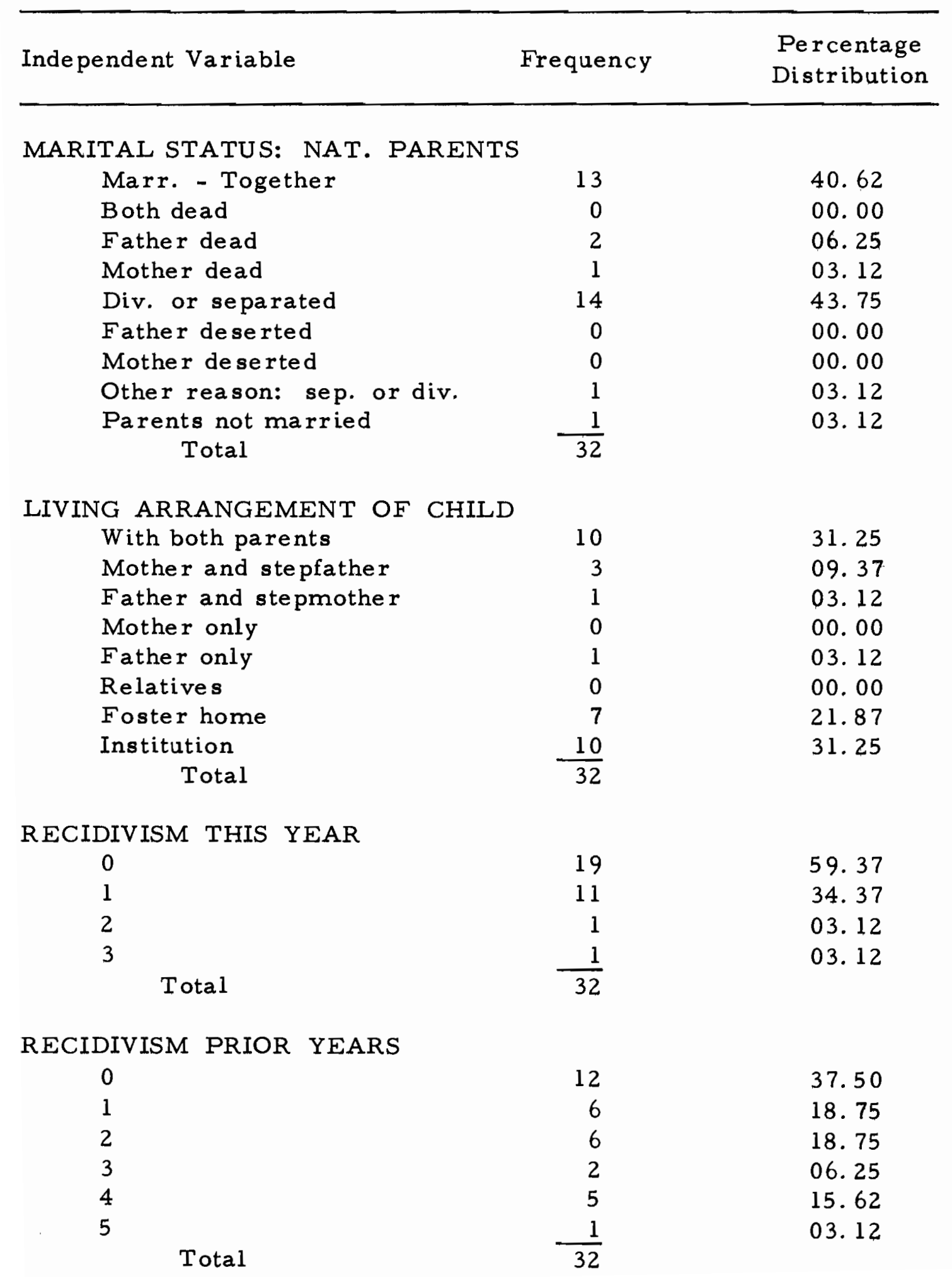


Table XXVIII (cont'd)

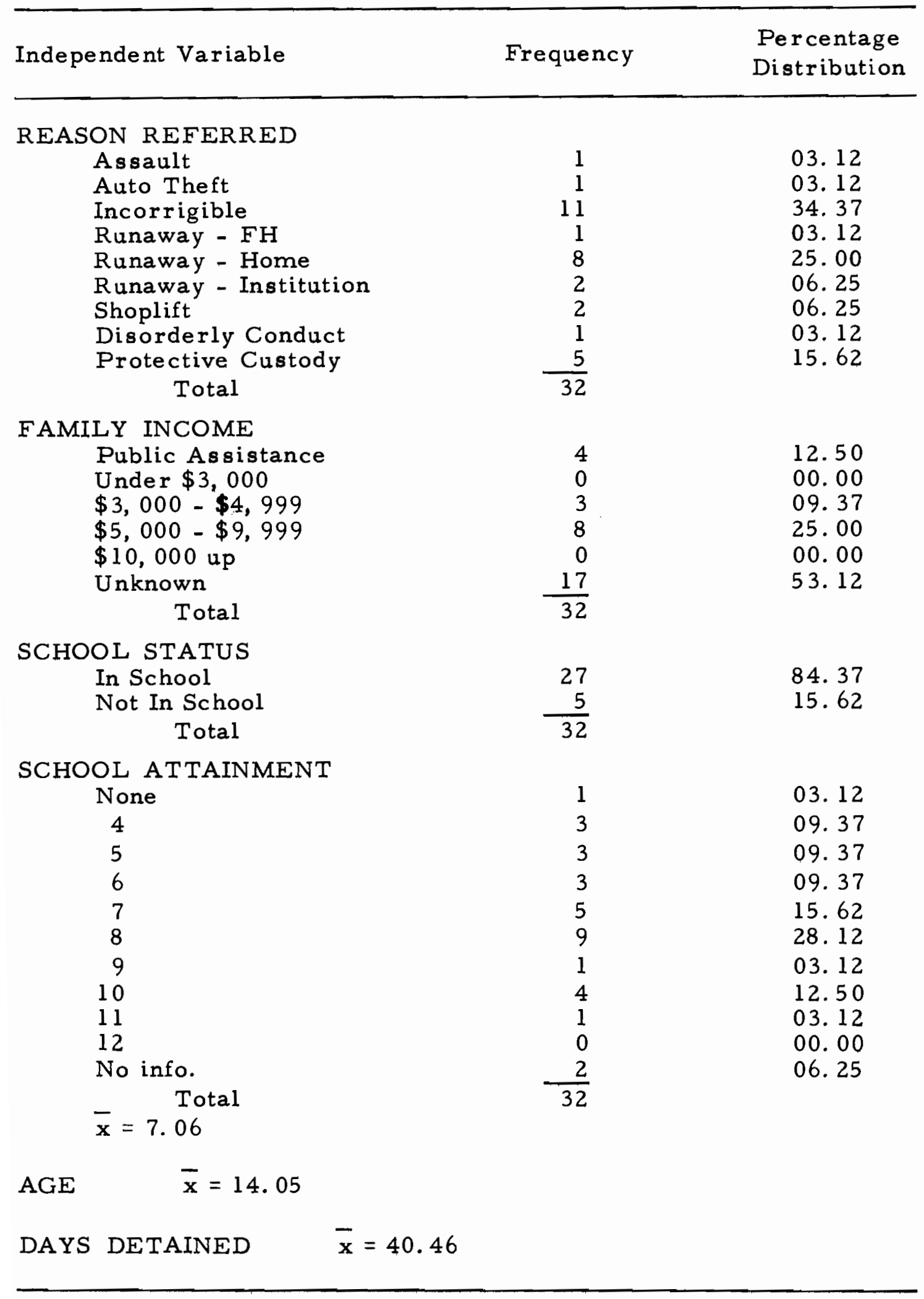


TABLE XXIX

FREQUENCY TABULATION AND PERCENTAGE DISTRIBUTION OF INDEPENDENT VARIABLES FOR GROUP IV: CORRECTIONAL INSTITUTIONS

\begin{tabular}{|c|c|c|}
\hline Independent Variable & Frequency & $\begin{array}{l}\text { Percentage } \\
\text { Distribution }\end{array}$ \\
\hline \multicolumn{3}{|l|}{ SEX } \\
\hline Male & 16 & 53.33 \\
\hline Female & 14 & 46.66 \\
\hline Total & 30 & \\
\hline \multicolumn{3}{|l|}{ RELIGION } \\
\hline Catholic & 2 & 06.66 \\
\hline Protestant & 16 & 53.33 \\
\hline Jewish & 0 & 00.00 \\
\hline Mormon & 0 & 00.00 \\
\hline None & 12 & 40.00 \\
\hline Total & 30 & \\
\hline \multicolumn{3}{|l|}{$\mathrm{RACE}$} \\
\hline White & 22 & 73.33 \\
\hline Negro & 7 & 23.33 \\
\hline Indian & 1 & 03.33 \\
\hline Oriental & 0 & 00.00 \\
\hline Other - & 0 & 00.00 \\
\hline Total & 30 & \\
\hline \multicolumn{3}{|l|}{ SIBLINGS } \\
\hline 0 & 2 & 06.66 \\
\hline 1 & 3 & 10.00 \\
\hline 2 & 4 & 13.33 \\
\hline 3 & 7 & 23.33 \\
\hline 4 & 4 & 13.33 \\
\hline 5 & 4 & 13.33 \\
\hline 6 & 4 & 13.33 \\
\hline 8 & 1 & 03.33 \\
\hline 14 & 1 & 03.33 \\
\hline $\bar{x}=3.80$ & $\overline{30}$ & \\
\hline
\end{tabular}


Table XXIX (cont'd)

\begin{tabular}{|c|c|c|}
\hline Independent Variable & Frequency & $\begin{array}{l}\text { Percentage } \\
\text { Distribution }\end{array}$ \\
\hline \multicolumn{3}{|c|}{ MARITAL STATUS: NAT. PARENTS } \\
\hline Marr. - Together & 8 & 26.66 \\
\hline Fathe $r$ dead & 2 & 06.66 \\
\hline Div. or Separated & 17 & 56.66 \\
\hline Parents not married & 1 & 03.33 \\
\hline Other & 2 & 06.66 \\
\hline Total & 30 & \\
\hline \multicolumn{3}{|c|}{ LIVING ARRANGEMENT OF CHILD } \\
\hline With both parents & 6 & 20.00 \\
\hline Mother and stepfather & 5 & 16.66 \\
\hline Fathe $r$ and stepmothe $r$ & 0 & 00.00 \\
\hline Mother only & 6 & 20.00 \\
\hline Father only & 0 & 00.00 \\
\hline Relatives & 2 & 06.66 \\
\hline Foster home & 5 & 16.66 \\
\hline Institution & 4 & 13.33 \\
\hline Independent & 1 & 03.33 \\
\hline Other & 1 & 03.33 \\
\hline Total & 30 & \\
\hline \multicolumn{3}{|l|}{ RECIDIVISM THIS YEAR } \\
\hline 0 & 13 & 43.33 \\
\hline 1 & 6 & 20.00 \\
\hline 2 & 2 & 06.66 \\
\hline 3 & 5 & 16.66 \\
\hline 4 & 4 & 13.33 \\
\hline 5 & 0 & 00.00 \\
\hline 6 & 0 & 00.00 \\
\hline Total & 30 & \\
\hline \multicolumn{3}{|l|}{ RECIDIVISM PRIOR YEARS } \\
\hline 0 & 7 & 23.33 \\
\hline 1 & 2 & 06.66 \\
\hline 2 & 3 & 10.00 \\
\hline 3 & 3 & 10.00 \\
\hline 4 & 0 & 00.00 \\
\hline 5 & 7 & 23.33 \\
\hline 6 or more & 8 & 26.66 \\
\hline Total & 30 & \\
\hline
\end{tabular}


Table XXIX (cont'd)

\begin{tabular}{lll}
\hline Independent Variable & Frequency & $\begin{array}{c}\text { Percentage } \\
\text { Distribution }\end{array}$ \\
\hline
\end{tabular}

REASON REFERRED

Armed, dang. weapon

Auto Theft

03.33

Burglary

Incorrigible

Obt. \& False

Runaway - FH

1

06.66

10.00

16.66

03.33

10.00

Runaway - Institution

10.00

Sex Offense

06.66

Shoplift

10.00

Vandalism

03.33

Protective Custody

06.66

Runaway - Home

Total

13.33

FAMILY INCOME

Public Assistance

Under $\$ 3,000$

$\$ 3,000-\$ 4,999$

$\$ 5,000-\$ 9,999$

$\$ 10,000$ up

Unknown

Total

10.00

03.33

00.00

33.33

10. 00

43. 33

$\frac{13}{30}$

SCHOOL STATUS

In School

Not In School

Total

20

$-10$

SCHOOL ATTAINMENT

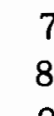

8

9

10

- Total

$\bar{x}=8.53$

$A G E$

$\overline{\mathbf{x}}=15.40$

30
66.66

33.33

16.66

30.00

36.66

16.66

DAYS DETAINED $\quad \overline{\mathrm{x}}=18.26$ 
APPENDIX H

TABLES OF DISCRIMINANT FUNCTION WITH GROUP MEANS 
TABLE XXX

DISCRIMINANT FUNCTION OF FIVE VARIABLES WITH GROUP MEANS

\begin{tabular}{|c|c|c|c|c|c|c|c|c|c|}
\hline \multirow[b]{3}{*}{ Variable } & \multicolumn{8}{|c|}{ Placement Group } & \multirow{3}{*}{$\begin{array}{c}\text { Common } \\
\text { Mean }\end{array}$} \\
\hline & \multicolumn{2}{|r|}{ I } & \multicolumn{2}{|c|}{ II } & \multicolumn{2}{|c|}{ III } & \multicolumn{2}{|c|}{ IV } & \\
\hline & Mean & Coeff. & Mean & Coeff. & Mean & Coeff. & Mean & Coeff. & \\
\hline Reason Referred & 1.46 & 3.962 & 1.60 & 4. 362 & 1. 40 & 3.775 & 1.53 & 4. 122 & 1. 49 \\
\hline \multicolumn{10}{|l|}{ Recidivism } \\
\hline Prior Years & 1.19 & -0.489 & 1.17 & -0.405 & 1.40 & -2.220 & 2. 07 & 0.080 & 1. 38 \\
\hline School Status & 1. 30 & 4.234 & 1.03 & 2.839 & 1.17 & 3.811 & 1.33 & 4.523 & 1.24 \\
\hline $\begin{array}{c}\text { Marital Status } \\
\text { of Natural } \\
\text { Parents }\end{array}$ & 2. 04 & 3.675 & 2.50 & 3.961 & 2.10 & 3.537 & 2.50 & 4.077 & 2.21 \\
\hline Age & 15.88 & 5.836 & 14. 77 & 5.534 & 14.05 & 5.171 & 15.41 & 5.636 & 15.28 \\
\hline Constant & & -55.438 & & -50.541 & & -44.762 & & -54.772 & \\
\hline
\end{tabular}


TABLE XXXI

DISCRIMINANT FUNCTION OF SEVEN VARIABLES WITH GROUP MEANS

\begin{tabular}{|c|c|c|c|c|c|c|c|c|c|}
\hline \multirow[b]{3}{*}{ Variable } & \multicolumn{8}{|c|}{ Placement Group } & \multirow{3}{*}{$\begin{array}{l}\text { Common } \\
\text { Mean }\end{array}$} \\
\hline & \multicolumn{2}{|c|}{ I } & \multicolumn{2}{|c|}{$\amalg$} & \multicolumn{2}{|c|}{ III } & \multicolumn{2}{|c|}{ IV } & \\
\hline & Mean & Coeff. & Mean & Coeff. & Mean & Coeff. & Mean & Coeff. & \\
\hline Religion & -0.47 & -0.373 & -0.57 & -0.715 & -0.63 & -0.940 & -0.47 & -0.618 & -0.51 \\
\hline $\begin{array}{l}\text { Living Arrange- } \\
\text { ment }\end{array}$ & 1.19 & -0.401 & 1.17 & -0.402 & 1.40 & -0.236 & 2.07 & 0.125 & 1. 38 \\
\hline Recidivism & & & & & & & & & \\
\hline Prior Years & 1.89 & -0.688 & 2.80 & 0.191 & 2.70 & 0.432 & 2.67 & -0.221 & 2. 33 \\
\hline Reason Referred & 1.46 & 4.009 & 1.60 & 4. 279 & 1.40 & 3.647 & 1.53 & 4.095 & 1.49 \\
\hline School Status & 1.30 & 4.462 & 1.03 & 2.935 & 1.17 & 3.896 & 1.33 & 4.693 & 1.24 \\
\hline Age & 15.88 & 5.834 & 14.77 & 5.499 & 14.05 & 5.121 & 15.41 & 5.614 & 15.28 \\
\hline $\begin{array}{l}\text { Marital Status of } \\
\text { Natural Parents }\end{array}$ & 2.04 & 4.221 & 2.50 & 3.908 & 2.10 & 3.336 & 2.50 & 4.313 & 2.21 \\
\hline Constant & & -55.656 & & $-50,672$ & & -45.030 & & -54.885 & \\
\hline
\end{tabular}


TABLE XXXII

DISCRIMINANT FUNCTION OF FIVE VARIABLES WITH GROUP MEANS

\begin{tabular}{|c|c|c|c|c|c|c|c|c|c|}
\hline \multirow[b]{3}{*}{ Variable } & \multicolumn{8}{|c|}{ Placement Group } & \multirow{3}{*}{$\begin{array}{c}\text { Common } \\
\text { Mean }\end{array}$} \\
\hline & \multicolumn{2}{|r|}{ I } & \multicolumn{2}{|c|}{ II } & \multicolumn{2}{|c|}{ III } & \multicolumn{2}{|c|}{ IV } & \\
\hline & Mean & Coeff. & Mean & Coeff. & Mean & Coeff. & Mean & Coeff. & \\
\hline Age & 15.88 & 11.419 & 14.77 & 10.876 & 14.05 & 11.215 & 15.41 & 11.284 & 15.28 \\
\hline $\begin{array}{c}\text { Number of } \\
\text { Siblings }\end{array}$ & 2.77 & 0.938 & 3.20 & 0.954 & 3.07 & 0.908 & 3.80 & 1.137 & 3.08 \\
\hline $\begin{array}{l}\text { School Attain- } \\
\text { ment }\end{array}$ & 8.96 & -6.795 & 8.13 & -6.437 & 7.28 & -7.090 & 8.53 & -6.787 & 8.43 \\
\hline Family Income & 3.64 & 1.274 & 2.90 & 0.676 & 3.00 & 0.861 & 3.53 & 1. 278 & 3. 38 \\
\hline Days Detained & 12. 35 & 0.075 & 26.32 & 0.115 & 40.16 & 0.149 & 18.27 & 0.088 & 21.02 \\
\hline Constant & & -64.346 & & -57.987 & & -59.451 & & -63.183 & \\
\hline
\end{tabular}


TABLE XXXIII

DISCRIMINANT FUNCTION OF EIGHT VARIABLES WITH GROUP MEANS

\begin{tabular}{|c|c|c|c|c|c|c|c|c|c|}
\hline \multirow[b]{3}{*}{ Variable } & \multicolumn{8}{|c|}{ Placement Group } & \multirow{3}{*}{$\begin{array}{l}\text { Common } \\
\text { Mean }\end{array}$} \\
\hline & \multicolumn{2}{|c|}{ I } & \multicolumn{2}{|r|}{$\amalg$} & \multicolumn{2}{|c|}{ III } & \multicolumn{2}{|c|}{ IV } & \\
\hline & Mean & Coeff. & Mean & Coeff. & Mean & Coeff. & Mean & Coeff. & \\
\hline Age & 15.88 & 7.960 & 14.77 & 7.736 & 14.05 & 7.427 & 15.41 & 7.867 & 15.28 \\
\hline Sex & 1.40 & 4.737 & 1. 48 & 4.849 & 1.69 & 6.018 & 1.47 & 5.167 & 1.48 \\
\hline Race & 1.15 & 8.565 & 1.29 & 8.998 & 1.06 & 7. 737 & 1.30 & 9.100 & 1.18 \\
\hline $\begin{array}{c}\text { Number of } \\
\text { Siblings }\end{array}$ & 3.12 & 0.813 & 3.51 & 0.855 & 3.68 & 0.977 & 4.05 & 1.068 & 3.45 \\
\hline $\begin{array}{l}\text { School Attain- } \\
\text { ment }\end{array}$ & 8.96 & -3.926 & 8.13 & -3.878 & 7.28 & -3.992 & 8.53 & -4.012 & 8.43 \\
\hline Family Income & 3.59 & 2.148 & 2.90 & 1.671 & 3.00 & 1.860 & 3.53 & 2.258 & 3.35 \\
\hline Days Detained & 12.35 & 0.073 & 26.32 & 0.111 & 40.16 & 0.140 & 18.27 & 0.086 & 21.02 \\
\hline School Status & 1.31 & 3.939 & 1.03 & 2.521 & 1.16 & 3.647 & 1.33 & 4.200 & 1.24 \\
\hline Constant & & -62.015 & & -57.330 & & -55.625 & & -62.924 & \\
\hline
\end{tabular}

